Being Irish on the Prairies:

Repertoire, performance, and environment in oral history narratives of Winnipeg Irish Canadians

by

\title{
Kathryn Boschmann
}

A thesis submitted to the Faculty of Graduate and Postdoctoral

Affairs in partial fulfillment of the requirements

for the degree of

Master of Arts

in

History

Carleton University

Ottawa, Ontario

(C) 2015

Kathryn Boschmann 


\begin{abstract}
This thesis applies Diana Taylor's concept of repertoire to oral history interviews with ten first generation Irish Canadians living in Winnipeg who emigrated between 1957 and 2012. It argues that traditional performances, such as music and dance, have acquired a provenance with particular histories. This has made them both meaningful and politically contentious expressions of Irish identity. Memory tensions emerged when the performances were integrated into a new repertoire in Canada. Taylor's concept is modified and applied to embodied encounters with landscape and weather. As experiences of a new place are incorporated into a spatial repertoire, they become infused with emotional significance, and emigrants' stories about visiting Ireland, surviving Manitoban winters, or driving across flat prairie spaces, communicate feelings of displacement and belonging. Accompanying this thesis is a website which further explores emotional memories in these interviews through an audio exhibit (www.beingirishontheprairies.ca).
\end{abstract}




\section{Acknowledgements}

First and foremost, I must thank the individuals who agreed to participate in this project as interviewees. Without their willingness and generosity, this project would not have been possible and it was truly a privilege to listen to, record, and analyze their stories.

I owe a huge debt of gratitude for my supervisors, Dr. Joanna Dean and Dr. Bruce Elliott. Their support and insight have been invaluable throughout this process and I have learned so much under their guidance. I would also like to thank the faculty and staff at the History Department whose help has been invaluable. I am particularly thankful for the mentorship I received from Dr. David Dean, Dr. James Opp, and Dr. John Walsh both in and outside of the classroom. Thank you also to Joan White whose administrative assistance and advice has been so helpful. I am also grateful for the time and thoughtful comments I received from my examiners Dr. Marilyn Barber, Dr. Steven High, and Dr. James Opp.

I have valued the technical help I received from Shawn Anctil, Bethany Berard, and Digital History at Carleton Workshop and the photographs contributed by Susie Fisher and Tom Naughten which were used as visuals for the website.

Thank you to staff and associates at The Mellon Centre for Migration Studies, particularly Dr. Patrick Fitzgerald, Dr. Johanna Devlin Trew, and Christine Johnson. While their interviews do not feature in this thesis, their insight and advice came at a formative stage in this project and were central in its development. Their generosity and graciousness made this visit a highlight of my trip and I hope to return to their interviews in the future. I also appreciated the time Sharon Slater took to show me around the beautiful city of Limerick and share her knowledge and experience concerning Irish migration and heritage tourism. I also benefitted from the workshops, resources, and support of the Oral History Centre at the University of Winnipeg.

I would also like to express my gratitude towards the Social Science and Humanities Research Council of Canada (SSHRC), Ontario Graduate Scholarship (OGS) program, and the Shannon Fund of the Carleton Centre for the History of Migration, Digital History at Carleton Workshop (DH@CWorks), and the Faculty of Arts and Social Sciences (FASS) for funding this research as well as its dissemination through conference presentations.

Finally, I cannot begin to express my gratitude for my friends and family who have been constant supports throughout this process. Thank you to my friends and peers in the department who have lent a friendly ear and pushed my thinking. I have learned so much from you and you have made these two years a joyful experience. I must also thank my family who have been so patient, loving, and supportive. I want to especially thank my parents, Janet and Ewald Boschmann. Thank you for listening while I talked through this project, reading drafts, feeding me during the most hectic writing periods, and for the constant emotional support you offered. I am and will be ever grateful. 


\section{Table of Contents}

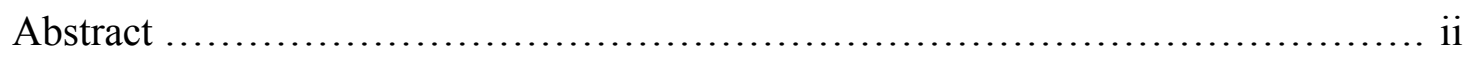

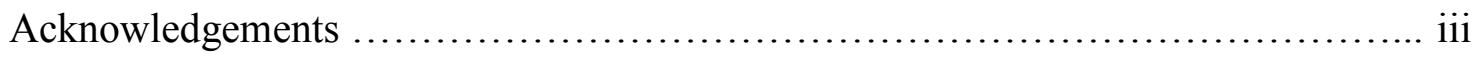

Table of Contents ............................................................. iv

List of Appendices .............................................................. vi

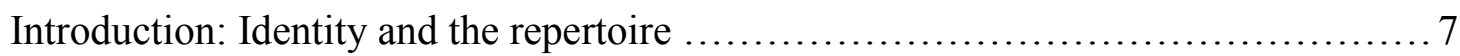

Chapter One: "Some cultural thing to hang my hat on": Performance and memory among Irish Canadians in Winnipeg .................................................. 25

1.1 National narratives, multiculturalism, and migrant memories .............. 30

1.2 Irish nationalism, culture, and the state .............................. 36

1.3 Leaving the Republic: Narratives from 1970s Irish immigrants .............43

1.4 A new immigrant cohort addresses the politics of difference ............... 55

1.5 Before cultural revival and multiculturalism: 1950s Irish immigrants ........ 64

1.6 A troubled repertoire: The narratives of Northern Irish immigrants .......... 74

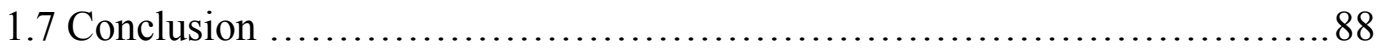

Chapter Two: "The rest is sky": Landscape, weather, and identity in Ireland and

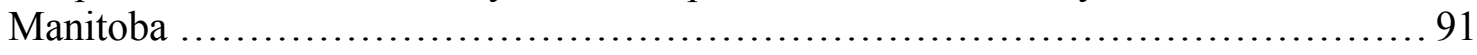

2.1 Bodies and environments: Theoretical framework .......................93

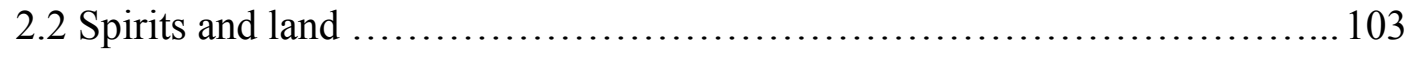

2.3 Locating home: Leaving Ireland and imagining Canada ................... 111

2.4 The winters of our discontent: Weather in Manitoba and Ireland ...................115

2.5 Gaining perspective: Movement and place …........................ 120

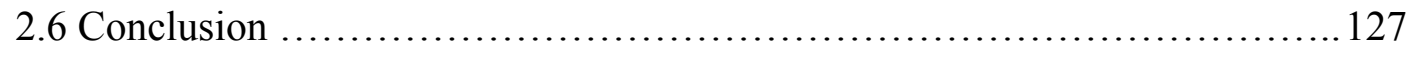


Conclusion

Bibliography

Appendices . .144 


\section{List of Appendices}

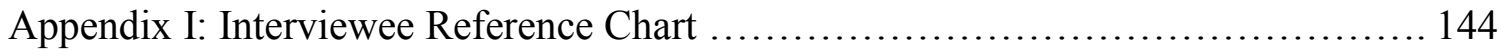

Appendix II: Ethics Clearance Forms ......................................... 145

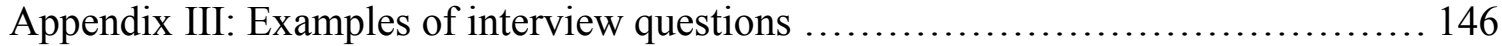




\section{Introduction: Identity and the repertoire}

The historian Greg Dening wrote that "History is not the past. It is the past transformed into something else, story." ${ }^{1}$ Stories are the historian's business: we read them, listen to them, think about them, and write them. In the summer of 2014, I had the pleasure and honour to listen to and record the stories of ten first generation Irish Canadians living in Winnipeg, Manitoba. ${ }^{2}$ These individuals graciously agreed to sit down with me and discuss their experiences of migration, thoughts on Irish history, opinions on cultural activities, and more. The interviews are not their whole story. Rather, they highlight selected moments from their lives captured in a conversation between two people that took place at a particular moment. It is now my work to weave these stories together and tell another.

The questions I ask have evolved over time but were all rooted in the same interest: the connection between memory and identity. How do migrants remember and how is personal and collective memory negotiated in the light of new and changing physical and cultural contexts? How do these memories affect how we think and behave in the present? I examine these questions by drawing and expanding on performance theorist Diana Taylor's concept of repertoire. She is interested in embodied ways of communicating and draws attention to actions that, through repetition, acquire meanings for the participants. These actions then convey that the actors belong to certain communities and identify with certain pasts. She calls this mode of collecting and telling history the repertoire and compares it to traditional western formats of history telling

\footnotetext{
${ }^{1}$ Greg Dening, Performances (Chicago: The University of Chicago Press, 1996), 34.

${ }^{2}$ All interview recordings and transcripts are in possession of the author. I am using Irish Canadians as a blanket term for sake of simplicity. It is worth noting, however, that one interviewee, Greg McVicker, does not have (nor particularly want) Canadian citizenship and would probably identify primarily as Irish.
} 
which are found primarily in physical archives. While the archive is based in written documents and material objects, the repertoire is an inventory of embodied actions of individuals identifying with particular communities. This includes but is not limited to oral traditions, dances, songs, ways of speaking, gestures, food ways, and so on. ${ }^{3}$ This concept provides a useful structure to analyze the ways in which people retain, reconstruct, and share knowledge of the past.

The people I spoke with are part of the Irish diaspora which has a long and global history. ${ }^{4}$ A number of scholars have written histories of the Irish in Canada but these have tended to focus on the $19^{\text {th }}$ century migrations and on the eastern and central regions of the country. ${ }^{5}$ Angèle Smith observes a continued gap in historiography concerning Irish Canadians in the west. She offers a comparison with the experiences and narratives of Irish life in the urban space of Toronto and rural British Columbia in the 1800s. While she finds the Irish were (and are) certainly present in the west, they are conspicuously absent from the grander narrative of Canada's western regions. Smith suggests that this difference is due to the ways in which both Canada's wilderness and notions about Irish identity were imagined in this period. The narrative of Irish immigrants in Canada as urban, impoverished Catholics has overshadowed the stories of the Irish in the west and

\footnotetext{
${ }^{3}$ Diana Taylor, The Archive and the Repertoire: Performing Cultural Memory in the Americas (Durham, NC: Duke University Press, 2003), 2-5, 16-26.

${ }^{4}$ Donald Akenson, The Irish Diaspora: A Primer (Toronto: P.D. Meany, 1993); Patrick Fitzgerald and Brian Lambkin, Migration in Irish History, 1607-2007 (Hampshire and New York: Palgrave Macmillan, 2008); Joanne Devlin Trew, Leaving the North: Migration and Memory, Northern Ireland 1921-2011 (Liverpool: Liverpool University Press, 2013); Andrew Bielenberg, ed., The Irish Diaspora (London and New York: Routledge, 2013); Piaras Mac Éinrí and Tina O'Toole, "Editors' Introduction: New Approaches to Irish Migration," Éire-Ireland 47, no. 1\&2 (Spring/Summer, 2012): 5-18.

${ }^{5}$ Mark G. McGowan, The Waning of the Green: Catholics, the Irish, and Identity in Toronto, 1887-1922 (Montreal and Kingston: McGill-Queen's University Press, 1999); Bruce S. Elliott, Irish Migrants in the Canadas: A New Approach (Montreal and Kingston: McGill-Queen's University Press, 2004); Donald Harman Akenson, The Irish in Ontario: A Study in Rural History (Montreal and Kingston: McGill-Queen's University Press, 1999).
} 
Irish Protestants in general. She expands on this to argue that local colonial authorities created records which reflected their ideas about whiteness and masculinity, and concludes that "the Irish as colonial subjects were not 'white enough' or 'male enough' to be understood as the forgers of Canadian colonial history in the west." ${ }^{\prime 6}$

Allan Rowe is interested in the migration of the Irish in the Prairie Provinces from the 1870 s to the early 1930 s. He suggests that the Irish lacked the same kind of visibility that non-Anglophone ethnic groups have had, which may explain why groups such as Ukrainians, Mennonites, and Icelanders have tended to dominate studies of migration in the prairies. Rowe argues, nonetheless, that Irish migration to the west resulted in a distinct regional Irish identity that was negotiated within the context of the global diaspora, the British Empire, and the Canadian nation. Irish immigrants moved from the eastern provinces (particularly Ontario) to the west and settled in both rural and urban areas. Rowe notes that the Irish in Winnipeg established the most discernible presence, establishing both sectarian and non-sectarian ethnic associations such as St Patrick's Society of Manitoba (est. 1874), the Irish Protestant Benevolent Association (est. 1900), and the St. Patrick's Benevolent Society (est. 1883). Some chose to identify along sectarian lines and events and movements like the Boer War and Home Rule could have a significant effect on the activities of these associations. ${ }^{7}$ However, Rowe argues that the primary identity emphasized by these groups was regional. He states, "The Prairie Irish

\footnotetext{
${ }^{6}$ Angèle Smith, "Fitting into a New Place: Irish Immigrant Experiences in Shaping a Canadian Landscape," International Journal of Historical Archaeology 8, no. 3 (September, 2004): 224-226. ${ }^{7}$ The Orange Order also played an important role in Manitoba, with the establishment of the province's first Orange lodge in 1870. The arrival of thousands of Protestant Irish from Ontario led to the Orange Order's expansion. This organization was involved in local politics, emerging as a strong opponent to the Catholic Francophone position on the Manitoba Schools Question in the 1890s. Allan Rowe, "Prairie Shamrock: Irish Settlement and Identity in Western Canada, 1870-1930s" (PhD diss., University of Alberta, 2008), 102-103.
} 
reconciled and fused their Irishness with broader identities, including imperialism, Canadianism and most critically regional citizenship."8

In terms of Irish oral history projects in Canada, the list is even shorter. Studies in this category include Sheelagh Conway's The Faraway Hills are Green: Voices of Irish Women in Canada (1992), Johanne Devlin Trew's study of Northern Irish emigration entitled Leaving the North: Migration and Memory, Northern Ireland 1921-2011 (2014), and rhetoric scholar Jennifer Clary-Lemon's 2010 article, “ 'We're not ethnic, we're Irish!': Oral histories and the discursive construction of immigrant identity." Conway traveled across Canada in 1989, interviewing and photographing Irish women. She provides historical context in the first part of her book before presenting transcripts of the interviews but provides little analysis of the interviews themselves. ${ }^{9}$ Trew, on the other hand, offers both historical background and considerable analysis in her book, in which she discusses interviews with Irish migrants who had settled in parts of the British Empire, including Canada, and return migrants. In her section about Northern Irish immigrants living in Canada, Trew is particularly interested in her interviewees' experiences with finding work, as well as feelings of homesickness. ${ }^{10}$ Clary-Lemon conducted interviews with Irish Canadians in Winnipeg who arrived during this period, specifically 15 members of the Irish Association of Manitoba. Her focus is on how identities, both immigrant and national, are constructed through language. She analyses

\footnotetext{
${ }^{8}$ Ibid., 1-5, 110, 129, 248-249, 251.

${ }^{9}$ Sheelagh Conway, The Faraway Hills are Green: Voices of Irish Women in Canada (Toronto: Women's Press, 1992).

${ }^{10}$ Trew, Leaving the North, 158-190.
} 
the discursive qualities of the interviews, and argues for oral history as a methodology in the study of rhetoric. ${ }^{11}$

It is also worth noting Marilyn Barber and Murray Watson's oral history, Invisible Immigrants: The English in Canada since 1945 (2015). This study concentrates on the migration experiences of English newcomers during the post-war period: their decision to migrate, the difficulties of separating from their families, the challenges of adjusting to their lives in Canada, and the ways in which they connected to their heritage and the homeland. While English immigrants' experiences are significantly different from those of Irish immigrants, there are points of commonality. For example, neither of these groups are visible minorities, but both are easily identifiable through their accents. Barber and Watson also recognize the significance of weather and landscape in English migrants' process of adaptation and feelings of belonging. ${ }^{12}$ In my study, I examine how these narratives about environment work as communicative tools and the ways in which biography, landscape, and climate are deeply intertwined.

My project puts my interviewees' stories into their historical context, reflects on their particular circumstances as Irish migrants in the prairies, and considers the role of individual and collective memory in these migrant narratives. In particular, I examine the role of performance as well as landscape and weather in interpreting these memories in their new context. I examine how identity, culture, and history are negotiated and how

\footnotetext{
${ }^{11}$ Jennifer Clary-Lemon, “'We're not ethnic, we're Irish!': Oral Histories and the Discursive Construction of Immigrant Identity," Discourse Society 21, no. 1 (2010): 5-7, 20-21. As far as I can tell from her article, there was no overlap in our interviewees.

${ }^{12}$ Marilyn Barber and Murray Watson, Invisible Immigrants: The English in Canada since 1945 (Winnipeg, MB: University of Manitoba Press, 2015), 1-5. Pauline Greenhill's research on English Canadians also covers material that overlaps with this study. In particular, she examines the role of folk performances, such as Morris dancing, within English communities in Ontario. Pauline Greenhill, Ethnicity in the Mainstream: Three Studies of English Culture in Ontario (Montreal and Kingston: McGill-Queen's University Press, 1994), 64-129.
} 
descriptions of significant actions which constitute a repertoire give insight into migration experiences and relationships with the past.

All of my interviewees migrated to Canada in the post-war period - a time in Ireland that was characterized by ebbs and flows in migration, both out of and onto the island. The difficult economic times of the 1950s and late "70s and ' 80 s saw rises in net emigration while the " 60 s and the Celtic Tiger of the ' 90 s saw a switch to net immigration into the country. Political conflict in Northern Ireland reached its peak between 1971 and 1976, galvanized in part by civil rights movements occurring in America and elsewhere in the world. This conflict, known as the Troubles, stimulated both internal migration and emigration. ${ }^{13}$ The interviewees involved in this project migrated to Canada in three distinct waves: the 1950s, the 1970s and 1980s, and a recent migration wave which started in $2011 .{ }^{14}$

Winnipeg, in contrast to Ireland, experienced a steady influx of migration during this time. In the immediate post-war period there was large migration from Europe to major Canadian cities, including Manitoba's capital. In addition, people in rural areas of all the provinces were moving to urban centres, which contributed to a steady increase in Winnipeg's population. In the 1970s and the decades that followed, the largest migrant populations coming to Winnipeg were from parts of Latin America, Asia, Africa, the Caribbean, and the Mediterranean, as well as significant numbers of First Nations peoples moving from reserves to the City. ${ }^{15}$ At present, a substantial proportion of Winnipeg

\footnotetext{
${ }^{13}$ Fitzgerald and Lambkin, Migration in Irish History, 224, 236, 248.

${ }^{14}$ Mary Gilmartin, "The changing landscape of Irish migration, 2000-2012," (working paper, National Institute for Regional and Spatial Analysis Working Paper Series, National University of Ireland, Maynooth, October, 2012), 10.

${ }^{15}$ Royden Loewen and Gerald Friesen, Immigrants in Prairie Cities: Ethnic Diversity in Twentieth-Century Canada (Toronto: University of Toronto Press, 2009), 77, 139.
} 
residents claim Irish heritage. According to the 2006 census, Winnipeg has a population of approximately 678,000 and roughly 75,000 or $11 \%$ identify as being of Irish heritage. Of these, 4,225 identified themselves as immigrants and ten of these agreed to participate in this project. ${ }^{16}$

I began recruiting interviewees by locating and contacting a local ethnic association called the Irish Association of Manitoba. I posted an advertisement for the project in their newsletter and Tom Naughten was one of three interviewees to respond. A native Dubliner, Tom was born in May 1954 into what he described as a strong, matriarchal family. He left Ireland first when he was in high school to work in England for one summer and then in Vancouver for another summer during his college years. After completing his first degree at Trinity College in Dublin, he decided to pursue graduate studies in geography at Simon Fraser University. Afterwards he worked in the Yukon for many years before settling in Winnipeg in 1990 where he and his wife Heather (whom he met through the Irish Club) raised their two sons. Tom also introduced me to his mother-in-law, Eileen Baxter, who was born in Belfast in June 1935. Eileen and her

\footnotetext{
${ }^{16}$ Statistics Canada, 2006 Census of Canada topic based tabulation Ethnic Origin (101), Age Groups (8), Sex (3) and Selected Demographic, Cultural, Labour Force, Educational and Income Characteristics (309), for the Total Population of Canada, Provinces, Territories, Census Metropolitan Areas and Census Agglomerations, 2006 Census - 20\% Sample Data, (Catalogue no. 97-564-XCB2006007), retrieved 3 August 2015 from Statistics Canada, https://www12.statcan.gc.ca/census-recensement/2006/dp$\mathrm{pd} / \mathrm{tbt} / \mathrm{Rp}-$ eng.cfm? $\mathrm{LANG}=\mathrm{E} \& \mathrm{APATH}=3 \& \mathrm{DETAIL}=1 \& \mathrm{DIM}=0 \& \mathrm{FL}=\mathrm{A} \& \mathrm{FREE}=0 \& \mathrm{GC}=0 \& \mathrm{GID}=0 \& \mathrm{GK}=$ 0 \&GRP $=0 \& \mathrm{PID}=97614 \& \mathrm{PRID}=0 \& \mathrm{PTYPE}=88971,97154 \& \mathrm{~S}=0 \& \mathrm{SHOWALL}=0 \& \mathrm{SUB}=801 \& \mathrm{Te}$ mporal $=2006 \& T H E M E=80 \& V I D=0 \& V N A M E E=\& V N A M E F$. The total population of those with Irish ethnic origins in Winnipeg includes those 15 years and over. It is worth noting that 2525 identified as having emigrating from the United Kingdom. It is difficult to determine based on the information available whether these figures refer to those who emigrated from Northern Ireland who have identified themselves as of Irish ethnic origin or those whose ancestors may have originated from the Republic but migrated to the United Kingdom. Johanne Devlin Trew has done extensive research concerning Northern Irish migration and has found that between 1930 and 1964, over 50\% of Irish immigrants to Canada originated from Northern Ireland. She also points out that by the 2006 census, Irish migration to Canada from both the Republic and Northern Ireland had significantly reduced. Trew, Leaving the North, 165-166.
} 
husband Ralph, an Anglican minister, left Northern Ireland in 1975 with their two daughters and came to Winnipeg. She worked as a librarian in the River East Transcona School Division until the birth of her oldest grandchild.

Eileen was one of two interviewees from Northern Ireland as well as the only one who was raised Protestant. She and Greg McVicker, also born in Belfast, provided much needed perspectives from Northern Ireland which helped round out this study. Greg, born July 1970, was raised Catholic and left Belfast with his family as a teenager in 1985 . He has worked as a social worker for many years and has also written several books and poems on his memories of Ireland and his experience of migration. ${ }^{17}$ I connected with Greg after stumbling upon his self-published book, Through the Eyes of a Belfast Child: Life. Personal Reflections. Poems (2014), in a local bookstore. He included an email address in the back, inviting readers to share their stories with him and was kind enough to agree to participate in this project when I contacted him.

I also spoke with Patrick (Pat) Gannon (born 1947) who, now retired, worked for many years in the Finance Department of the provincial government and who is a close friend of my father. When he heard I was interviewing Irish Canadians in Winnipeg, he graciously agreed to participate. He also put me in touch with his sister Catriona Younger (born 1951) who is also living in Winnipeg and currently teaches Technical Communication at Red River College. The siblings were raised in Cootehill, County Cavan with their two brothers. They left Ireland as children when their family migrated to Winnipeg in 1957 and both Pat and Catriona have remained in Manitoba to raise their

\footnotetext{
${ }^{17}$ Greg McVicker, Through the Eyes of a Belfast Child: Life. Personal Reflections. Poems (Victoria, BC: FriesenPress, 2014); Greg McVicker, Silly Billy and the Postage Stamp (Winnipeg, MB: Greg McVicker, 2015), Kindle Edition; Greg McVicker, An Irish Heart: Journey of a Belfast Child (Winnipeg, MB: Greg McVicker, 2014), Kindle Edition. I will return to Through the Eyes of a Belfast Child in my first chapter.
} 
families. They were part of the earliest wave of Irish migration among the interviewees, while Shirley Foamete is the latest migrant to Winnipeg within this assembly. Born July 1971 and raised in Cork, she first visited Winnipeg in 1999 for her sister's wedding and eventually moved to Manitoba in 2012 with her two sons. I connected with her through my post in the Irish Club's newsletter and when we spoke she joked, "So I spent forty years in Ireland. I'll spend the next forty in Canada. And then the last ten I'll move back." 18

Maureen Taggart, who also responded to the ad in the Club newsletter, came to Winnipeg in 1971 when her husband Hugh got a job teaching in the city. She was born in 1946 and was raised by her grandparents in the countryside of County Tipperary near Cappawhite while her parents lived and worked in England. She worked in the University of Winnipeg library and has been heavily involved in the Winnipeg theatre community. She introduced me to actor and author Brian Richardson, whom she met during her first year in Winnipeg in a theatre production of Juno and the Paycock and who has been a close friend ever since. Born in 1945 and raised in Dun Laoghaire, County Dublin, Brian first moved to Potsdam, New York, to study biology but decided to pursue acting. He moved to Canada and lived in Montreal and Halifax for a few years before heading out west with a friend from Manitoba in 1970. As they were passing through Winnipeg their car broke down and he ended up settling in the city. He has made his living through his art and has worked as an actor, storyteller, musician, director, playwright, and poet.

Brian put me in touch with the couple Joe and Mary Campbell, whom I interviewed together. Joe was born in March 1934 in Dublin and joined the Dominican

\footnotetext{
${ }^{18}$ Shirley Foamete, interview by Kathryn Boschmann, Winnipeg, Manitoba, 26 June 2014, Part 1.
} 
Order after high school. He studied in Rome and taught in India before deciding to leave the Order and pursue his doctoral degree in Clinical Psychology at the University of Manitoba in 1972. While living in Winnipeg he met and married Mary (nee Kelly) in 1975. Born in December 1944, Mary was raised in Nenagh, County Tipperary. She studied nursing in England and worked in Dublin as a midwife. In 1973 she visited her sister who was living in Winnipeg and decided to stay. The couple returned to Ireland in 1978 but came back to Winnipeg seven years later where they raised their three children.

In addition to these interviews, I also traveled to Ireland in August 2014. This trip was funded by the Carleton Centre for the History of Migration ${ }^{19}$ and enabled me to gather research material at the Centre for Migration Studies in Omagh, the National Wax Museum Plus, and the Comhaltas headquarters in Dublin. I also interviewed scholars in the field of Irish migration history whose perspectives I will cite occasionally in what follows. In addition, I was able to go to some of the places interviewees had mentioned in our conversations, such as Dublin, Doolin, and the Cliffs of Moher. This was of considerable value as it helped me to better understand their narratives.

My oral history interviews constitute the research core of this study. Oral history is a way of creating historical sources as well as a theoretical and methodological discipline, often used to bring stories not typically found in traditional sources into historical discourse.$^{20}$ There are many ways to approach oral history interviews, and methods of interpretation are often modified to reflect both the project and the individuals

\footnotetext{
${ }^{19}$ I would like to thank the Shannon Fund of the Carleton Centre for the History of Migration for financing this research trip.

${ }^{20}$ Kirstina R. Llewellyn, Alexander Freund, and Nolan Reilly, "Introduction," in The Canadian Oral History Reader, eds. Kirstina R. Llewellyn, Alexander Freund, and Nolan Reilly (Montreal and Kingston: McGill-Queen's University Press, 2015), 5.
} 
involved. ${ }^{21}$ For this project, interviews could last anywhere between an hour and a half to nearly three hours and were typically conducted in the interviewees' homes, save for Greg and Brian whom I interviewed in a restaurant and an Oral History Centre interview room at the University of Winnipeg, respectively. I prepared open ended questions before each interview based on the concerns of my project while giving ample space for interviewees to take the discussion in directions they wanted. ${ }^{22}$ Follow-up interviews were organized if we had not touched on all of the questions I prepared in the first sitting and providing they had time for a second meeting.

Oral historians often struggle with the power dynamics inherent in the process of collecting and then analyzing interviews. When we start a project we select the interviewees, decide upon the research parameters, and then we select particular stories from the conversations to speak to a particular subject, effectively controlling how the interviewees' stories are told in the context of our research. At the same time, participants in the project have significant control over what and how they decide to share with the

\footnotetext{
${ }^{21}$ Much has been written concerning oral history methodology and ethics. For more on this subject, see: Julie Cruikshank, "Claiming Legitimacy: Prophecy Narratives from Northern Aboriginal Women," American Indian Quarterly 18, no. 2 (Spring, 1994); Alexander Freund, "A Canadian Family Talks about Oma's Life in Nazi Germany: Three-Generational Interviews and Communicative Memory," in The Canadian Oral History Reader, eds. Kirstina R. Llewellyn, Alexander Freund, and Nolan Reilly (Montreal and Kingston: McGill-Queen's University Press, 2015), 159-179; Henry Greenspan, On Listening to Holocaust Survivors: Beyond Testimony (St. Paul, MN: Paragon House, 2010); Kristina R. Llewellyn, "Productive Tensions: Feminist Readings of Women Teachers' Oral Histories," in The Canadian Oral History Reader, eds. Kirstina R. Llewellyn, Alexander Freund, and Nolan Reiy (Montreal and Kingston: McGill-Queen's University Press, 2015), 141-158; Joan Sangster, "Telling Our Stories: Feminist Debates and the Use of Oral History," in The Oral History Reader, eds. Robert Perks and Alistair Thomson (London and New York: Routledge, 2005), 87-100; Alexander von Plato and Edith Burley, "Contemporary Witnesses and the Historical Profession: Remembrance, Communicative Transmission, and Collective Memory in Qualitative History," Oral History Forum d'histoire orale 29 (2009): 1-27; Valerie Yow, "Ethics and Interpersonal Relationships in Oral History Research," The Oral History Review 22, no. 1 (Summer, 1995): 51-66.

${ }^{22}$ For examples of the kinds of open ended questions I asked in the interviews, see Appendix III.
} 
interviewer. The interview is co-created by both historian and participant. ${ }^{23}$ Alessandro Portelli reminds us that when we conduct oral history interviews, we should place ourselves in a position of mutual learning, while still applying our skills as historians. We are not studying sources, as we do in archives, but listening to living people tell their stories in the way they understand them. ${ }^{24} \mathrm{He}$ argues, "Oral history does not begin with one abstract person observing another, reified one, but with two persons meeting on a ground of equality to bring together their different types of knowledge and achieve a new synthesis from which both will be changed." 25

I approached my interviews as a conversation, but one in which I was the student learning from and engaging with the experts. Most of my interviewees were well acquainted with Irish history, were involved in the arts, and demonstrated considerable self-reflexivity. A conversation involves participation from both interlocutors, and while I limited my interventions, I did share my thoughts on certain subjects as well as my own stories. Approaching the interview in this way recognizes that it is a collaborative process between interviewee and interviewer. Portelli explains the importance of establishing mutuality in order to respect the equality of our interviewees (breaking down the barrier of intellectual otherness) while also recognizing our differences. ${ }^{26}$ In many ways, it was helpful that I was an outsider to this community (as a German-Mennonite), and had had relatively little exposure to Irish history prior to this project. It contributed to interviewees' comfort in sharing their thoughts about their history without worrying that I

\footnotetext{
${ }^{23}$ Alessandro Portelli, "The Peculiarities of Oral History," History Workshop Journal 12, no. 1 (1981): 100-105; Alessandro Portelli, "A Dialogical Relationship: An Approach to Oral History," Expressions Annual 14 (2005), accessed 2 July 2015, http://www.swaraj.org/shikshantar/expressions_portelli.pdf.

${ }^{24}$ Portelli, The Death of Luigi Trastulli and Other Stories, $\mathrm{x}$-xi.

${ }^{25}$ Ibid., xii.

${ }^{26}$ Ibid., 31-32, 37-38, 42-44.
} 
might be invested in a different version of the story or call them out on factual

inaccuracies.

Oral historian Michael Frisch introduced the concept of shared authority which draws on ideas of grassroots activism and argues for a partnership between scholars, their interviewees, and the public. This concept has been used to extend the collaboration into the final research product. While this approach has generated compelling discussion, it requires a great deal of time and an extended commitment from both parties, and is not ideal for every project. For example, both interviewer and interviewees might be faced with time constraints that do not allow for the in-depth collaborative research fully sharing authority entails. Even so, as oral historian Steven High points out, the concept pushes us to critically consider our authority and subjectivities as researchers. ${ }^{27}$

\footnotetext{
${ }^{27}$ Steven High, "Sharing Authority: An Introduction," Journal of Canadian Studies/Revue d'études canadiennes 43, no. 1 (Winter, 2009): 12-15; Lynn Abrams, Oral History Theory (London and New York: Routledge, 2010), 166-167. Linda Shopes points out how the concept of "shared authority" between interviewer and interviewee has been used so often and in so many contexts that it has now been reframed into "sharing authority", which refers to a collaborative process in which the historian negotiates the outcome among participants. She quotes Frisch who clarified his original meaning: "The construction 'Sharing Authority' suggests this is something we do - that in some important sense 'we' have authority, and that we need or ought to share it. 'A Shared Authority,' in contrast, suggests something that 'is' - that in the nature of oral and public history we are not the sole interpreters. Rather, the interpretive and meaning making process is in fact shared by definition - it is inherent in the dialogical nature of an interview." (Author's emphasis.) Linda Shopes, “'Insights and Oversights': Reflections on the Documentary Tradition and the Theoretical Turn in Oral History," The Oral History Review 41, no. 2 (2014): 265. "Shared authority" is, in many ways, more difficult to achieve, as it requires the interviewer and interviewee to reach the level of comfort where they can discuss different viewpoints, confront one another, and agree to disagree. Ibid., 264-266. Also see: Katharine T. Corbett and Howard S. Miller, "A Shared Inquiry into Shared Inquiry," The Public Historian 28, no. 1 (Winter, 2006): 15-38; Alexander Freund, "Confessing Animals': Toward a Longue Durée of the Oral History Interview," The Oral History Review 41, no. 1 (2014): 1-26; Daniel Kerr, “'We Know What the Problem Is': Using Oral History to Develop a Collaborative Analysis of Homelessness from the Bottom Up," The Oral History Review 30, no. 1 (2003): 27-45; Joy Parr "“Don't Speak for Me': Practicing Oral Histories amid the Legacies of Conflict" in The Canadian Oral History Reader, eds. Kirstina R. Llewellyn, Alexander Freund, and Nolan Reiy (Montreal and Kingston: McGill-Queen's University Press, 2015), 335-346; Linda Shopes, "Commentary: Sharing Authority," The Oral History Review 30, no. 1 (2003): 103-110; Pamela Suigman, "'Life is Sweet': Vulnerability and Composure in the Wartime Narratives of Japanese Canadians," Journal of Canadian Studies/Revue d'études canadiennes 43, no. 1 (Winter, 2009): 186-218; Alistair Thomson, "Sharing Authority: Oral History and the Collaborative Process," The Oral History Review 30, no. 1 (2003): 23-26;
} 
My approach to sharing authority in the process of conducting and analyzing interviews has not been to speak for my interviewees, but to speak to the particular stories they shared with me at a particular point in time. I have placed these stories in a wider historical context, analyzed the interview recordings on an individual level and as a whole, and located meaning in the similarities and differences. While there were time constraints and issues of distance, I attempted to include my interviewees in the writing process by ensuring they have had the opportunity to make comments and raise questions or concerns before my work opens to the public. To do this, I have sent out chapter drafts for interviewees to review. This attempt at sharing authority is limited, in that it does not provide ideal conditions for interviewees to enter into a conversation with me about my arguments. However, it opened the door for this kind of interaction. ${ }^{28}$

Oral histories have been recorded and collected in large quantities but archives are faced with the challenge of effectively storing and maintaining them, as well as making these sources accessible to the public. Digital history offers new opportunities to make interviewee voices accessible to the readers of oral histories, providing new options (and, it should be noted, challenges) for archives and novel ways to present oral history findings to the public. An accompanying website (http://www.beingirishontheprairies.ca/) fulfills several purposes for this research project. First, it acts as a way to offer something back to the community which has been so welcoming and generous. The website presents

\footnotetext{
Stacey Zembrzycki, "Sharing Authority with Baba," Journal of Canadian Studies/Revue d'études canadiennes 43, no. 1 (Winter, 2009): 219-238.

${ }^{28}$ Not all interviewees responded when I sent out the rough drafts but those who did were positive in their comments and did not request any major changes. While some were more detailed than others in explaining their thoughts on the project, communicating via email did not allow for an in-depth conversation about the draft. In addition, I was anxious to respect my interviewees' busy schedules and the fact that some may not have had time to invest in reading the chapters I sent them. I also intend to give interviewees the chance to comment on the website and may revise it in the future should they raise concerns.
} 
aspects of my research in an easily accessible format and also allows visitors to hear the voices of my interviewees. Second, orality and aurality are central in oral history theory and methodology. Listening to the way people tell their stories (tone of voice, pace, pauses, hesitations, moments of overwhelming emotion, etc.) is crucial to understanding the interview as a source and many of these nuances are lost in the process of transcription. ${ }^{29}$ In addition, the website brings attention, to a greater degree than the transcribed passages included in the written portion of the thesis, to how the interviews were a conversation and how my own voice featured in this process.

While the material presented on the website is related to the written chapters of my thesis, the website develops further the topic of emotional memory. Visitors can listen to how interviewees describe their relationship with Ireland and Canada, which is deeply connected to ideas about the past, identification with particular landscapes, and family ties. I unpack these themes in short write-ups which accompany the clips and have included live links in the footnotes of this thesis to clips that relate to the subject matter of the written chapters. This allows readers to easily access the website and listen to my interviewees' voices. The clips then do the double duty of addressing the topic specific to the website while also speaking to the ideas presented in the written portion of the thesis.

${ }^{29}$ Portelli, Death of Luigi Trastulli and Other Stories, 46-48; Abrams, Oral History Theory, 19-20; Douglas A. Boyd and Mary A. Larson, "Introduction," in Oral History and Digital Humanities: Voice, Access, and Engagement, Douglas A. Boyd and Mary A. Larson, eds. (New York: Palgrave Macmillam, 2014), 7; Douglas A. Boyd, "Oral History Archives, Orality, and Usability," in Oral History and Digital Humanities: Voice, Access, and Engagement, Douglas A. Boyd and Mary A. Larson, eds. (New York: Palgrave Macmillam, 2014), 77-79; High, "Sharing Authority," 24-29. Some examples of compelling digital presentations of oral history projects include: Stacey Zembrzycki, "According to Baba: A Collaborative Oral History of Sudbury's Ukrainian Community," last modified 26 October 2014, http://www.sudburyukrainians.ca/; Paul Shoebridge and Michael Simons, "Welcome to Pine Point," accessed 05 August 2015, http://pinepoint.nfb.ca/\#/pinepoint; Joy Parr, Jon Van der Veen, and Jessica van Horssen, "Megaprojects New Media," accessed 05 August 2015, http://megaprojects.uwo.ca/. Parr, van Horssen, and van der Veen also wrote an article on the reasoning and process behind this website: Joy Parr, Jon Van der Veen, and Jessica van Horssen, "The Practice of History Shared across Differences: Needs, Technologies, and Ways of Knowing in the Megaprojects New Media Project," Journal of Canadian Studies/Revue d'études canadiennes 43, no. 1 (Winter 2009): 35-56. 
In the first chapter of the written portion of this project, I do not analyze song or dance as a folklorist might; rather I examine the differences in how my interviewees spoke about traditional Irish performances and the role these activities were described as playing in their lives both in Ireland and in Winnipeg. The context of their migration experience is central to this relationship as traditional performances had different connotations at particular times and locations in Ireland. I argue that these performances have a political provenance. This affects not only how individuals relate to them, but has led also to debates within the community concerning which performances are appropriate in spaces explicitly intended to distance the community from Ireland's historical divisions. For example, the Irish Association of Manitoba, typically referred to as the Irish Club, was formed in 1972 (the same year British paratroopers opened fire on civil rights protestors in Derry, killing thirteen unarmed civilians in an event that came to be known as 'Bloody Sunday') with the public mandate to be not-for-profit, non-political, and non-sectarian. ${ }^{30}$ The intention was to bring Irish people together but without replicating Ireland's fraught politics - or, as Aidan O'Brien (a founder of the Irish Association of Manitoba and its first president) stated in a letter to the Winnipeg Free Press, the goal of the Association was "to prove that Irish people of all economic and religious backgrounds have the ability to live together in peace and harmony." ${ }^{31} \mathrm{~A}$ consequence of this mandate was that the Club had to focus on activities that did not support either side of the debate around Irish unity and were inclusive for both Protestant and Catholic Irish living in Winnipeg. However, the choice to depoliticize the Club and its engagement with the Irish past is, in itself, a political decision. My interviews revealed

\footnotetext{
30 "Irish Association Formed," Winnipeg Free Press, 28 November 1972; The Irish Association of Manitoba, "About Us," accessed 5 August 2015, http://www.irishassociation.ca/index.php/aboutus.

${ }^{31}$ Aidan J. O'Brien, letter to the editor, "Irish Association," Winnipeg Free Press, 24 January 1973.
} 
a certain amount of tension over which performances should be included in the community's repertoire now that they inhabit a new place.

The second chapter extends the concept of repertoire to interactions with the physical environment. Part of migration is adapting to a new place and the interviewees involved in this project had to adjust to a significantly different landscape and climate. Their descriptions of the respective environments of Ireland and Manitoba were often connected to emotional stories about adjustment to their new home. I argue that when we learn how to interact with a new landscape and its elements, our responses take on meanings and become part of an environmental repertoire. As we learn how to be in new environments, our expanding repertoire overlaps with those of others who inhabit the land and share those experiences, creating a particular kind of common ground. Examining these stories about interaction with land and weather through the lens of repertoire draws attention to an important part of the migration experience both in terms of the process of developing a sense of belonging to a new place and of the narrative power of the environment.

Taylor's concept of repertoire helps us identify alternative ways that people engage with their past. As Dening states, history is "an everyday thing, saturating every moment of cultural existence. Making sense of what has happened is how we live. We do it in all sorts of ways. We sing it, dance it, carve it, paint it, tell it, write it. We find different ways to make sense of what has happened according to the different occasions of our telling and the different audiences to which we tell it." ${ }^{\prime 2}$ Stories about our pasts are a part of everyday life and are constantly shaping our relationship with our personal and

\footnotetext{
${ }^{32}$ Dening, Performances, xiv.
} 
communal histories, as well as our ideas of who we are and where we belong. I analyze a particular set of stories which are part of this larger process of narrating the past and relating current identities to a wider history. 


\section{Chapter One \\ "Some cultural thing to hang my hat on": Performance and memory among Irish Canadians in Winnipeg}

Sociologist Erving Goffman wrote that "All the world is not, of course, a stage, but the crucial ways in which it isn't are not easy to specify." ${ }^{\prime \prime}$ Performance plays a crucial role in our daily lives. The kinds of activities we engage in on a regular basis play a significant role in how we understand ourselves, present our identity to others, and find communities. The performance activities that are traditional to a culture signal to others something about who we are and with which communities we identify. Over time, they become infused with meanings and emotional associations for those who repeatedly participate as either performers or audiences. My interviews with first generation Irish Canadians in Winnipeg demonstrate the deep connection between historical narratives and traditional performances. The political associations these activities have acquired often make them the centre of collective memory divisions within the community and provide insight into how engagement with the past is negotiated.

To analyze these tensions, I am drawing on the work of scholars who have considered the importance of performance as a way of defining identity and expressing relationships with the past. Diana Taylor has argued that performances constitute a repertoire, a kind of embodied archive, or a way of remembering and transmitting knowledge about the past to ourselves and others. These repeated, significant acts play an important role in producing and exhibiting the identity of the performers, establishing a sense of belonging to a particular group of people and a particular history. The significance of these actions is understandable to an audience that shares that repertoire

\footnotetext{
${ }^{1}$ Erving Goffman, The Presentation of Self in Everyday Life (New York: Anchor Books, 1959), 72.
} 
and is aware of the meaning that those performances carry within different contexts. Taylor uses the term scenario to describe the contexts and frameworks of these activities. Scenarios set the stage for particular performances in which actors produce and share understandings of the historical significance of the activities in which they are engaging. ${ }^{2}$

For example, consider an Irish traditional music session. The scenario is set when people gather together in certain kinds of locations (a local pub or a friend's living room, for example) with the intention of playing music together. These people draw from a pool of songs which are familiar to most, if not all, of the musicians and which make up part of the repertoire of the session. For some participants this runs deeper to a knowledge of the genealogy and past significance of the songs as well as a communal understanding of the boundaries of appropriate behaviour within the session. Meaning is produced and transmitted to other players and the audience not only by the songs being played and the style the musicians choose to use (which could indicate origins from a particular county in Ireland or knowledge of regional styles) but also through the social activity of playing together. This contributes to a sense of belonging to a group of people with a shared appreciation of Irish music and culture and often a feeling of being connected with a wider international Irish community. In this way, the musical event conveys knowledge about Irish culture and memory to the audience and the performers who are participating in the cultural repertoire. These performances are replicated and "reconstitute themselves, transmitting communal memories, histories, and values from one group/generation to the

\footnotetext{
${ }^{2}$ Diana Taylor, The Archive and the Repertoire: Performing Cultural Memory in the Americas (Durham, NC: Duke University Press, 2003), 2-3, 16-21, 28-33.
} 
next." ${ }^{\prime 3}$ They are a means by which people share and, in a way, record knowledge about social codes, historical memory, and identity.

This repertoire of performances and its connection to Irish historical memory was compellingly described by Tom in our second interview. He explained how the winners of the Comhaltas All Ireland competition ${ }^{4}$ come to Winnipeg every few years to put on a concert and lead a day of workshops. Sometimes these workshops will be about new techniques but other times they focus on the history of the tunes themselves which, as Tom points out, is also very important to Irish musicians:

T: And sometimes they'll come into classes and they'll sit down and they won't play the whole time. Like they'll be talking about flute music, but they'll talk about those regional styles; they'll talk about the people; they'll talk about the tunes associated with individual people; they'll talk about family histories.

$\mathrm{K}$ : Really?

$\mathrm{T}$ : Which, to them, can be just as important as the tunes themselves, you know. It's like archaeology. Object. Object doesn't mean a damn thing. It's the provenance of the object to tell you where it was found in the layers and howwhat other pieces it's associated with. That provenance, that data is what makes this chip of a cup important or not. Or whatever. But it's the provenance that's the key. It's the provenance of a tune; it's the provenance of-of-of the-the-the history of that tune. Where does it come from, who does it come from, who played it, how did they play it, where did they play it, when did they play it.

$\mathrm{K}$ : Yeah.

T: You know, um. All traditions, whether you're talking about deepest, darkest Africa or somewhere in the middle of China, the provenance for the music and the culture is- it's as important as anything else. ${ }^{5}$

Without that history, without the tradition, the music would not have the same significance. The performance of these pieces takes on significance and helps shape individual and communal identity in the present because of the associations they have

\footnotetext{
${ }^{3}$ Ibid., 21.

${ }^{4}$ A national music competition in Ireland. This event will be discussed at greater length later in this chapter.

${ }^{5}$ Tom Naughten, interview by Kathryn Boschmann, Winnipeg, Manitoba, 10 June 2014, Part 2.
} 
acquired with a history and a people. Their connection to the past enhances their perceived authenticity and authority within the community.

Tom's choice of words is a helpful way to consider how music and other performances take on meaning within a cultural context. Provenance describes the history of ownership and location of an object which contributes to assurance of the authenticity of a piece and understandings of how it has been used over time. ${ }^{6}$ Knowledge about who wrote a song or with whom it is associated with, where and when it has been and is typically performed, and how it has changed over the years, gives that song legitimacy within a repertoire (for example, that this is a song written in Ireland or by an Irish songwriter and belongs within the repertoire of Irish traditional tunes). This awareness also provides understanding of the appropriate time and audience for a piece. ${ }^{7}$ As these songs are repeatedly played in different places, by and for different people, and for particular occasions, they pass on stories about the past, take on new meanings, and do important memory work.

\footnotetext{
${ }^{6}$ The definition of provenance differs slightly between fields. In archaeology it refers specifically to the context in which a historical object was found. In art history and archival practice it is used to describe the record of the history of an object (for example, a piece of art, a written document, or a material artifact) from the point of creation to the present, particularly in terms of ownership and whereabouts, which contributes to its legitimacy and historical authority. Timothy Darvill, The Concise Oxford Dictionary of Archaeology, $2^{\text {nd }}$ ed., s.v. "provenance" (Oxford: Oxford University Press, 2009); Ian Chilvers, The Oxford Dictionary of Art, $3^{\text {rd }}$ ed., s.v. "provenance" (Oxford: Oxford University Press, 2004). Tom refers specifically to the archaeological definition of provenance. However, the art history/archival use of this term also fits with his description and I will primarily be using provenance according to this definition. ${ }^{7}$ John O'Flynn examines the ways some songs are considered more "Irish" than others by both music corporations and consumers of Irish music. He argues that within Irish culture there are strong ideas of a collective consciousness based on almost spiritual connections to certain kinds of music. These associations between "Irishness" and music not only influence how different genres of music produced in Ireland are perceived but also affect ideas of musical authenticity. John O'Flynn, The Irishness of Irish Music (Surrey: Ashgate Publishing Ltd., 2009), 2-5, 8-9, 94, 100-102, 194-195, 199-201. For more on the contested nature of Irish traditional music see, Helen O'Shea, The Making of Irish Traditional Music (Cork: Cork University Press, 2008); Gerry Smyth, Music in Irish Cultural History (Sallins, KE: Irish Academic Press, 2009); Martin Dowling, Traditional Music and Irish Society: Historical Perspectives (Surrey: Ashgate Publishing Ltd., 2014).
} 
In this chapter, I argue that my interviewees' narratives about traditional performances reveal the deep connections these cultural repertoires have with Irish history, as well as how that history resonates within a new setting. While I will focus primarily on how these individuals talk (or, in some cases, write) about traditional music, I will also examine discussions concerning other kinds of cultural performances, such as festivals, parades, and club activities. Most interviewees see these performance activities as ways to connect to a particular past, people, and identity (which is related to concepts of provenance). The geographic, political, and migration contexts in both Ireland and Canada shape the ways these individuals relate to traditional performances and view their effectiveness in providing a sense of identity. The point in time when they left Ireland and arrived in Canada, and whether they originated from the Republic of Ireland or Northern Ireland played a significant role in the value they gave traditional activities.

These performances have been, and in many ways continue to be, a tool through which cultural and political identity is expressed. Specific cultural traditions have acquired deeply engrained associations with established sectarian divisions in Ireland. When there is an effort to neutralize the politics of performance for reasons of inclusiveness in Canada (as well as to reject the violence in Ireland, which reached its peak in the 1970s), tensions emerge concerning where the boundary between political and non-political lies. This manifests itself in disputes over which performances should be included in or excluded from the community's repertoire and, in the process, the choice to be apolitical becomes a profoundly political decision. 


\subsection{National narratives, multiculturalism, and migrant memories}

The individual narratives of the Irish Canadians I interviewed are a part of a wider collective memory of Irish history and diaspora. Scholarship on collective memory has long drawn on the work of the sociologist Maurice Halbwachs who has defined this phenomenon as a "body of remembrances" based on everyday communications through which individual memories relate to and are shaped by the shared narratives of a group. ${ }^{8}$ Conflict often produces contrasting narratives about the same event and can incite intense debates about what really happened and what it means. In his work on memories of General Augusto Pinochet's regime in Chile, Steve J. Stern has suggested a process of creating collective memory frameworks: narrative structures that individuals who lived through this period of Chile's history could access to frame their personal stories. These memory structures not only give meaning to the suffering they experienced but also work to legitimize their accounts, contributing to their political weight in a nation with several opposing collective memory narratives. For example, the story of a mother whose child was disappeared during the regime has greater political power when hundreds of mothers who have had similar experiences (which are also unique because of their specific circumstances) organize their individual stories to contribute to this narrative. Stern calls this an emblematic memory - a story that is not just about one person, but about "what

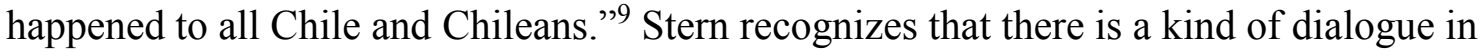
the process of collective remembering as contending memory frameworks are shaped and

\footnotetext{
${ }^{8}$ Direct quote from Maurice Halbwachs, The Collective Memory, trans. Francis J. Ditter, Jr. and Vida Yazdi Ditter (New York: Harper \& Row Colophon Books, 1980), 22. Also see: Jan Assmann and John Czaplicka, "Collective Memory and Cultural Identity," New German Critique 65 (Spring-Summer, 1995): 126-127.

9 Steve Stern, Remembering Pinochet's Chile: On the Eve of London 1998 (Durham: Duke University Press, 2004), 68.
} 
negotiated according to the needs of the individuals who contribute their stories to the collective. Forgetting is just as important as remembering in building memory frameworks and those personal stories that that do not contribute to the symbolic power of emblematic memories become what Stern terms "loose memories" fragmented and divorced from the larger narrative. ${ }^{10}$

The Irish Canadians I spoke with are living in the aftermath of long and pervasive colonialism and the traumatic division of Ireland into two states. They too are engaged in a similar process of collectively and individually negotiating memory frameworks that facilitate understanding their experiences of migration and their relationship with Ireland's past. Examining discussions of traditional performances can illuminate the tensions between memory frameworks, as music, writing, dance, and other cultural performances, all play a significant role in Ireland's larger collective memory.

The centrality of these cultural activities to the national narrative in the Republic of Ireland was apparent when I visited the National Wax Museum in Dublin. ${ }^{11}$ A whole floor of this museum is dedicated to the Time Vaults of Irish History, which promise to

\footnotetext{
${ }^{10}$ Ibid., xxvi-xxix, 1-3, 39-50, 68-69, 104-106, 113-124, 130-131. Paul Basu applies a similar concept in his study of Scottish heritage tourists. He found that genealogical tourists associate their ancestors' migration with difficult moments in Scottish history, particularly the Highland Clearances. Whether or not their antecedents left Scotland during that time period, many explained their family's emigration story in terms of that master narrative. Basu suggests that this is due in part to a pull to frame the Scottish migration narrative as a diaspora characterized by colonialism and exile. This also enables participants to develop a kind of subaltern identification and relieves them of the responsibility of living in nations founded on colonial expansion. Paul Basu, Highland Homecomings: Genealogy and Heritage Tourism in the Scottish Diaspora (London and New York: Routledge, 2007), 16, 178-179, 187-216.

${ }^{11}$ The National Wax Museum is privately owned. The current owner is music industry entrepreneur Paddy Dunning, which may explain the focus on music and the inclusion of sound recording equipment from various local musical studios. The museum was closed from 2005 until 2009 when it was relocated to the old Bank of Ireland and revitalized. See: Tourist Information Dublin, "The National Wax Museum, Dublin," accessed 23 July 2015, http://www.tourist-information-dublin.co.uk/the-national-waxmuseum.htm; Olga Aughey, "Paddy's waxworks," Westmeath Examiner, 17 June 2009, accessed 23 July 2015, http://www.westmeathexaminer.ie/news/mullingar/articles/2009/06/17/40795-paddys-waxworks; Shawn Pogatchnik, “Thieves raid Irish wax museum,” The Victoria Advocate, 30 July 2007.
} 
"take each visitor on a historical journey, from the Bronze Age period right up to the Good Friday Agreement including the Vikings, the Normans and the 1916 Rising." ${ }^{12}$ This part of the tour provides a particular narrative of Irish history that moves towards the eventual independence of the Republic of Ireland and greater autonomy from Britain for Northern Ireland.

The Time Vaults are bookended by the Writers Room, "a salute to the literary legacy of our nation's greatest writers,"13 and the Grand Hall of Fame, described as "The ultimate musical dedication to Irish rock'n'roll and film legends, including U2, Phil Lynott, Van Morrison and Colin Farrell."14 Along with wax statues of famous figures in the Hall of Fame, there is a video on loop that first describes the variety of Irish film stars and directors over the years and then focuses on the development of popular Irish music. This part of the film begins with the narrator explaining that "Music has been the fabric of Irish life. The music of Ireland has spread as far and wide as the Irish." ${ }^{15}$ It goes on to discuss the influence of various Irish artists, including Northern Irish musicians (Van Morrison) and American Irish groups (the Clancy Brothers). This has the effect of glossing over political and cultural divisions between Northern Ireland and the Republic and presenting music as something which transcends these tensions, ignoring the ways in which it has been used at times as a force to deepen these rifts. The museum also includes a recording studio where visitors are able to view and use equipment from well-known Irish studios. The format and structure of this museum demonstrates the significant place of these kinds of performances in Irish conceptions of identity and parallels the way some

\footnotetext{
${ }^{12}$ Museum brochure and map, The National Wax Museum Plus, Dublin, Ireland, 11 August 2014.

${ }^{13}$ Museum label, The Writers Room, National Wax Museum Plus, 11 August 2014.

${ }^{14}$ Museum brochure and map, The National Wax Museum Plus, Dublin, Ireland, 11 August 2014.

${ }^{15}$ Museum video, The Grand Hall of Fame, The National Wax Museum Plus, 11 August 2014.
} 
of my interviewees relate to and participate in these activities, particularly when they describe a need to connect with their Irish identity.

However, my interviewees are engaging with these performances and emblematic memories in the context of the Irish diaspora and their engagement with cultural activity takes on different meanings within the setting of Canada and, more specifically, Winnipeg. In this new space, the meanings of these activities are negotiated with other Irish Canadians as well as the wider host society when these performances are presented to other Canadians. When the majority of non-Irish people in this city encounter Irish music, they lack the nuanced understandings of performances and politics that insiders to the Irish community share.

This process of cultural adaptation can be understood as a negotiation of ethnicity. In this context, negotiation speaks to the relationships between immigrant groups and the dominant culture of the host society and provides a useful framework when thinking about how ethnic groups find ways to exist between two cultures. As societies are always faced with changing ideas and new pressures, both sides of this relationship are placed in the position of reinventing their identity to address their current needs. These shifting narratives may be relatively fluid but they are also grounded in historical relationships, cultural symbols, memories, and everyday social interactions. ${ }^{16}$

A prime venue for this kind of interaction between ethnic communities and other members of the host country in Winnipeg is Folklorama, an annual two week summer festival celebrating the different ethno-cultural groups in the city. The festival began in the context of multicultural policies introduced by Prime Minister Pierre Trudeau which

\footnotetext{
${ }^{16}$ Kathleen Neils Conzen et al., "The Invention of Ethnicity: A Perspective from the U.S.A.," Journal of American Ethnic History 29 (Fall, 1992): 4-6.
} 
encouraged non-threatening expressions of ethnic diversity. Folklorama was started in 1970 by the Folk Arts Council of Winnipeg Inc. and has steadily expanded over the decades. Communities set up pavilions across the city in church basements, schools, theatres, and the like. The groups may be delineated by nationality, ethnicity, language group, or geographic area. Such pavilions as the Africa Pavilion, Ethiopian Pavilion, Tamil Pavilion, and Israel Pavilion provide ethnic food, organize a showcase of traditional performances, set up information centres about the culture, and sell crafts. ${ }^{17}$ Scholars have critiqued the problematic essentialization and commercialization of cultures that occurs in cultural festivals like Folklorama. Neil Bissoondath offers a pointed critique of multiculturalism in general and argues that these kinds of events are superficial, synthetic, and depoliticized representations of cultures. ${ }^{18}$ However, it would be unfair to assume that the participants in these festivals, both performers and audience members, are unaware that the cultures on display are far more complex than presented.

Most interviewees who have been involved in Folklorama demonstrated a recognition of internal politics within the festival and the Irish pavilion, as well as what Tom called the "Hollywood Irish" aspect. ${ }^{19}$ Even so, there was a general positive consensus about their experiences in the festival. They recognized that one purpose was to entertain visitors, while still providing some educational material about Irish culture

\footnotetext{
${ }^{17}$ Cynthia Thoroski and Pauline Greenhill, "Putting a price on culture: ethnic organisations, volunteers, and the marketing of multicultural festivals," Ethnologies 23, no. 1 (2001): 189-209; Folklorama, "Find a Pavilion," accessed 06 August 2015, http://www.folklorama.ca/find-a-pavilion.

${ }^{18}$ Neil Bissoondath, Selling Illusions: The Cult of Multiculturalism in Canada (Toronto: Penguin Books, 1994), 82-84. Paul A. Bramadat reviews the critiques of cultural festivals, including Bissoondath's, and points out that within these critiques there is an assumption that there is an authentic culture that is being tarnished somehow by these events. He argues that Bissoondath is too dismissive and that there is a need for a more sensitive way to analyze the relationship between popular and ethnic culture - one that "resists the elitist tendency to quickly and categorically define what is and what is not an authentic depiction of a particular culture." Paul A. Bramadat, "Toward a New Politics of Authenticity: Ethno-Cultural Representation in Theory and Practice," Canadian Ethnic Studies 37, no. 1 (2005): 15-16.

19 Tom Naughten, interview by Kathryn Boschmann, Winnipeg, Manitoba, 19 June 2014, Part 2.
} 
and traditions. They also spoke of it as a chance to celebrate their culture and interact with other ethnic groups in a positive and safe setting. ${ }^{20}$ This is perhaps particularly valued when people have lived through a time and in a place when politically charged culture had the potential to lead to violence. Pavilion organizers try to present aspects of their culture in a way that is accessible and enjoyable to outsiders. Cultural intricacies are simplified and political tensions are downplayed or ignored entirely but participants are aware of and involved in the process. They make choices about how they want to present themselves to the wider community and governing bodies. All the while, there are considerable internal negotiations of culture, politics, and historical memory.

The Irish Association of Manitoba (est. 1972), or the Irish Club, is one space where members of the community mediate how the past will be approached and enacted, particularly because of its policy to remain non-political and non-sectarian. While there have been several Irish associations in Winnipeg during the post-war period (such as the Sons of Ireland and the Irish Protestant Association which were active in the 1950s and into the 1970s, and the Irish Canadian National Association of Manitoba which had a presence in the 1980s), the Irish Association of Manitoba appears to be the only one currently in operation. ${ }^{21}$ Like Folklorama, it was founded during a period when Canada was investing heavily in the idea of multiculturalism and there were a number of federal grants available to cultural associations. ${ }^{22}$ The majority of my interviewees were

\footnotetext{
${ }^{20}$ Joe and Mary Campbell, interview by Kathryn Boschmann, Winnipeg, Manitoba, 11 July 2014; Shirley Foamete, interview by Kathryn Boschmann, Winnipeg, Manitoba, 26 June 2014, Part 1.

21 "Ireland's Sons Celebrate," Winnipeg Free Press, 18 March 1955; "Irish Protestants Keep St. Patrick in Memory," Winnipeg Free Press, 18 March 1955; "Ethnic groups defend shows," Winnipeg Free Press, 11 August 1986; There was another Irish association present in Winnipeg when I began research for this project in late 2013 and early 2014. However, it appears to have shut down within the last year and information on its activities is no longer available.

${ }^{22}$ While there was considerable grant funding in the early years of Folklorama, this has declined significantly and participants have to compete for ever slimming resources. There is the potential to bring
} 
connected to, or at least familiar with, the Club and it came up in our conversations often. $^{23}$

Several interviewees also have had experience working with or taking in the productions of the Tara Players, a local amateur theatre company associated with the Club and established in 1973. The Players put on four to five productions every year and have their own theatre space in the Irish Club's facilities on Erin Street acquired in 1975. ${ }^{24}$ In addition to the Irish Club, Winnipeg is home to several Irish dance schools, including the McConnell School of Dance, the McDonnell School of Irish Dance, and the Brady Academy of Irish Dance. The city also has its own branch of Comhaltas Ceoltóirí Éireann, an Irish cultural organization that has spread across the globe.

\subsection{Irish nationalism, culture, and the state}

The history of the formation and presence of these organizations provides insight into the kind of atmosphere these interviewees entered when they settled in Winnipeg. As I have mentioned, understanding the context they left is crucial to understanding their relationship with these groups and the cultural activities they support. Ireland has a long history under British colonialism and the island's inhabitants continue to live with the effects. The English Crown had claimed authority over Ireland for centuries and increased its efforts to establish control and enforce assimilation in the early seventeenth

\footnotetext{
in a small profit from the pavilions but some organizers have questioned if the amount they bring in is worth the amount of work involved. Thoroski and Greenhill, "Putting a price on culture," 189-209.

${ }^{23}$ Jennifer Clary-Lemon, "WWe're not ethnic, we're Irish!': Oral Histories and the Discursive Construction of Immigrant Identity," Discourse Society 21, no. 1 (2010): 13-14; Eileen Baxter, interview by Kathryn Boschmann, Winnipeg, Manitoba, 04 July 2014; Tom Naughten, interview by Kathryn Boschmann, Winnipeg, Manitoba, 10 June 2014, Part 2.; Joe and Mary Campbell, interview by Kathryn Boschmann, Winnipeg, Manitoba, 11 July 2014.

${ }^{24}$ Irish Association of Manitoba, "Tara Players,” accessed 06 August 2015, http://www.irishassociation.ca/index.php/taraplayers; "A new cultural centre for Winnipeg's Irish" Winnipeg Free Press, 31 May 1975.
} 
century during and after the Reformation period. The Cromwellian conquest of the island solidified British rule over Ireland and the settlement of an Anglo-Scottish population reinforced the religious aspect of this colonial endeavour. ${ }^{25}$

The nineteenth century saw a gradual intensification of nationalist movements in Irish politics which were deeply connected with notions about Irish culture. ${ }^{26}$ This culminated in a Gaelic revival at the turn of the century which included a literary renaissance, the establishment of the Abbey Theatre, and renewed appreciation for Irish legends and oral histories. In addition, various organizations that continue to play a significant role in Ireland's cultural landscape were founded in this period. One such institution was the Gaelic League (established in 1893) which was primarily concerned with preserving and revitalizing the Irish language as well as supporting traditional musical activities through festivals and competitions. ${ }^{27}$

Some of these cultural organizations, including the League, initially attempted to be non-political in their activities (like the Irish Club in Winnipeg) and focus solely on the celebration of Irish culture. However, as Irish traditional culture was increasingly mobilized for nationalist causes and the categories of Catholic nationalist and Protestant unionist became entrenched, the institutions were associated more and more with political

\footnotetext{
${ }^{25}$ Stephen Howe, Ireland and Empire: Colonial Legacies in Irish History and Culture (Oxford: Oxford University Press, 2002), 21-30.

${ }^{26}$ These movements grew out of opposition to the Act of Union of 1800 which ended the Irish Parliament and placed Ireland under the rule of a united British state. The Great Famine (1845-1852) was seen by many in Ireland as a sign that this union was untenable. One major nationalist effort was the campaign to set up a system of Home Rule which would re-establish the Irish parliament without secession from Britain. This movement became a major political force by the 1870s and began to make headway in British Parliament around the turn of the century. Christine Kinealy, A New History of Ireland (Stroud, Glouchestershire: Sutton Publishing Ltd., 2004), 145-151, 161-215; Daniel Webster Hollis III, The History of Ireland (Westport, CT: Greenwood Press, 2001), 107-108.

${ }^{27}$ Kinealy, A New History of Ireland, 190; Hollis, The History of Ireland, 116-119; Dorothea E. Hast and Stanley Scott, Music in Ireland: Experiencing Music, Expressing Culture (New York and Oxford: Oxford University Press, 2004), 36-41.
} 
causes. $^{28}$ The League, which had strong connections with the Catholic Church, began to attract politically minded members and leaders who saw the organization's potential as a venue for the campaign for independence. Literary scholar David Pierce argues that the Gaelic Revival's turn to the past and celebration of traditional forms and stories was essential for Irish cultural nationalists, "who, under the twin emotionally charged principles of preservation and possession, transformed the enthusiasm of the antiquarian and academic interest into a more active engagement with the present."29

Performances are not only ways of expressing identity but also means of challenging power structures, and are often used to criticize the colonizers and empower resistance. Many colonial authorities have recognized the power of these activities as witnessed by their attempts to stifle them. For example, the government of Queen Elizabeth I declared that Irish musicians were "seditious and dangerous persons" and it was ordered that harpers be hanged and their instruments burned. ${ }^{30}$ Not surprisingly, appropriating traditional folk ways and encouraging pride in Irish heritage was seen as an effective way for nationalists to mobilize people to their cause and challenge the legitimacy of British colonial authority. This led to efforts to make the past and cultural heritage accessible and enjoyable - a central goal of the festivals organized by the Gaelic

${ }^{28}$ While there were certainly Protestant nationalists, as the conflict intensified, cultural nationalists increasingly viewed "Irishness" as Gaelic and Catholic. O'Shea, The Making of Irish Traditional Music, 18.

${ }^{29}$ David Pierce, "Cultural Nationalism and the Irish Literary Revival," International Journal of English Studies 2, no. 2 (2002): 8. The collection of and participation in cultural traditions (previously seen as backward by the upper classes) for nationalist purposes was part of a wider trend across Europe. Also see Catherine Foley, "The Notion and Process of Collecting, Recording and Representing Irish Traditional Music, Song and Dance: The Muckross House Collection," in Ancestral Imprints: Histories of Irish Traditional Music and Dance, ed. Thérèse Smith (Cork: Cork University Press, 2012), 108; Sean Williams, Focus: Irish Traditional Music (London and New York: Routledge, 2010), 70-72; Kinealy, A New History of Ireland, 190-193; Hollis, The History of Ireland, 116-120.

${ }^{30}$ Hast and Scott, Music in Ireland, 23; O’Shea, The Making of Irish Traditional Music, 7. 
League. In addition, these traditional performances became increasingly associated with nationalist politics and would become sites of historical memory struggles. ${ }^{31}$

Nationalist movements were eventually successful in establishing an independent Free State in the political south in 1922. However, six counties in the northeast part of Ireland were partitioned from the rest of the island in 1921 and established as the separate entity of Northern Ireland which continued as part of the United Kingdom under the British. These developments both shaped and were shaped by the growth of the various nationalist movements as well as the increasingly sharp divisions between Irish nationalists and unionists, particularly in the northern areas of the island. These conflicts would set the stage for the crises and continuing political tensions in the North and shaped the context of my interviewees' lives in Ireland. ${ }^{32}$ In particular, those from Northern Ireland demonstrated a significantly different relationship with traditional performance than those from the Republic of Ireland. While those from the South struggled to settle on which performances would be appropriate to include in a nonpolitical repertoire, the interviewees from the North expressed difficulty in identifying with traditional Irish performance in the first place. This disconnect from the repertoire was exacerbated by state efforts to distance Northern Ireland from Irish traditional culture, a point which will be explored further later in this chapter.

After independence, the Irish Free State, by contrast, established several cultural initiatives which indicated the national significance these activities were understood to have. For example, the Irish state developed its own broadcasting corporation (Radio Éireann) in 1926 and the Irish Folklore Commission was established in 1935 to collect

${ }^{31}$ O'Flynn, The Irishness of Irish Music, 6.

${ }^{32}$ Kinealy, A New History of Ireland, 145-151, 161-215; Hollis, The History of Ireland, 107-108. 
various forms of folklore. However, Ireland's economy suffered considerably from devastating events such as the Irish Civil War (1922-1923), the Great Depression, and the Second World War. The relatively new Irish state had difficulty modernizing its economy, and there was a steady stream of emigration. Rural areas - seen as wellsprings of Irish traditional culture - experienced large scale migration into urban centres and abroad. While some cultural activities received state support in these early years, others were disadvantaged by the enshrining of Catholic values in the Free State constitution. For example, the Public Dance Halls Act in 1935 restricted unlicensed gatherings, such as céilí dances, due to concerns about morality. ${ }^{33}$

During the 1950s traditional music received a boost from the rising popularity of ballads and folk music internationally. Interest in Irish folk music rose in North America and Britain before reviving in Ireland in the early 1960s. Music scholar Marion Leonard points out that Irish dance and musical performances have a special appeal to second and third generation Irish living abroad (specifically in Liverpool and Coventry). These performances are especially valued because they provide a sense of historical and intergenerational continuity and afforded opportunities for people with an Irish background to come together. In addition, many saw the physical act of playing music or dancing as a direct articulation of their connection with Ireland. Leonard notes that there is a pattern of British-born Irish being more involved in traditional cultural activities than their Irish-born counterparts who still live in the homeland. She suggests that there is not

\footnotetext{
${ }^{33}$ O'Shea, The Making of Irish Traditional Music, 31-33; Helen Lawlor, "Popularity and Revival: Factors Affecting Harp Reception in the 1950s and 1960s," in Ancestral Imprints: Histories of Irish Traditional Music and Dance, ed. Thérèse Smith (Cork: Cork University Press, 2012), 143; Hast and Scott, Music in Ireland, 41.
} 
the same need to establish identity for those living in Ireland. ${ }^{34}$ The displacement appears to increase the value of these activities as identity markers for those who choose to participate and can generate an exchange between the homeland and members of the diaspora similar to that of the 1950 s cultural revival.

Some of the early bands who played an important role in the revival included groups such as The Clancy Brothers (an Irish American group) and The Dubliners (a local Irish band) who played a significant role in the rise of traditional music in Irish popular culture. Possibly one of the most prominent figures in this music scene was Seán Ó Riada. Ó Riada viewed Irish music as an aspect of national culture that had managed to remain pure, despite the efforts of British colonialism, and he played a huge role in its promotion during this period. He not only organized and directed Ceoltóirí Chualann in 1959 - an exceptionally influential band which played a significant role in revitalizing traditional music and in reviving instruments such as the bodhrán - but also has been recognized for creating new social contexts and forms for Irish traditional music.

Ceoltóirí Chualann has been credited with elevating the status of this genre by presenting it effectively in a concert setting. Many of the founding members of this group went on to form The Chieftains, a band which has introduced many people to Irish folk music and which continues to influence traditional musicians. ${ }^{35}$

This period also saw the formation of several significant organizations, including the Arts Council of Ireland, a state organization which funds and promotes the arts, and Comhaltas Ceoltóirí Éireann in 1951. Comhaltas has a mandate to promote the Irish

\footnotetext{
${ }^{34}$ Marion Leonard, "Performing Identity: Music and Dance in the Irish Communities of Coventry and Liverpool," Social \& Cultural Geography 6, no. 4 (August, 2005): 516, 520.

${ }^{35}$ O'Flynn, The Irishness of Irish Music, 26-28; O'Shea, The Making of Irish Traditional Music, 47-49.
} 
language and traditional music and dance. ${ }^{36}$ In my interviews, both Tom and Maureen explained that the establishment of this organization was motivated by fears that the Irish language and musical traditions would die out if there were no formal structures to support them. ${ }^{37}$ Like the Gaelic League, Comhaltas organized major competitions among Irish musicians as a way to encourage interest and participation in cultural performances. These competitions, called fleadh cheoil ("festival of music") begin at the county level where prizewinners can go on to compete at the provincial stage and then, if they are successful, at the All Ireland competition (or Fleadh Cheoil na hÉireann). According to Tom and Maureen, these competitions not only help motivate participation in traditional performance, but also keep standards high. ${ }^{38}$ The organization has grown considerably over the years with branches all over the globe, and the All Ireland competition attracts hundreds of thousands of attendees every year. ${ }^{39}$

Comhaltas includes Northern Ireland in the All Ireland fleadh, but has strong nationalist leanings. Helen O'Shea, a scholar of ethnic music, argues that the statesupported organization "has been a powerful agent in co-opting selected rural musical practices and repertoires to become 'Irish traditional music,' emblematic of a unified national culture. ${ }^{\not 0}$ Musician and historian Fintan Vallely has criticized the organization's tendency to exclude Protestants and unionists through its rhetoric. ${ }^{41} \mathrm{He}$ disapproves of Comhaltas' use of music as a political tool, arguing that traditional culture

\footnotetext{
${ }^{36}$ Arts Council of Ireland, "Who we are," accessed 06 August 2015, http://www.artscouncil.ie/about/Whowe-are/; Lawlor, "Popularity and Revival," 143; Hast and Scott, Music in Ireland, 49.

${ }^{37}$ Maureen Taggart, interview by Kathryn Boschmann, Winnipeg, Manitoba, 17 June 2014, Part 2; Tom Naughten, interview by Kathryn Boschmann, Winnipeg, Manitoba, 19 June 2014, Part 2.

${ }^{38}$ Maureen Taggart, interview by Kathryn Boschmann, Winnipeg, Manitoba, 17 June 2014, Part 2; Tom Naughten, interview by Kathryn Boschmann, Winnipeg, Manitoba, 19 June 2014, Part 2.

${ }^{39}$ Hast and Scott, Music in Ireland, 49; O’Flynn, The Irishness of Irish Music, 26-27.

${ }^{40} \mathrm{O}$ 'Shea, The Making of Irish Traditional Music, 45-46.

${ }^{41}$ Fintan Vallely, Tuned Out: Traditional Music and Identity in Northern Ireland (Cork: Cork University Press, 2008), 85-86.
} 
should be apolitical. ${ }^{42}$ However, divorcing cultural performance from its provenance is not so simple.

\subsection{Leaving the Republic: Narratives from 1970s Irish immigrants}

The post-war cultural revival in the Republic was, in many ways, a response to the effects of colonialism. After centuries of British rule, celebration of traditional culture became more urgent and these performances were organized to instill pride in an identity once suppressed. ${ }^{43}$ The mobilization of these performances for nationalist causes became a part of their provenance. In the Republic of Ireland, the history of these performances can be viewed as a force for independence and participation in music, dance, festivals, and other cultural performance is encouraged by the state. In Northern Ireland, however, where the provenance of these activities made them politically inflammatory for most of the post-war period, many inhabitants (both Catholic and Protestant) intentionally distanced themselves from traditional performances. ${ }^{44}$ They did not have the same

${ }^{42}$ Comhaltas has also made strong political statements in the past. It took a strong stance in 1971 when it canceled the All Ireland competition to protest the mass internment without trial of several hundred Northern Irish nationalists. While Vallely recognized that many would see this as a reasonable response, it disappointed and upset many Irish Protestants and Catholics alike. Vallely, Tuned Out, 88.

${ }^{43}$ Pauline Greenhill studies English ethnicity in Canada and suggests English folk culture has a relatively small visible and public presence in comparison with other ethnic groups (such as Irish communities who often organize regular music sessions and, in the case of Winnipeg, have set up multiple dance schools). She points out that ethnicity is visible most when there are identifiable differences but as English culture forms a major part of mainstream culture in Canada because of its colonial history in the country, this culture and its traditions are easily absorbed. Groups in Canada desiring to connect with their heritage or who are attracted to English culture then enter into a process of ethnicity-making (drawing from Eric Hobsbawm's argument concerning the invention of tradition): selecting certain performances and cultural texts. She points to how in the rare cases when English identity is in a minority or threatened, providing Quebec as an example, "cultural expression and behaviour appears most clearly in its public social context." Pauline Greenhill, Ethnicity in the Mainstream: Three Studies of English Culture in Ontario (Montreal and Kingston: McGill-Queen's University Press, 1994), 4-5, 16-17, 25-27. Her observations point to a reason why cultures that have experienced colonial oppression resist its effects by celebrating and demonstrating pride in their culture. For those with English heritage, this kind of response is not necessary in the same way, especially in places where the British have played a major role as a colonial enforcer.

${ }^{44}$ It is worth noting that some people in Northern Ireland identify as British, rather than Irish. However, none of my interviewees chose to identify themselves in this way, although Eileen does mention this on $\mathrm{p}$ 
opportunities or, in some cases, the desire to forge personal connections with these pieces because of their political associations. Nor did Irish traditions enjoy active state support as they did in the Republic.

The provenance these performances acquired in Ireland plays a vital role in whether and how they are incorporated into the community's repertoire in Canada. The time and point from which individuals migrated are also significant in how they relate to this repertoire (as are gender and class - both important aspects of these interviews and of performance, and worthy of greater attention than I have space to give them). ${ }^{45}$ The majority of the interviewees originated from the Republic of Ireland and a comparison of their interviews offers insight into the differences and tensions within this particular group. Those interviewees who originated from Northern Ireland provided a provocative contrast and further illuminate the complex relationship between traditional performances, their political history, and their place within the Irish community in Winnipeg. ${ }^{46}$

Personal context is crucial to understanding the differences and similarities between the role of cultural activities in my interviewees' pre-migration experience and their expression of identity. For example, when Maureen was a young girl, she was encouraged to participate in Comhaltas competitions by Sylvester Conway, a principal

78. While Eileen (and, to a certain extent, the stories she and Tom shared about Ralph and Heather) represents an Ulster Protestant perspective, it is worth noting that the majority of the perspectives examined here are from those who are generally supportive of a unified Ireland.

${ }^{45}$ For more on gender and class see: Lawlor, "Popularity and Revival," 143-158; Róinín Nic Dhonncha, "Sean-nós Singing: Ideological Perspectives on a Native Art," in Ancestral Imprints: Histories of Irish Traditional Music and Dance, ed. Thérèse Smith (Cork: Cork University Press, 2012), 159-167; Leith Davis, Music, Postcolonialism, and Gender: The Construction of Irish National Identity, 1724-1874 (Notre Dame, IN: University of Notre Dame Press, 2006).

${ }^{46}$ Interviewees from the Republic of Ireland include Joe, Mary, Shirley, Pat, Tom, Brian, Maureen, and Catriona. The two interviewees from Northern Ireland are Eileen and Greg, both of whom are from Belfast. 
member of the organization who was working as a school teacher in the village of Cappawhite, Tipperary, close to where Maureen lived..$^{47}$ He had heard that she was an Irish dancer and was delighted to find she could sing as well. She had picked up singing from her grandfather (a central figure in her childhood who died when she was seven years old) and remembers learning new songs by listening to the radio as well as taking classes in school that taught the traditional sean-nós style. ${ }^{48}$ After a great deal of hard work and careful balancing of school and singing, Maureen won the 1965 Comhaltas AllIreland competition in the sean-nós category - a coveted prize and a sign of excellence in the style. She explained to me, "I suppose, without being too dramatic about it, it was a life changing thing." 49 Winning the All-Ireland would open many doors for her including invitations to perform and teach. These invitations facilitated her entrance into communities in both Ireland and Canada. She would go on to be instrumental in the formation of the Winnipeg branch of Comhaltas in the 1970s and is still involved in its operation. $^{50}$

While traditional performance certainly played a significant role in Maureen's life, it is important to note that she was raised in rural Ireland in the Republic, where Irish culture had a relatively continuous and stronger presence than in urban settings. The

\footnotetext{
${ }^{47}$ Gerry Slevin, "In the Footsteps of Cusack," Treoir 17, no. 2 (1985): 16.

${ }^{48}$ Maureen Taggart, interview by Kathryn Boschmann, Winnipeg, Manitoba, 30 June 2014. Sean-nós translates as "old style" and refers to one of the oldest forms of song and dance. In song, sean-nós is unaccompanied, highly ornamented, usually sung by a solo artist, and typically reserved for more intimate performances. Maureen explained that these songs are typically passed down through oral tradition and the singer will adapt a song to their own preference and the occasion. Songs in the sean-nós style are sung in Irish or English, although Maureen believes that in order to be true to the tradition songs should be sung in Irish. Tim Rutherford-Johnson, Michael Kennedy, and Joyce Bourne Kennedy, eds., The Oxford Dictionary of Music, $6^{\text {th }}$ ed., s.v. "sean-nós" (Oxford: Oxford University Press, 2012). For more about Maureen's grandfather, see: http://beingirishontheprairies.ca/\#!/my-grandfather-was-a-very-interesting-nere-do-wellhe-was-great

${ }^{49}$ Maureen Taggart, interview by Kathryn Boschmann, Winnipeg, Manitoba, 17 June 2014, Part 2.

${ }^{50}$ Maureen Taggart, interview by Kathryn Boschmann, Winnipeg, Manitoba, 17 June 2014, Part 3. Tom Naughten and his wife, Heather, were also founding members of the Winnipeg branch.
} 
distinction between urban and rural experiences of traditional culture in the $1950 \mathrm{~s}, 60 \mathrm{~s}$, and 70s was explained to me by Joe and Mary when I asked whether they participated in Irish cultural activities when they were growing up. Joe, who is from Dublin, went to a Christian Brothers school where instruction was completely in Gaelic and where participation in Irish sports, such as Gaelic football or hurling, was encouraged. However, he told me that he and his friends would not be caught dead participating in traditional performance activities because, "At that time, it was not cool to be-to do Irish stuff." ${ }^{.51}$ At this, Mary jumped in to explain that there is an important difference between urban and rural people in Ireland. She grew up in Nenagh, County Tipperary, where it was common for community members to get together to sing and play Irish ballads, rebel songs, and the like. ${ }^{52}$

This difference was also apparent to her in the song choices that were made when she would meet with Joe's family. "Joe's family would always sing the old music hall numbers. Uh, you know, Champagne Charlie is My Name all those ones they would know. Me, they'd be saying, 'Sing-sing Are ye Right There, Michael, Are ye Right' about the West Clare Railway." 53 Joe agreed that there was a difference, explaining that, while it was common for people in Dublin to gather together and sing, the songs were mostly "non-Irish." ${ }^{54} \mathrm{He}$ suggested that this might have to do with how "Dublin was very much under the British. Maybe people became self-conscious about being Irish, because it was

\footnotetext{
${ }^{51}$ Joe and Mary Campbell, interview by Kathryn Boschmann, Winnipeg, Manitoba, 11 July 2014.

${ }^{52}$ Ibid.

${ }^{53}$ Ibid.

${ }^{54}$ Ibid.
} 
seen as the poor. Anything Irish-yeah, there was-there was an inferiority complex actually about it." 55

The attitude Joe and Mary describe concerning traditional music in Dublin seems to have continued to a certain extent in urban centres in Ireland. While visiting Limerick in 2014, I spoke with genealogist and historian Sharon Slater. She explained that there are areas that have traditional music nights for locals, but most pubs include them to bring in tourists. This confirmed the impression I had of Temple Bar in Dublin, an area with many tourists and where every pub advertised a traditional music night. Sharon also mentioned that while children have to learn performances such as traditional dance in school, many of them hate it, "especially the boys!" 56 However, there were also some moments when Dublin inhabitants demonstrated appreciation for Irish music as a kind of guilty pleasure. For example, as I checked into my hostel, I noticed the man who was helping me (who had what seemed to be a Northern European accent) was listening to a traditional Irish tune. His co-worker leaned over and said in an Irish accent, "You're listening to that stuff!" At this the man immediately turned off the music and rolled his eyes at his coworker, who laughed and said, "It's catchy, isn't it?"

For people originating from rural areas, like Mary and Maureen, participation in traditional performance in Canada was a continuation of activities they already enjoyed in Ireland. Maureen left Ireland because her husband got a job teaching in Winnipeg. It was

\footnotetext{
${ }^{55}$ Ibid. Joe's comment points to a tendency in Ireland to view Dublin as being less Irish because of its position as a colonial administration center as well as its location on the eastern coast. However, several important organizations that support traditional performances originated in Dublin. This also speaks to the kind of class influences at play in the promotion of traditional music which was mostly a middle and upper class pastime, contrary to the image of being primarily a rural working class activity. O'Flynn, The Irishness of Irish Music, 190; Hast and Scott, Music in Ireland, 49; Lawlor, "Popularity and Revival," 143145; O'Shea, The Making of Irish Traditional Music, 31-32.

${ }^{56}$ Sharon Slater, interview by Kathryn Boschmann, Limerick, Ireland, 17 August 2014.
} 
a difficult development for her because, as she told me, "I loved Ireland very much, and I loved my life there, and I loved Irish culture, and I loved the people, and loved everything about it. ${ }^{" 57}$ Her first two years in Winnipeg were characterized by loneliness and homesickness. "I found that I was so desperately lonely and, um, I felt like a misfit. And I was desperately unhappy. I was happy with my job. Um, but I suppose I really didn't want to be here. I wanted to be in Ireland. And so, I just had a talk with myself and said 'Well, you know you're here. You've got to try to do something about it."

What she chose to do was pursue her interests in drama and, later, music. She explained she was hesitant to join an Irish group for fear of isolating herself from other Canadians, but despite this tentativeness, she was soon tremendously involved in various Irish cultural activities in Winnipeg. ${ }^{59}$ She contributed to the establishment of the Tara Players, taught sean-nós singing, and, as already noted, played a key role in the founding and operation of the Winnipeg branch of Comhaltas. When I asked her why she changed her mind about participating in the activities of Irish groups, she explained, "I think what I was doing was pursuing, you know, Irish culture. [...] It wasn't so much because it was an Irish group that I joined them. It was just that they were doing things that I liked to do. ${ }^{{ }^{60}}$ For Maureen, these activities had long been enjoyable pastimes and a significant part of her life in Ireland. Similarly, Mary explained to me that, "I think it was always a

\footnotetext{
${ }^{57}$ Maureen Taggart, interview by Kathryn Boschmann, Winnipeg, Manitoba, 17 June 2014, Part 2. ${ }^{58}$ Ibid.

${ }^{59}$ Maureen Taggart, interview by Kathryn Boschmann, Winnipeg, Manitoba, 17 June 2014, Part 2. Maureen was not the only interviewee to mention this concern. Eileen explained that she thought it was important to integrate when she settled here. Brian told me that, while he never let go of being Irish, he went through a period where he felt it necessary to adapt and Canadianize as much as he felt comfortable. Eileen Baxter, interview by Kathryn Boschmann, Winnipeg, Manitoba, 04 July 2014; Brian Richardson, interview by Kathryn Boschmann, Winnipeg, Manitoba, 18 July 2014, Part 1.

${ }^{60}$ Maureen Taggart, interview by Kathryn Boschmann, Winnipeg, Manitoba, 17 June 2014, Part 3.
} 
part of who we were, in a way. Our culture." ${ }^{61}$ She elaborated on this to explain that she and Joe did not exactly rush out to find all things Irish, but they enjoyed it and would make a point of seeing visiting Irish performers, if they could. ${ }^{62}$ Pursuing Irish cultural performance in Canada was more about participating in what they enjoyed and valued about their Irish identity than it was about searching out an Irish community.

Both these women are well versed in Irish history and understand the political role of music and performance. For example, when Joe was explaining how patriotic the Christian Brothers were, Mary stepped in to point out, "Well, that-that started in early 1900s $[\ldots]$ when there was that huge cultural revival which always precedes revolution, doesn't it?" ${ }^{93}$ Maureen shares this kind of historical sensibility and has strong views on what constitutes authentic Irish performance. She described how she believed sean-nós should be performed, explaining that "the true sean-nós-and I'm-as I say, I'm a stickler for the-for the real tradition. The true sean-nós is an individual performer, um, singing on his or her own, in his or her own style, which is picked up from the ancestors." 64 These moments in our conversations point to a deep connection and strong engagement with the historical and political significance of the Irish community's shared cultural repertoire.

The Irish Canadians that I spoke with who originated from more urban areas typically share this engagement, but their relationship with traditional Irish performance took a different trajectory. In contrast to Maureen and Mary, Tom and Joe (and to a certain degree, Brian) seem to have felt a greater draw to these activities after they left Ireland. Despite his original attitude towards Irish music as a child and young adult, Joe

\footnotetext{
${ }^{61}$ Joe and Mary Campbell, interview by Kathryn Boschmann, Winnipeg, Manitoba, 17 July 2014.

${ }^{62}$ Ibid.

63 Joe and Mary Campbell, interview by Kathryn Boschmann, Winnipeg, Manitoba, 11 July 2014.

${ }^{64}$ Maureen Taggart, interview by Kathryn Boschmann, Winnipeg, Manitoba, 30 June 2014.
} 
later became one of the founding members of the Irish Club. For many years he acted as the Vice President of Culture, the Club choir director, and a member of a local ballad group called The Irish Stew (which Brian joked would be "the Irish Stewed" at the end of a night of singing). ${ }^{65}$ When I asked Joe what motivated him and the other organizers to start the Club in Winnipeg he answered, "I believe we felt a sense-you needed a sense of identity here. To give-to give you your own identity as Irish. [...] And we felt, well, what do we all have in common? [...] So let us, almost import some of Ireland here through drama, through the choir, through The Irish Stew-the group. So, that's what it was. Honest to goodness. Just to feel a sense of belonging in a foreign country, really." ${ }^{66} \mathrm{He}$ went on to explain, "You're not interested in joining an Irish Club in Dublin, that's for sure! And who cares, you know? Yeah, you may go to an Irish play, and you may not. But who cares? It doesn't matter. Um, because you're not special in Ireland when you're Irish. [...] There's four million of you, you know. So, whereas here, it's extraordinary sometimes!" ${ }^{97}$ For Joe the feeling of dislocation changed the way he saw and related to Irish culture. Migration produced a feeling of being foreign and created a need to meet with other people who shared his cultural repertoire. Those activities that previously were "uncool" became an avenue for community building among Irish Canadians. ${ }^{68}$

\footnotetext{
${ }^{65}$ Joe and Mary Campbell, interview by Kathryn Boschmann, Winnipeg, Manitoba, 11 July 2014. "A new cultural center for Winnipeg's Irish," Winnipeg Free Press, 31 May 1975. Brian Richardson, interview by Kathryn Boschmann, Winnipeg, Manitoba, 18 July 2014, Part 1.

${ }^{66}$ Joe and Mary Campbell, interview by Kathryn Boschmann, Winnipeg, Manitoba, 11 July 2014.

${ }^{67}$ Ibid.

${ }^{68}$ It is worth noting that when we talked about popular traditional Irish artists, Joe explained to me that he would go see them but said, "I wouldn't be, however, climbing over sharp objects to get to see them or hear them, you know?" He attributed this to the amount of time he spent outside of Ireland, particularly in Italy and India. However, his involvement in the Club demonstrates there was still a significant draw to tradition and culture. It may be that this more intimate setting and inclusive type of performance filled a need that those more impersonal concerts could not. Joe and Mary Campbell, interview by Kathryn Boschmann, Winnipeg, Manitoba, 17 July 2014. For more on the draw of traditional music for Joe and Mary, see: http://beingirishontheprairies.ca/\#!/weve-had-wonderful-times-2.
} 
Tom's experience of Irish traditional performance is similar to Joe's in several ways. Although he was interested in music as a teenager and young adult, he never played traditional tunes. The songs were always in the background and sometimes he might sing some of them at parties, but it was never something he actively sought out. As he explained at one point in our conversation, "I mean, I'm a young kid; you don't think much of your heritage. It's just your heritage. It was just there." ${ }^{99}$ This changed for him after he spent several years studying in British Columbia and working in the Yukon Territory. He explained,

T: I had no way to be Irish. I had no way to hang onto my culture. And so I started listening to, um, traditional Irish music. I had heard some amazing stuff my last couple of years in Ireland. Planxty was a band that came out. The Chieftains were starting to come out. A guy called Seán Ó Riada.

$\mathrm{K}$ : Yeah.

T: Um, I had gone to a concert in-in-at the university, purely by accident. And a guy called Seán Ó Riada was playing. [...] And he showed how the ancient music was transformed off harpsichord, how it was played on the harpsichord, how it sounded, and then how it was transferred onto piano and how it sounded. [...] And I was-I was totally stunned. I didn't know who Seán Ó Riada was. I didn't know he was probably one of the most eminent musicians in Ireland at that time. [...] And a magnificent classical performer. But he was really interested in Irish music and so out of the work and the research that he did, The Chieftains came. [...] And-and so, um, I'd heard his early-Seán Ó Riada's early stuff and I had heard the Chieftains' early stuff. And I went, "Oh, that's neat stuff." But then left it.

K: Yeah.

T: And then went back to it when I was looking for...

$\mathrm{K}$ : Something.

$\mathrm{T}$ : ...some cultural thing to hang my hat on. I went back to music. ${ }^{70}$

This anecdote illustrates not only the significance of migration in Tom's

relationship with traditional music but also the importance of the cultural context in

Ireland. The revival of the 1950s had taken root and had a significant effect on peoples'

experience of traditional music in their everyday lives. The rise of Ó Riada and bands like

${ }^{69}$ Tom Naughten, interview by Kathryn Boschmann, Winnipeg, Manitoba, 19 June 2014, Part 2.

${ }^{70}$ Tom Naughten, interview by Kathryn Boschmann, Winnipeg, Manitoba, 19 June 2014, Part 1. 
The Chieftains re-energized interest in traditional music and reinforced its connection to Irish nationalism. ${ }^{71}$ The exposure Tom had to this music before he left Ireland in the 1970s established it as a constructive way to maintain a sense of Irish identity while in Canada.

It is also important to note that, like Joe, Tom recognizes that culture fulfills a purpose. Its ability to attract and provide a ready-made community with a shared cultural repertoire was a significant part of traditional music's appeal for him. At the time of our interview, Tom's oldest son Kevin and his girlfriend Kaitlin - who are both talented musicians engaged with Irish traditional music - were preparing to move to Australia. While Tom was (and still is) supportive of his son's decision, it was clearly an emotional topic for him. He saw this as a way to "pay his dues" since his parents went through a similar experience when he left for Canada. He expressed concern that his son might become torn between the various aspects of his cultural identity, explaining, "[Kevin will] be a Canadian with Irish heritage in Australia. And he'll have three parts to him. I've got two. My dad had one."’72

However, he took comfort in knowing that Kevin and Kaitlin's interest in music would provide them with a community in Australia. He told me, "it doesn't matter where you are in the world. Kevin and Kaitlin go to Australia. [...] There's two sessions in Sydney that are on. Formal sessions. They go to both of them. They met forty people in two nights. You know, they got their phone numbers, they got their emails, the whole lot... playing music. It doesn't-it doesn't matter where I go in the world, I will look up to

\footnotetext{
${ }^{71}$ O'Flynn, The Irishness of Irish Music, 26-28; O'Shea, The Making of Irish Traditional Music, 47-49.
}

72 Tom Naughten, interview by Kathryn Boschmann, Winnipeg, Manitoba, 19 June 2014, Part 2. 
see who's doing what." ${ }^{, 73}$ As this story illustrates, the community building capacities of music, on both a local and international level, become particularly significant for people during emotionally difficult times. Traditional music sets up the scenarios which enable participants to connect with others who share similar interests and a familiar cultural repertoire. This can give considerable comfort when people are facing major adjustments.

Brian has written a play entitled Now You Are Everywhere based on his experiences of busking on the Cliffs of Moher. This piece captures the stability provided by music and the community it fosters. He had returned to Ireland to care for his dying mother and, shortly after moving, his marriage broke up. This was an extremely difficult time for him and he recently chose to dramatize the experience. Music is given a central place in the play, partly because it is the livelihood of Rich E., the primary character. It also is used as a tool to illustrate themes of multiculturalism, migration, and identity. For example, one of the main characters is from Nigeria and, on several occasions in the stage direction, there is a combination of African drum and Irish tin whistle. At a climactic point in the play, Rich E. has been informed of the death of his mother and is struggling with the continued separation from his children. He stands on the edge of a cliff, arms spread, looking down at the water below (a terrifying sight, as anyone who has visited the Cliffs of Moher will know). A friend and fellow busker named Michilin finds him and gently coxes him back to safer ground. Significantly, Rich E. only begins to walk away from the edge of the cliff when Michilin invites him to play with his band in an upcoming gig. ${ }^{74}$ Music here reminds Rich E. of who he is, that he has a supportive

\footnotetext{
${ }^{73}$ Ibid.

${ }^{74}$ Brian Richardson, "Now You Are Everywhere," (unpublished play, 2014, courtesy of the author), Word file.
} 
community network, and offers him a way out of the dark place in which he has found himself.

As well as acting as a tool to ground individuals and communities with a sense of identity, these performances also serve to distinguish participants as Irish in Canada to both insiders and outsiders. As Joe pointed out and as Leonard notes in her work, there is not the same need to do this in Ireland, where the majority of the population share a culture. ${ }^{75}$ Outside of Ireland, being Irish and participating in Irish traditions takes on a different kind of significance. Tom told me a story about a flight from Amsterdam to Toronto where a fellow passenger saw his bodhrán case and asked "Do you play that joke?" Tom replied in the affirmative and soon the two of them, along with a few other Irish musicians on the plane, put on a small impromptu concert, much to the delight of the other passengers. At the end of this anecdote, Tom said, "But that sort of stuff happens all the time to traditional music-And I bet it happens for, you know, for-for Ukrainians, for any other tradition and it happens." "76 Tom's comment at the end of his story points to the significance of traditions and their ability to produce a shared (and portable) repertoire as well as the boundary demarcation signalled by cultural performances. In this anecdote, music - or the possession of a traditional instrument identifies the musicians to each other. ${ }^{77}$

These actions can signal belonging to a certain community, while, at the same time, defining boundaries of who does not share that repertoire. Naturally, creating and sustaining a community is not just about bringing people together; it is also about

\footnotetext{
75 Leonard, "Performing Identity," 520.

76 Tom Naughten, interview by Kathryn Boschmann, Winnipeg, Manitoba, 19 June 2014, Part 2.

${ }^{77}$ For more on Tom's view of music, see: http://beingirishontheprairies.ca/\#!/tom-and-it-brings-you-home
} 
creating an identity that distinguishes them from others. Communities invariably define what separates them from other groups of people. They establish certain codes of behaviour and necessary knowledge required for someone to become an insider to the community. ${ }^{78}$ The knowledge of traditional tunes, how the instruments should sound together, and acceptable ways for musicians to relate to each other, open communication between people who share that knowledge. Insiders will be able to recognize the scenario that is being established (a gathering of traditional musicians) and can chose whether or not to activate the repertoire (joining into the music or refraining). While outsiders are usually welcome to listen, watch, and appreciate, they cannot fully join in without having taken the time and effort to learn at least part of the repertoire. Some communities may be welcoming of newcomers and not terribly strict in their boundary enforcement, but limits are still required if a community desires to keep a distinct identity. There are times, however, when boundaries are fiercely maintained and fault lines become violent, as was the case in Northern Ireland during the Troubles.

\subsection{A new immigrant cohort addresses the politics of difference}

As contexts change and people's needs shift, culture will often adapt to fulfill new requirements and the boundaries will adjust. This was something that several interviewees recognized in our conversations. While talking to Tom about the different activities people participate in and consume to feel Irish, some of which could be labelled kitsch, Tom explained, “There are people who get very upset. Um, but they're being wholly Irish in their own way. It's not-it's not sacred. It's not sacrosanct. [...] You know,

\footnotetext{
${ }^{78}$ Conzen, et al., "Invention of Ethnicity," 13, 22-23; Royden Loewen and Gerald Friesen, Immigrants in Prairie Cities: Ethnic Diversity in Twentieth-Century Canada (Toronto: University of Toronto Press, 2009), 3-9.
} 
it's a culture. It lives. It's organic. It has a life of its own. And if you don't respect that it's going to change and live and morph and move along, then you're-you're daft. You know?"79

A similar idea was also expressed by Joe and Mary when we were discussing how the Irish Club has developed over time in terms of activities and members' expectations. Mary pointed out, "But a lot of that has to do with changing times, if you like. Like, since the Riverdance and the Celtic Tiger, Ireland has become mainstream. When we came here first, if you heard two songs on St. Patrick's Day you cried your eyes out, because that's about all you'd hear. Whereas all of a sudden it became very mainstream. And [Joe is] right in a sense, that that's sort of the death knell to places like the Irish Club, if you like, where they don't-there's nothing fresh to offer anymore because it's already out there." ${ }^{\prime 0}$ Joe agreed and explained further that the Club offered "a way for us to keep together, get together, be with each other, share our- our culture with each other. [...] But that-but that fulfilled its purpose for us. Now, the next generation so-are getting into it to some degree. But it'll have to reinvent itself because it has a different function." ${ }^{\prime 1}$ Joe and Mary both recognize that the Club, and the performance activities it has supported, filled a need for their community at a particular point in time. As new generations of Irish immigrants settle in Winnipeg, the Club will have to adjust to fill a new set of needs or cease to be relevant to the community.

This recognition agrees with Taylor's observations on repertoire: "the actions that are the repertoire do not remain the same. The repertoire both keeps and transforms

\footnotetext{
${ }^{79}$ Tom Naughten, interview by Kathryn Boschmann, Winnipeg, Manitoba, 19 June 2014, Part 2.

${ }^{80}$ Joe and Mary Campbell, interview by Kathryn Boschmann, Winnipeg, Manitoba, 11 July 2014.

${ }^{81}$ Ibid.
} 
choreographies of meaning." 82 The repertoire transmits communal memories and knowledge but it is also mediated through the performers. There is a process of selection which considers the needs of the participants. ${ }^{83}$ As a new generation of Irish Canadians enters the Club, they access the repertoire according to their needs and perhaps shift some of the established boundaries.

In some ways, Shirley, who moved from Cork to Manitoba in 2012 and is the most recent Irish Canadian of the interviewees, represents a new generation accessing the Club. Traditional music was a part of her everyday life in Ireland, as it had been for Maureen and Mary: traditional dance and song, including music in the sean-nós style, were a part of the school curriculum for both herself and her sons (although not to the same degree as it had been in the 1960s when passing an Irish language exam was required in order to graduate).$^{84}$ Music was also a part of social life in Ireland while she lived there, where, "at the end of a party or the end of a night it was always singing. We always ended up singing. That's definitely part of the Irish culture. [...] Oh yeah, like, last- last week we went to a party. A fortieth birthday party for one of the Irish girls from the Irish Club. And, like, by twelve o'clock, we're all singing. Everybody picks a different song and they'll sing it." ${ }^{85}$ At the same time, Shirley explained that she is more drawn to traditional Irish music in Canada than she was in Ireland, in part because of her involvement with the Irish Club. She was introduced to the Club by her sister and since

\footnotetext{
82 Taylor, The Archive and the Repertoire, 20.

83 Ibid., 20-21.

${ }^{84}$ Having to pass Irish in order to graduate was a point brought up consistently by nearly every interviewee from the Republic of Ireland who went through the Irish school system and left in the 70s. This is another example of a state initiated program in the Republic to generate an appreciation for traditional culture.

${ }^{85}$ Shirley Foamete, interview by Kathryn Boschmann, Winnipeg, Manitoba, 26 June 2014, Part 1.
} 
then has volunteered her time to help out with club events, act as Master of Ceremonies at the Club's pavilion at Folklorama, and perform in several Tara Player productions.

While she has a deep appreciation for the Irish Club, its activities, and the community there, she has found there are points that do not align entirely with her perspective on Irish culture and history. It is common for separate waves of immigrants from the same point of origin to have varying understandings of past events and their political significance due to their different historical contexts. ${ }^{86}$ Tom noted this trend in the Irish Club and told me, "the people I know that immigrated during the Troubles and the people who immigrated after the Troubles and the people who immigrated after, um, the-the Celtic Tiger success, during that or after that now they're coming over. Very different attitudes. Very different." 87 This geographical and historical context shapes the boundaries of collective memory frameworks within these groups and there is a process of internal negotiating as to how community members from different waves will engage in cultural activities and the politics of the homeland. As a part of a generation with greater distance from the most intense years of the Troubles, Shirley has had less direct experience of this conflict in comparison to those growing up in Ireland during the 1960s and 70s.

This seems to have contributed to difficulties she had with a few of the Club's policies, particularly concerning their stance on rebel songs. These tunes are politically charged and because of this they have been, and still are, discouraged in the Irish Club in

\footnotetext{
${ }^{86}$ Royden Loewen, "The Poetics of Peoplehood: Ethnicity and Religion among Canada's Mennonites," in Christianity and Ethnicity in Canada, ed. Paul Bramadat and David Seljak (Toronto: University of Toronto Press, 2008), 330-364; Hikmet Jamil, Sylia C. Nassar-McMilan, and Richard G. Lambert, "Immigration and Attendant Psychological Sequelae: A Comparison of Three Waves of Iraqi Immigrants," American Journal of Orthopsychiatry 77, no. 2 (2007).

${ }^{87}$ Tom Naughten, interview by Kathryn Boschmann, Winnipeg, Manitoba, 19 June 2014, Part 2.
} 
an effort to maintain its non-political and non-sectarian mandate. ${ }^{88}$ While we talked about this policy, Shirley explained to me, "You know, it's-it's a long time ago since Ireland has its freedom. [...] Like, that's at least 3 or 4 generations of people. Surely you should be... but it's-it's not done. It's not done. You know? But I mean, it's supposed to be an Irish Club. And if you can't sing Irish songs in an Irish Club then something's not quite right.",89

Like the issue of rebel songs, the display of the Irish flag has come up on a few occasions in the Club's history. Flags act as a symbol of identity and have a particular provenance with political significance. The discussion of the Irish tricolour as it arose in my interviews points to the different ways people relate to this provenance. These conversations provide insight into the debates around what symbols and performances should be included in the community's cultural repertoire. This issue arose in 1987 when a group of Irish nationals funded a visit from an executive member of Sinn Féin to Winnipeg. ${ }^{90}$ Some claimed the visit was intended to raise funds for the Irish Republican Army (IRA) while others viewed this action as a sign of support for the fight against British rule in Northern Ireland. Aidan O'Brien, a founding member and the first president of the Irish Association of Manitoba, outlined the Club's position on this issue in the Winnipeg Free Press: he explained how the goal of the Irish Association of

\footnotetext{
${ }^{88}$ The mandate is discussed in the Introduction, $\mathrm{p} 22$. The Club's mandate was been publicized in newspapers and on its website where it explains that the Club "owes its success to its founding principles of being non-sectarian, non political [sic] and not-for-profit." The Irish Association of Manitoba, "About Us," accessed 5 August 2015, http://www.irishassociation.ca/index.php/aboutus; Aidan J. O’Brien, letter to the editor, "Irish Association," Winnipeg Free Press, 24 January 1973; "Irish Association Formed," Winnipeg Free Press, 28 November 1972. The mandate appears to have been decided upon by the Club's founding members and is maintained by its members.

${ }^{89}$ Shirley Foamete, interview by Kathryn Boschmann, Winnipeg, Manitoba, 26 June 2014, Part 1.

${ }^{90}$ A nationalist political party which, at this point, had strong ties with the IRA and fiercely campaigned for the separation of Northern Ireland from the United Kingdom. Arthur Aughey, "Political Parties: (2) Structures and Platforms," in Northern Ireland: Politics, eds. Arthur Aughey and Duncan Morrow (London and New York: Longman, 1996), 74-83.
} 
Manitoba was to achieve a middle ground and to show how all Irish people can live together in peace. Accomplishing this required a fairly precarious balancing act of avoiding politics without seeming to simply be ignoring the deadly struggle in Ireland.${ }^{91}$ This debate also drew attention to the Club's choice not to display the Irish tricolour flag and refrain from singing the national anthem in an attempt to depoliticize the space, a point which some other active Irish associations in Winnipeg criticized at the time. ${ }^{92}$

The policy on the flag has raised some questions from within the Association as well as from outsiders. Rather than display this national symbol, the Club chose to create stained glass windows representing the less contentious emblems of the four provinces of Ireland: Connacht, Leinster, Munster and Ulster. ${ }^{93}$ Also included in the artwork on the Club's walls is a series of metal-works depicting various symbols representing important aspects of Irish history, accompanied by short written accounts explaining their significance. This includes representations of St. Patrick, the Vikings, a map of the two states of the Republic of Ireland and Northern Ireland, and the Union Jack. There is no text provided to explain the inclusion of the Union Jack, but the description that accompanies the map explains the significance of English oppression in Irish history. ${ }^{94}$ Shirley mentioned the inclusion of the Union Jack in our interview with a certain amount of exasperation. While it is understandable that the artist decided to include this image to

\footnotetext{
91 “Winnipeg’s Irish war with words" Winnipeg Free Press, 19 November 1987.

${ }^{92}$ Ibid. Dermot Rooney, the president of the Irish Canadian National Association of Manitoba, was one such critic. He arrived from Dublin in 1970 with his family and worked with others to form this association in 1983. "Irish leader sets out to change toadstood-bar stool image," Winnipeg Free Press, 20 December 1984.

${ }^{93}$ Catherine Nash has noted how local history has been used to promote reconciliation. Like the Irish Club, communities in Northern Ireland have tried to focus on other ways of defining identity that offers an alternative to contentious nationalism. Catherine Nash, "Local Histories in Northern Ireland," History Workshop Journal 60 (Autumn, 2005): 45-47.

${ }^{94}$ Exhibit label, "What England Brought to Ireland,” The Irish Association of Manitoba, 06 January 2015.
} 
represent England in a series of pieces concerning the history of Ireland, it seems to have introduced an imbalance in some members' eyes.

Joe saw also saw the issue of the flag as essentially problematic and believed the Club's approach to the non-political element of the mandate was misguided.

J: You know, all the-the stuff over there. Um, and as-well, of course, initially you look at it and say, "Well, okay, yeah." We-we're acting as if we're living in Ireland. Uh, but we didn't realize that at the time, fully. So, this became engrained and as a consequence of that, uh, we didn't want to offend anybody so the Irish flag wasn't flown. Um, etcetera, etcetera. So, I remember, myself then years later at a meeting challenging that whole concept. As I said, like, non-political would mean not NDP, not Progressive Conservative...

K: It's like a Canadian non-political.

J: Exactly. And non-sectarian, well that's-that's okay, I mean, we understand that part. It's the same every-so you're-it's not going to confine yourselves to-to Catholics, or not going to rule out Jews, or Muslims, or whatever.

$\mathrm{K}$ : Yeah.

$\mathrm{J}$ : Um, and I think we just made it a rule that you had to be Irish, or your grandparents had to be Irish at the beginning.

$\mathrm{K}$ : Yeah, yeah.

$\mathrm{J}$ : Something of this nature. But I said, "This is nonsense. I mean, this nonpolitical. It doesn't mean what you guys think it means." And, um, and so I-I was at the stage of getting them to-yeah, to rescind that and to fly the Irish flag. But then I let them get away with it. ${ }^{95}$

Mary explained that the mandate was a well-meaning attempt to be more inclusive, particularly considering that other Irish associations, which have come and gone over the years, did not make the effort. She mentioned the Winnipeg Irish Association as an example. This was another association active in Winnipeg for a number of years that was primarily composed of Northern Irish Protestants who arrived in the 1950s. Mary explained that their facilities were located in the Thomas Scott Memorial Orange Hall - something which most Irish Catholics found distasteful. ${ }^{96}$ However, she

\footnotetext{
${ }^{95}$ Joe and Mary Campbell, interview by Kathryn Boschmann, Winnipeg, Manitoba, 17 July 2014.

${ }^{96}$ The founding members of the Manitoba Irish Association were not entirely at ease with the focus of the Winnipeg Irish Association which motivated them to establish their own organization. Jennifer Clary-
} 
felt that prohibiting the display of the Irish tricolour flag was the wrong way to go about inclusion. She explained, "they always viewed the Irish flag as though somehow it was subversive. I mean, the Irish flag hangs in the United Nations in New York!"'97 Joe and Mary's comments point to how political divisions were unintentionally brought into the Club through their effort to be non-political. In addition, the decisions of what activities are and are not acceptable within a non-political space and the enforcement of these boundaries becomes a political statement in itself.

For the Club to engage in activities that encourage pride in Irish heritage but to be so hesitant to display the Irish flag does seem, in some ways, contradictory. However, there are also those who value this policy and the sensitivity with which the Club treats the provenance of these cultural pieces. Brian explained that he believed rebel songs were becoming less common "because there's the recognition now that it's just protracting something that should have been pulled back on. If you want to look at them from the point of view-of a historical point of view, it's interesting to do. But, um, you've got to be very careful how you do it. Uh, as the Blarney Band, ${ }^{98}$ we never did rebel songs. The-the only rebel song we would do [was], 'The Rising of 1798.' Which is sufficiently far in the past. ${ }^{" 99}$ While historical distance might be stimulating a renewed popularity of Irish rebel

Lemon, “'We're not ethnic, we're Irish!': Oral Histories and the Discursive Construction of Immigrant Identity," Discourse Society 21, no. 1 (2010): 13.

${ }^{97}$ Joe and Mary Campbell, interview by Kathryn Boschmann, Winnipeg, Manitoba, 17 July 2014.

${ }^{98}$ The Blarney Band was a popular local Irish band which Brian played with for many years. "This night will be black and blue and green all over," Winnipeg Free Press, 23 February 1995. Brian also told a story of a flute player who would come to the Irish Club to join in the sessions and started talking about the political situation in the North. This man turned out to be an agent for the IRA who had done something similar in Vancouver and he was asked to leave the Club. Brian saw this as a sign of the Club's efforts to be "about forging links, not forging war." Brian Richardson, interview by Kathryn Boschmann, Winnipeg, Manitoba, 18 July 2014, Part 2.

${ }^{99}$ Ibid. Brian and the Blarney Band possibly felt this way not only because of the historical distance, but also because 1798 saw both a Catholic uprising in the southeast and a primarily Presbyterian rising in Ulster. This made the subject somewhat safer in a Northern Irish context. 
songs among some circles, Brian is clear that the provenance of these kinds of performances still holds a certain amount of power and needs to be treated with care in order not to continue bitter divisions.

Tom, in particular, highly values the non-political and non-sectarian aspects of the Club. He was raised Catholic in the Republic of Ireland, while his wife Heather, who is originally from Belfast, is Protestant. In addition, he has a close relationship with his inlaws, Eileen (who also participated in this project) and Ralph, an Anglican minister. Tom and Heather have considered moving back to Ireland but Tom explained that they chose against it, mostly because they did not want to have decide whether to send their sons to a Protestant or a Catholic school or what kind of church they would attend as a family. Tom and Heather are not the only Protestant-Catholic couple involved in the Club and Tom explained that gestures like not displaying the flag become very important for them while in that space. "[You] can't have it where a husband and wife go into the-the Club and there's one flag. Well, who's going to feel left out?"100

In another interview, Tom elaborated on the importance of leaving certain ideologies and memories at the door.

$\mathrm{T}$ : [There] has to be a recognition that we're not in Ireland. That we're here. That we can't bring the-all the bad stuff. We can bring all the great memories and the good memories and the land and the music and all that but we can't bring the blaming and the bloodshed and the, you know, "You're relative did this to my relative." In-in, you know, you can't bring those problems, those disasters. That history, you can't bring.

$\mathrm{K}$ : To, sort of, leave certain baggage at the door.

T: You have to leave it there. You have to leave it there. And so when, in the Irish Club, when somebody starts singing, you know, some heavy duty republican songs. Those republican songs are all about blaming. "It's their fault. It's the British Army's fault for this, that, and the other."

${ }^{100}$ Tom Naughten, interview by Kathryn Boschmann, Winnipeg, Manitoba, 10 June 2014, Part 2. 
K: Yeah.

T: Mmm, well, you know, you can't do that. And-and sometimes my father-inlaw or mother-in-law will say something that is-is very much their perspective on-of things. And I hear it an-and it rankles. And it goes, "Wait a minute, that's not how it happened." Or, "That's not how I understand it." Or, "That's not how I believe it happened." But those are really good moments to bite your tongue.

K: Right.

T: Um, and to-you know, I'm sure there are moments that I've spoken, not even thinking, that they have had to bite their tongue. And so I think we-we do the honor and do justice to one another, just by biting our tongue, and leaving it at the door. ${ }^{101}$

Like Joe and Mary, Tom talks about not being in Ireland and leaving the politics behind.

However, the stakes in this are higher for Tom since political and historical memory divisions exist within his family. There is a certain amount of self-editing because the relationship between family members is more important than differences of opinions concerning Ireland's past. For Tom, family is paramount to a symbol or a song. However, as Irish immigrants from a new context come to Winnipeg and look to the Irish Club for a sense of community and identity, the boundaries of the repertoire, which are already being pushed in some ways, may have to change to suit a new set of needs.

\subsection{Before cultural revival and multiculturalism: 1950s Irish immigrants}

Some who are a part of this story have a different view of the Irish past as well as the Club and the activities it supports. Pat and Catriona are siblings who migrated to Canada with their family in 1957 at the ages of 10 and 6, respectively. Their family owned a farm in Cootehill, County Cavan and their father invested in producing agricultural goods needed in Britain in the post-war period. Over the course of the late 1940s and early 1950s, the Labour government began to regulate various markets,

\footnotetext{
101 Tom Naughten, interview by Kathryn Boschmann, Winnipeg, Manitoba, 19 June 2014, Part 2.
} 
including agriculture, in ways that devastated farmers like Pat and Catriona's parents and this eventually motivated their decision to leave Ireland. ${ }^{102}$

These siblings describe a very different kind of relationship with Irish traditional performance than those from the Republic who left in the 1970s or later. Both explained that while they felt an appreciation for these activities and enjoyed seeing others pursue them, they had little or no desire to participate themselves. Pat has visited Ireland several times, often to connect with family, but explained that his children are probably more engaged with their Irishness than he is. ${ }^{103} \mathrm{He}$ told me "I must feel Irish because I am Irish. [...] I feel more Canadian, I guess." ${ }^{104}$ Catriona also described herself as being "very Canadian"105 but, of the two siblings, she expressed a stronger connection with their Irish heritage. She remembers being told about the kings of Ireland and St. Patrick

\footnotetext{
102 Patrick Gannon, interview by Kathryn Boschmann, Winnipeg, Manitoba, 25 June 2014. Also see Andy Bielenberg and Raymond Ryan, An Economic History of Ireland Since Independence (London and New York: Routledge, 2013), 16-19.

${ }^{103}$ Within this family, there appears to be a strong attraction to Irish heritage exhibited by the next generation. This seems to manifest primarily in family history research, travel, and tattoos. Pat explained how most of his children have traveled to Ireland and visited relatives there. He described this as a developing romantic attraction to the land and heritage. Catriona told me how her son tattooed the word "Irishman" across his back and her daughter got a tattoo with the name of their former dog along with a shamrock. While Catriona admitted that tattoos were not really her thing, she was amazed at how much her children seemed to connect with that aspect of their identity. Catriona Younger, interview by Kathryn Boschmann, Winnipeg, Manitoba, 09 July 2014; Patrick Gannon, interview by Kathryn Boschmann, Winnipeg, Manitoba, 25 June 2014. It could be argued that these choices are another kind of performative act. Like the actions of those interviewees who arrived in the 1970s, these are significant, embodied acts that demonstrate a connection to a certain group of people with a certain past. There has been some compelling research on memory and ethnic identity among second and third generation immigrants (Alexander Freund, "A Canadian Family Talks about Oma's Life in Nazi Germany: Three-Generational Interviews and Communicative Memory," in The Canadian Oral History Reader, eds. Kirstina R. Llewellyn, Alexander Freund, and Nolan Reilly (Montreal and Kingston: McGill-Queen's University Press, 2015), 159-179; Angela Cavender Wilson, "Grandmother to Granddaughter: Generations of Oral History in a Dakota Family," American Indian Quarterly 20, no. 1 (Winter, 1996): 7-13; Pamela Sugiman, "Memories of Internment: Narrating Japanese Canadian Women's Life Stories," The Canadian Journal of Sociology 29, no. 3 (Summer, 2004): 359-388). It would be worthwhile to further examine how these kinds of actions constitute a way of performing identity that runs parallel to the memories and experience of first generation immigrants. In this project, examining how first generation Irish Canadians understand the actions of their children, nieces, and nephews gives insight into communication rifts between different parts of the Irish Canadian community.

${ }^{104}$ Patrick Gannon, interview by Kathryn Boschmann, Winnipeg, Manitoba, 25 June 2014.

${ }^{105}$ Catriona Younger, interview by Kathryn Boschmann, Winnipeg, Manitoba, 09 July 2014.
} 
by her mother and her grandmother, included Irish harp music in her wedding to represent her heritage, and she sent her daughter to a week-long summer program at the Irish Club to gain an appreciation of the culture. At the same time, she does not consider all the particulars of the Irish past to be a part of her personal history. "Mine is more about the- the land and the people, um, that I come from, but not necessarily all the detail." For her, family history has a far greater draw, and she has pursued this through some genealogical research. ${ }^{106}$

Pat and Catriona's relationship with Irish history and traditional culture may be different from that of the Irish Canadians discussed early in this chapter, due in part to the young age at which they left Ireland (Catriona had not yet started school). However, it is also significant that the siblings left Ireland just as the 1950s cultural revival was gaining momentum. They were not exposed to traditional performances to the same degree as those who went through the Irish school system and immigrated to Canada as adults. They do not feel the same attraction to those activities as a way to express identity because they figured less in their experiences while in Ireland.

In addition, they came to Canada at a time when this country was encountering a steady stream of migrants - largely from Europe - following the devastation of World War II. Both government and local community programs sprang up across the country to deal with this influx. In general, the policy towards these newcomers was to encourage them to adopt an Anglo-Canadian middle-class model of life. In Winnipeg, programs

\footnotetext{
${ }^{106}$ Ibid. A significant part of the motivation to do this research was to find out medical history - something which Catriona has found her Irish relatives have been very hesitant to discuss. This research has led to some interesting discoveries concerning differences between the siblings' memories of family history, particularly concerning the deaths of Pat and Catriona's grandfathers. For more on this see: http://beingirishontheprairies.ca/\#!/then-the-reality-does-turn-out-to-be-a-different-kind-of-shade
} 
tended to be more pluralist but still maintained the goal of making immigrants "good Canadians" according to a certain set of principles. ${ }^{107}$

Irish Canadians who settled in Canada in the 1970s arrived either just before or after Prime Minister Pierre Trudeau introduced a policy of multiculturalism in 1971. The policy encouraged cultural organizations and supported aid programs directed by established immigrant communities for incoming newcomers. This shift in official policy characterized Canada as a country of ethnic diversity and led to the development of cultural festivals like Folklorama, which was discussed earlier. ${ }^{108}$ This environment of government-supported celebrations of the variety of ethnic communities in Winnipeg (and Canada more broadly) presented Canada as accommodating to newcomers. Policies and events such as these would play a role in how newly arrived immigrants might approach adjustment, shaping how much of their cultural life they feel able to participate in now that they are in a new context.

When Pat and Catriona arrived in Winnipeg, their family chose not to involve themselves in either of the two active Irish associations in the 1950s: the Sons of Ireland and the Irish Protestant Association. The Sons of Ireland publicized its mandate as nonpolitical and non-sectarian but there is little information available on how successful they were in meeting that goal. Both Catriona and Pat suspected their parents chose not to join the clubs because they appeared to be continuing the divisions in Ireland. ${ }^{109}$ When I asked if their family sought out an Irish community when they first moved to Winnipeg,

\footnotetext{
${ }^{107}$ Franca Iacovetta, Gatekeepers: Reshaping Immigrant Lives in Cold War Canada (Toronto: Between the Lines, 2006), 10-11; Loewen and Friesen, Immigrants in Prairie Cities, 92-97.

${ }^{108}$ Loewen and Friesen, Immigrants in Prairie Cities, 78, 92-97, 144-148.

109 “Bejabbers! Begorrah! Be Irish!” Winnipeg Free Press, 17 March 1954; “Winnipeg Irish honour St. Patrick at Banquet," Winnipeg Free Press, 19 March 1955; "Ireland's Sons Celebrate," Winnipeg Free Press, 18 March 1955; "Irish Protestants Keep St. Patrick in Memory," Winnipeg Free Press, 18 March 1955; "Irish Protestants' Ball Celebrates 'Seventeenth'," Winnipeg Free Press 18 March 1954.
} 
Pat explained that his mother had a group of Irish friends but otherwise there was no effort to make connections with other Irish Canadians. "Myself, I tended to more-and maybe [my parents] did to a degree too-not to want to get into a continuation of the, I don't know, more-more quasi-tribal kind of sense. I know, well, for myself anyways, it was-having no real desire to do that and maintain that part of-I guess, I felt negatively towards that part of a potential identity, sort of. With the two Irish Clubs here having split also along quasi-religious lines, didn't-didn't have a lot of- lot of appeal."110

Catriona expressed a similar perception of the Irish associations in Winnipeg (both past and present), but before I examine her comments more carefully, I want to suggest an explanation for this particular view of these Clubs. While Pat and Catriona described a variety of childhood memories and experiences of their lives in Ireland, most of what they talked about concerning Irish history in our interview was related to the Troubles and Irish struggles for independence. For example, one story that came up in both interviews concerned Pat, his brother Don, and some other Catholic school children who got into a scrape with the students attending the Protestant school. Both remembered that Don, who had broken his arm, used his cast to block the stones the children were throwing at each other. Pat explained that these conflicts were based in a deep sense of historical injustice.

P: I guess the kids reflective of what they learned in their respective environments tended to, um, be independent, antagonistic, basically, I guess, bigoted. I remember that Protestant kids seemed to be known as Proddy Dogs but I've been wracking my brain as to what the heck they-those kids called us. [...] The sense of having been, I don't know, treated unfairly by, sort of, previous generations I wouldn't say was drummed into me, but it was-it was osmosed.

\footnotetext{
${ }^{110}$ Patrick Gannon, interview by Kathryn Boschmann, Winnipeg, Manitoba, 25 June 2014. Pat's impression that the clubs were divided along sectarian lines may have been based on the presence of two clubs, one of which was Protestant.
} 
Um, the kind of family history where, at least on-on one kind of side it was the whole history of Battle of the Boyne, getting into the- the Irish rebellion in 19teens, with very strong anti-Catholic activity. And being on the part of the Catholic group, I guess we were feeling more of that unfairness and unfair treatment. Um, the British brought in a group called Black and Tans during the time of the-the Easter Rebellion, or before that, and these were, I guess, the worst kind of thugs, or whatever, from British prisons. And they brought them over to Ireland, or so we were told, to basically intimidate the local population. So that was, uh, that was a not- not, kind of, pleasant environment on-on most objective kinds of accounts. You'd have stories about, you know, so-and-so had taken over your-your great ancestor's house and was still in it and you'd be, you know, that was unfair. And, later on you'd think, "Well, gee, you know, so-and-so's been there now for hundreds of years."

$\mathrm{K}$ : Who knows how many generations.

P: Yeah, who knows how many and how displaced has-had that person been from somewhere else and so on. But...

$\mathrm{K}$ : Yeah.

P: ...when you're, uh, when you're in a compressed, kind of, environment, those kinds of- of pressures become-come more to the surface and they become more visceral, regrettably. ${ }^{111}$

While Catriona did not have the same kind of direct experience of those historical conflicts while she was living in Ireland, she told me that she was very upset when her father filed for Canadian citizenship for the family when she was about 10 or 11 years old. She had heard many stories of family members fighting for Irish independence, "And so it seemed to me that my dad was-was giving that up somehow. So I remember being really, really angry that he had-that he had made this choice for me when I didn't want it." 112 Despite her frustrations, her father was emphatic that they had to learn how to adjust and be Canadian (which could be seen as a sign of the effectiveness of the 1950s approach towards immigrants). Later, when she was 16, she had to go through the official process herself and explained, "Well, you know, when I was 16, I had to go do my own Canadian thing and I was quite horrified that I would have to do that. Because I knew I

\footnotetext{
111 Ibid.

112 Catriona Younger, interview by Kathryn Boschmann, Winnipeg, Manitoba, 09 July 2014. For more on this see: http://beingirishontheprairies.ca/\#!/because-all-of-the-stories-id-heard
} 
needed to-to have the Canadian citizenship. But I also knew that one of the things waswas, I think this was the sticking point for me, was pledging allegiance to the Queen. When all my ancestors had fought against having any allegiance to the Queen. So that was the really hard piece. [...] I don't personally hold the Queen responsible for what's happened but it- it was like a huge divide." ${ }^{113}$ It should be noted that this does not represent Catriona's present day feelings towards Canadian citizenship and the Irish past, but this story indicates the impression she had of Irish and family history in her teen years.

I would suggest that these memories and stories from childhood had a powerful effect on Pat and Catriona's perceptions of Irish history and shaped the way they interpreted the actions of Irish organizations. This helps to explain the different understandings they have of the provenance of the activities in the cultural repertoire and why they interpret certain responses from other members of the Irish community in the way that they do. For example, Pat and Catriona's niece, Margaret, organized a St. Patrick's Day parade in Winnipeg in 2012, which has now become an annual event. Both Pat and Catriona have participated in the parade and told me how pleased they were with the success it has enjoyed. However, Catriona expressed frustration with how the Irish Club and various dance groups initially responded to the event.

C: My niece, Margaret, decided 3 years ago she wanted to start the St. Patrick's Day parade. And so we-it was a beautiful spring. Like, it was a really nice spring. It was getting warmer, and warmer, and warmer. And so, um, I knew a bit about PR because I had done a lot of PR for volunteer organizations. So I got some PR out. And we had no idea how many people were coming. 300 hundred people came! But neither Irish Association was interested at all.

$\mathrm{K}$ : Really?

${ }^{113}$ Catriona Younger, interview by Kathryn Boschmann, Winnipeg, Manitoba, 09 July 2014. 
C: Yeah, they did not want to have anything to do with it. And when you notice at Folklorama, you have one Irish pavilion and then you have another one. We don't want any part of that. We're here. We're Irish. Yes, we fought for independence. Yes, we did this. But we're not here to carry on those divisions.

K: Divisions.

C: And I think that might be part of the reason why we didn't get involved in any of that. I mean, I sent Meghan to the Irish Association for a week long kind of camp to, you know, to learn a little bit about music and a little bit about dance and a little bit that. Just because she was looking for something to do and she had done dance, she had played soccer, she'd done all those things. But I thought this would give her a little bit of a connection. And it was great. But yeah, we're not associated, really, with any of those things. And I think that's part of-maybe that's part of it. That we don't really want the divisions to be more evident. That we're happy. You know, they were invited-they were invited, uh, you know, all of them were invited to participate and none of them chose to that year.

$\mathrm{K}$ : That's really interesting.

C: The dancers wouldn't either. Nobody would. Now, the next year the McConnell Dancers did come.

K: Okay.

C: And become part of it. It was freezing that year. They should have come the good year. ${ }^{114}$

There are several significant points of interest in this conversation. First of all, Catriona's point about the two Irish pavilions at Folklorama came up a few times in our interview. She has interpreted the multiple pavilions as based in political divisions within the community, and she is not alone in that evaluation of the situation. When I spoke to Joe and Mary, this point came up and they offered a different perspective. Mary told me that she was listening to the local $\mathrm{CBC}$ radio weekend program and heard a comedian bring up the issue as well as the fact that in 2014 there would be three Irish Pavilions instead of two (The Ireland-Irish Pavilion, Celtic-Ireland, and a pavilion for the United Kingdom which includes Northern Ireland). Mary exclaimed, "Oh, I was so mortified." 115 She and others have explained to me that these multiple pavilions are not based in Irish politics but dance school politics. Pavilions in Folklorama are a great way for Irish dance

${ }^{114}$ Ibid.

115 Joe and Mary Campbell, interview by Kathryn Boschmann, Winnipeg, Manitoba, 17 July 2014. 
schools to showcase their performers, advertise for the company, and bring in some funds. Shirley also believed this competition between the schools was inherent in the competitive nature of the dance world. ${ }^{116}$

The Irish Club has worked against multiple Irish pavilions in Folklorama in the past. The Club has organized a pavilion for the festival since 1972 and in 1976, the Folk Arts Council approved the addition of a pavilion put on by the Winnipeg Irish Association. Not only did the Club fear financial losses, they were also concerned that having two pavilions would imply to the public that they were reflecting the conflict in Ireland. It would appear that they were failing in their mandate to remain non-political and non-sectarian. ${ }^{117}$ Based on the responses of those from outside the Club, their fears appear to have been legitimate.

In her discussion of the St. Patrick's Day parade, Catriona also views the clubs' decision to not participate in the event as a sign of continuing political divisions. ${ }^{118}$ From the Club's perspective, however, the choice to not join in officially may have been partly motivated by their mandate. Parades have a long history of being political performances in Irish communities across the world. In her study of $19^{\text {th }}$ century St. Patrick's Day parades in Montreal and Toronto, Rosalyn Trigger explains that “St. Patrick's Day processions around the globe shared a range of similar goals, including affirmation of national or ethnic group solidarity, demonstration of the worthiness of the Irish as citizens, nationalist protests against British governance of their homeland, and expression

\footnotetext{
116 Shirley Foamete, interview by Kathryn Boschmann, Winnipeg, Manitoba, 17 October 2014. Also see: Joe and Mary Campbell, interview by Kathryn Boschmann, Winnipeg, Manitoba, 17 July 2014; Maureen Taggart, interview by Kathryn Boschmann, Winnipeg, Manitoba, 17 June 2014, Part 3. about the dance school politics in Folklorama.

117 "Irish group to take legal action if..." Winnipeg Free Press, 07 August 1976.

118 Catriona mentions two clubs. The Winnipeg Irish Association was still in operation at this point but, as mentioned earlier, it appears to have disbanded recently.
} 
of religious faith, as well as pure entertainment." 119 While in the 1950 s, St. Patrick's Day in Winnipeg appeared less connected with religion and was also celebrated by Protestant Irish groups, ${ }^{120}$ in Belfast these processions have been and are still strongly associated with political and sectarian schisms and often involve instances of violence. The display of flags in these parades carries particular weight in these spaces where nationhood is still a point of contention and nationality is deeply intertwined with religion. ${ }^{121}$

For Catriona and her family, these events are purely a celebration of their heritage and identity. In Ireland, she, Pat, and their brothers acquired a strong sense of the conflict through childhood escapades and family stories, but they were not exposed to or did not participate in the various ways these fraught politics were expressed through performance activities, like parades. While Catriona and her niece have put in a considerable amount of effort to make the procession a fun family event and be as welcoming as possible, the provenance remains.

Interestingly, in conversations dealing with Irish politics in Canada, several interviewees talk about "being here now" and not in Ireland. ${ }^{122}$ These statements indicate that there is a belief that a different space should mean a different kind of engagement (or disengagement) with the politics of the homeland. However, people are divided in their understandings of the provenance of performance pieces - including music, parades, and

\footnotetext{
${ }^{119}$ Rosalyn Trigger, “Irish Politics on Parade: The Clergy, National Societies, and St. Patrick's Day Processions in Nineteenth-century Montreal and Toronto," Histoire Sociale/Social History 37, no. 74 (November, 2004): 160. For more on Irish parades, see: Mike Cronin and Daryl Adair, The Wearing of the Green: A History of St. Patrick's Day (London and New York: Routledge, 2002); Michael Cottrell, "St. Patrick's Day Parades in Nineteenth-Century Toronto: A Study of Immigrant Adjustment and Elite Control," Histoire Sociale/Social History 29, no. 49 (1992).

120 “Ireland's Sons Celebrate," Winnipeg Free Press, 18 March 1955; "Irish Protestants Keep St. Patrick in Memory," Winnipeg Free Press, 18 March 1955; "Irish Protestants' Ball Celebrates 'Seventeenth'," Winnipeg Free Press 18 March 1954.

${ }^{121}$ Madeleine Leonard and Martina McKnight, "Traditions and Transitions: Teenagers' perceptions of parading in Belfast," Children's Geographies (2013): 7-8, 12-13.

122 See interviews with Catriona, Tom, and Joe.
} 
pavilions at Folklorama. The boundaries between political and non-political shift from person to person and lead to tensions concerning which activities and symbols are appropriate to include in the cultural repertoire of Irish Canadians in Winnipeg. These differences are based in historical contexts: those who came from Ireland in the 1970s as adults spent formative years in a political pressure cooker that shaped their understandings of what certain performative activities mean. Those interviewees who left as children in the migration wave of the 1950s had exposure to politics in the form of direct conflict (typically with other children) and through stories of family participation in independence movements. However, they left Ireland before they had much experience of other kinds of performance activities with deeply political associations. While both groups express a desire to be non-political and inclusive, their migration context and personal experience contributes to divided opinions on how best to achieve this goal.

\subsection{A troubled repertoire: The narratives of Northern Irish immigrants}

Differences concerning relationships with the provenance of traditional performances as well as what and how various individuals draw from the cultural repertoire are also apparent when examining the narratives of Greg and Eileen. Both were born and raised in Belfast, Northern Ireland and left for reasons connected to the Troubles. These two individuals expressed a significantly different relationship to traditional music and performance compared with the other interviewees.

Eileen is Protestant and left Northern Ireland as an adult with her husband Ralph and their two young daughters in 1975. She explained that she never regretted coming to Canada and felt that she was able to acclimatise to her new life relatively quickly. She 
partly attributed this to being immediately involved and included in the church community where her husband ministered. It was important for her to be able to integrate and, while she told me that she sees value in people being able to express their culture, she did not want to become isolated in an ethnic enclave (a concern Maureen also expressed). ${ }^{123}$ Greg, on the other hand, left with his family in 1985 when he was 15 years old and found adjustment to Canada extremely difficult. From his perspective, Belfast was (and, in many ways, still is) where he belonged and the move was not something he wanted for himself. He has never been able to consider Winnipeg home and has chosen not to acquire Canadian citizenship because he feels that it would distance him from his Irish identity and culture. ${ }^{124}$

While there are significant differences between Greg and Eileen's stories of Belfast and their migration narratives, their accounts also reveal some compelling similarities in the way that they relate to Irish music and performance activities. To begin with, while both expressed a connection with traditional music, neither have found it a particularly useful tool in expressing themselves as Irish. Much of this is due to colonial policies in Northern Ireland that policed participation in these activities due to their associations with nationalism and rebellion. ${ }^{125}$

Eileen explained how, as a child, she had little exposure to Irish music and her account of the situation alludes to several points of interest:

\footnotetext{
${ }^{123}$ Eileen Baxter, interview by Kathryn Boschmann, Winnipeg, Manitoba, 04 July 2014; Maureen Taggart, interview by Kathryn Boschmann, Winnipeg, Manitoba, 17 June 2014, Part 2.

${ }^{124}$ Greg McVicker, interview by Kathryn Boschmann, Winnipeg, Manitoba, 28 July 2014.

${ }^{125}$ Martin Stokes, "Introduction: Ethnicity, Identity and Music," in Ethnicity, Identity and Music: The Musical Construction of Place, ed., Martin Stokes (Oxford and New York: Berg Publishers, 1994), 8-10; Gillian McIntosh, The Force of Culture: Unionist Identities in Twentieth-Century Ireland (Cork: Cork University Press, 1999), 81.
} 
E: Um, when I was at school in Northern Ireland, Protestant schools weren't taught Irish dancing, they were taught Scottish dancing. Scottish country dancing.

$\mathrm{K}$ : Really?

E: Because Scots-Irish-there's a big contingent of Scots-Irish, which is what I am. My grand-my father's side. [...] And the-when you were taught the dancing at school it was Scottish dancing. Irish dancing was Roman Catholic. That was for the Roman Catholics. That wasn't for the Protestants. So, that was when I was growing up. I don't-it's not that way now obviously. I doubt even if they teach any kind of folk dancing in schools anymore.

$[\ldots]$

$\mathrm{K}$ : Um, what about the music then, that you played and sang? Was that also, sort of, a....

E: Most of our music would have been, um, well, it was all kinds of music. But if you want ethnic music, it probably was more Scottish flavoured than Irish music.

K: Right, yeah.

E: We didn't have-Irish music would have been more American Irish music. You know, like, When Irish Eyes are Smiling or The Londonderry Air or-those kinds of, um, songs. Traditional Irish music, we didn't-that was not played over the radio in Northern Ireland at the time that I was growing up.

$[\ldots]$

$\mathrm{K}$ : So, do you feel any sort of connection with that kind of music, then? Or is it just...

E: Oh, I do.

$\mathrm{K}$ : Yeah.

E: I'm very connected with it. I-I've always liked Celtic music. And I suppose Ialthough I'm saying we-we didn't hear it that much, I-I always would have recognized it when I did hear it. And I still have that very deep connection to Irish music. And when I played the harp, I played Irish music.

K: Wow. So when did you start playing the harp?

E: Oh, not until... 19-in the 1990s. [...] And I only played for a very short time. And then I-I suddenly just- when we moved from our home and... I don't know, I just never seemed to get back to it.[...] I keep saying I'm going to but I haven't. I haven't yet. And my fingers aren't as nimble as they once were. ${ }^{126}$

In this discussion, Eileen touches on the effects of political divisions on engagement with performance, including the depoliticized Irish music coming out of the diaspora (particularly North America). The accessibility of these Irish American songs in comparison to Irish traditional songs suggests that Irish songs produced in North America were considered safer. Tunes with a history were a powerful tool for the nationalist

\footnotetext{
${ }^{126}$ Eileen Baxter, interview by Kathryn Boschmann, Winnipeg, Manitoba, 04 July 2014.
} 
project and had the potential to become dangerous for a colonial power structure and were considered seditious.

Historian Gillian McIntosh argues that since unionism was based on the maintenance of the state, it was nearly always in a position of defence and cultural producers and gatekeepers (such as radio broadcasters, newspaper journalists and editors, and festival organizers) had to carefully manage what constituted a Northern Irish identity. For example, in the 1940s BBC Northern Ireland avoided as much as possible airing "more overtly 'Irish' broadcasts" or traditional music which was seen as congruent with nationalism. ${ }^{127}$

Eileen spoke of the kinds of separation she encountered when she lived in Belfast and explained that she never felt any particular animosity towards Catholics, but noted that there were few opportunities to get to know them.

You didn't go to school with them, you didn't go to church, you didn't go to the same places. In Southern Ireland, it was-it was different. So, it created a different kind of, um, culture. That's why I think there's-I mean, the Troubles, as they call them, in Northern Ireland, was because as the Roman Catholic population grew there was more tension between the Protestants and the Catholics because, obviously, they were not getting as many of their rights as they should have been. And, as I say, silly things like teaching us Scottish dancing. That was really... you know, we-we were Irish. But a lot of people in Northern Ireland don't think of themselves as Irish. They think of themselves as British. ${ }^{128}$

By encouraging separate spaces and cultural activities, unionist forces continued to distance Ulster-Scots from Irish identity which contributed to maintaining the established divisions between Protestant and Catholics in the North. Within this context, promoting

\footnotetext{
${ }^{127}$ McIntosh, The Force of Culture, 3, 80-82.

${ }^{128}$ Eileen Baxter, interview by Kathryn Boschmann, Winnipeg, Manitoba, 04 July 2014.
} 
Scottish culture in Protestant schools provided less threatening alternative folk ways than Irish traditional culture. ${ }^{129}$

While Eileen does talk about learning how to play the harp after moving to Canada and stresses the point that while she does feel a connection to Celtic music, she does not see these performances as a marker of identity in the same way as the interviewees from the Republic of Ireland, particularly those who came to Canada as adults.

$\mathrm{K}$ : And it's interesting too. One thing I've found is that a lot of people start to-I don't know, feel more Irish, but to get more involved with Irish traditional music and dance...

E: Yes.

K: ...after they-after they left.

E: Possibly, yeah.

$\mathrm{K}$ : And I wonder, is that-was that the same for you? That you felt...

E: No. No. I enjoy it but it doesn't- I don't- [...] Well, perhaps, obviously I-I'm more involved because our grandchildren and our son-in-law play music-Irish music. And I enjoy it when they're playing it. And I've gone to concerts and things. Um, but I wouldn't say that I've searched it out or anything like that, in a sense. And if they hadn't been interested, I'm not sure that I would have even had any particular interest. I mean, I enjoy hearing it. It's not that. And Folklorama, I've always gone to the Irish pavilion, obviously, and enjoyed it. But maybe that's because I was Protestant, rather than- and not being brought up in Southern Ireland. Probably that's part of it. ${ }^{130}$

Eileen's reasoning of why she did not feel an urge to seek out traditional Irish music points again to the significance of the context in Northern Ireland when she left and its role in shaping her relationship to Irish music in Canada. However, it is interesting to note how her suggestion about her background as Protestant in possibly contributing to

\footnotetext{
${ }^{129}$ Martin W. Dowling, "Confusing Culture and Politics: Ulster Scots Culture and Music," New Hibernia Review 11, no. 3 (Autumn, 2007): 51-80; Peter Robert Gardner, "Unionism, Loyalism, and the Ulster-Scots Ethnolinguistic 'Revival'," Studies in Ethnicity and Nationalism 15, no. 1 (2015): 4-25.

${ }^{130}$ Eileen Baxter, interview by Kathryn Boschmann, Winnipeg, Manitoba, 04 July 2014.
} 
this more distant relationship to Irish traditional performance is challenged when we compare her experience with Greg's story.

Greg was raised Roman Catholic and was five years old when Eileen left with her family in 1975 . He grew up during the height of the Troubles when participating in traditional Irish performances could be seen as a dangerous political act. ${ }^{131}$ Greg's mother was well aware of the implications of participating in these activities and he explained that she was careful to shield her children from politics as much as possible. He explained, "Because my mummy didn't want us to align with a green, white, and gold flag, an Irish tricolour. Didn't want us to align with the red, white and blue Union Jack. Didn't want us to identify with any of that. None of that was-it wasn't who we were. We were simply an Irish family growing up in the North of Ireland. We had no political ties. We were Irish Roman Catholic. We had no involvement in the Troubles. No interest in the Troubles."132

Greg stressed in our conversation that they could not express an Irish identity in Northern Ireland without serious consequences and explained how identity was policed on the streets by children in different neighbourhoods. For example, Protestant and Catholic children wandering into other neighbourhoods would be made to recite the Our Father, or the alphabet, or sing The Sash my Father Wore - a popular song about the victory of King William III in Ireland in 1690-1691. These were just a few of the tests that would give hints as to whether the visitors were Protestant or Catholic and whether

\footnotetext{
${ }^{131}$ May McCann, "Music and Politics in Ireland: The Specificity of the Folk Revival in Belfast," British Journal of Ethnomusicology 4 (1995): 63; Stokes, "Introduction," 8-10.

${ }^{132}$ Greg McVicker, interview by Kathryn Boschmann, Winnipeg, Manitoba, 28 July 2014.
} 
they should be welcomed or chased out of the neighbourhood. ${ }^{133}$ The kinds of childhood politics Greg describes were similar to those experienced by Pat and Catriona.

Like Eileen, Greg started learning how to play an Irish traditional instrument after coming to Canada (his instrument of choice was the bodhrán) but he also only plays it a little. He explained that he felt connected to Irish music but, at the same time, found it unfamiliar and difficult to identify with. When I asked him whether he and his family ever sought out an Irish community in Winnipeg, he explained that they had participated here and there with the Irish Club and that a few in his family had memberships.

However, he elaborated on this further:

G: So, we went to the Folklorama, connected with the Irish pavilion, you know, met up with some of the Irish community. You know, heard people in the neighbourhood who spoke with a Belfast accent, connected with them. But never really sought it out. Because we didn't have that back home either. We didn't go to any Irish Clubs back home. We'd go to our youth club, you know, at the local school and stuff like that, but never really went to any-any Irish Clubs to identify with that. Because that wasn't allowed. I didn't know my identity till I came over here and it took me a lot of years to find it. It wasn't allowed for us. So, you'd go in and you'd sit and have, like you know, a jar if you wanted. And you would watch the players playing the bodhran and the musical stuff like that but it wasn't home. It wasn't that sense of being-it was almost like, it was a group of Irish trying to recreate a sense of Ireland over here. But it wasn't the same. It just-it just didn't feel right for me. So...

$\mathrm{K}$ : And I guess especially you-if that wasn't a part of growing up too, then it wouldn't...

G: Yeah, it's not something...

$\mathrm{K}$ : ...it wouldn't feel like...

G: No, I mean, you sort it out and stuff like that, but I mean, it was just-it was just a small group of people and it was just, you had the Club there and you'd look around and you'd go "Oh, aye, this is great and all." And just like, it didn't last very long. [...] I went a couple of times. It wasn't for me. Because my dream was to go home. ${ }^{134}$

\footnotetext{
${ }^{133}$ Greg McVicker, interview by Kathryn Boschmann, Winnipeg, Manitoba, 28 July 2014.

${ }^{134}$ Ibid.
} 
The reasons why Greg and Eileen were not exposed to traditional Irish music while they were living in Belfast differ significantly and the contrasts in their memories of Ireland are based in the historic and political divisions between Protestants and Catholics. However, this comparison reveals that, although Greg and Eileen are from either side of the religious divide, they share more in common in the way they relate to Irish performance and history than with any of the other interviewees. In both cases, they were intentionally distanced from traditional performance because of its political connections and this shaped how they related to Irish traditional music after they were removed from the context of Northern Ireland.

This carries through into how they think about Ireland as a nation. Both explained that they thought of Ireland as a whole, or thought it should be a united country. However, they also pointed out that people from Northern and Southern Ireland are very different and have distinct views and memories of the Irish past. Greg noted the difference between the North and the Republic of Ireland, explaining, "They don't-they don't want the bitterness, they don't want the Troubles, they don't want all that sectarian rubbish that goes on. We never wanted it either. You know, we were never a part of it. [...] For such a wee, small place to be so bitter and to lose 3,700 lives during the years of the Troubles. And, you know, I think even the lilts in our brogues and stuff like that. Very, very different." ${ }^{\prime 135}$

Eileen echoed some of these observations, explaining to me:

I'm-and I feel that an all-Ireland should be an all-Ireland. And I don't think there'll be peace until there is. Till it's one country again. Having said that, people- Protestant-or Roman Catholics from Northern Ireland and Roman

${ }^{135}$ Ibid. 
Catholics from Southern Ireland are two different people. They're-they are very different in their outlook than what, um, as-as maybe Protestants are as well. Southern Ireland, it is a different culture. It's a-they are much more laid back. Um, I don't know whether they're any more tolerant but I think you'd find that there is a difference between Northern people as a whole and Southern people as a whole, whether they're Protestant or Roman Catholic. [...] I bet you they wouldn't think the same way. They'd probably have lots of difference of- of opinion. Here, you don't notice it because I think people say they're Irish, whether they're from North or South. ${ }^{136}$

I asked her what she thought accounted for the difference between those in the North of Ireland and those to the South, and she suggested that it was due to relatively common divides found in European countries between North and South, citing Spain as an example. It is not clear from her comment whether she is referring to all of the North of Ireland, including all nine of the counties of the province of Ulster or just the six counties under the jurisdiction of the United Kingdom. To include all of Ulster does not quite fit since the three counties that are part of the Republic of Ireland, while affected by the violence of the Troubles, have not experienced the same kinds of restrictions of culture. Donegal, for example, is the most northern county of the island and, while it differs in certain ways from the rest of the Republic, there is a strong presence of Irish traditional culture in terms of language and performance in this area. ${ }^{137}$ I would argue that these differences are largely based in the historic political divisions and the effects of colonialism in Northern Ireland.

There are certainly striking similarities in Eileen and Greg's relationship with Irish traditional music and performance but they differ significantly in their desire to identify with a sense of Irishness. As was noted earlier, Eileen enjoys traditional performances but is primarily motivated to attend Irish musical events because of the

\footnotetext{
${ }^{136}$ Eileen Baxter, interview by Kathryn Boschmann, Winnipeg, Manitoba, 04 July 2014.

${ }^{137}$ William J. Smyth, "Culture, Identity and Tradition: Changing Definitions of Irishness," in In Search of Ireland: A Cultural Geography, ed. Brian Graham (London and New York: Routledge, 1997), 35.
} 
interest Tom, Heather, and their sons (her grandchildren) take in the activity. Otherwise, she has not felt a great pull to finding a performance avenue that would connect her to her Irish identity. Toward the end of our interview, Eileen paused and told me, "I guess I haven't really done a great deal in Ireland-or in Canada of any type of Irishness except be myself." 138 I would suggest that this is partly due to Eileen's context in Northern Ireland and growing up in an environment that was intentionally distanced from Irish traditional culture. Traditional Irish activity was not part of her life in Ireland and so there was not the same need to connect with it in Manitoba to feel Irish. In addition, Eileen feels at home and content in Winnipeg, unlike Greg who described feeling out of place in the prairies.

While Eileen expressed a comfort at just being Irish without searching for something that would help reinforce that aspect of herself, Greg described a search for a sense of identity and Irishness that lasted most of his youth and young adulthood - an important theme of his book, Through the Eyes of a Belfast Child: Life. Personal Reflections. Poems. The most common avenue available to achieve a sense of being Irish in Winnipeg was (and still is) through traditional performance - an approach that does not entirely resonate with Greg. He explained, "I mean, like, oh, I'm from Northern Ireland, I'm from Belfast. Aye, and I'm Irish. But really, what did that mean? Because again, it wasn't allowed for back home. We weren't allowed a sense of identity. [...] But to try and find a sense of Irish culture or Irish identity, did that mean, you know, listening to Celtic music or you did Irish dance? We never had any of that growing up."139

\footnotetext{
138 Eileen Baxter, interview by Kathryn Boschmann, Winnipeg, Manitoba, 04 July 2014.

${ }^{139}$ Greg McVicker, interview by Kathryn Boschmann, Winnipeg, Manitoba, 28 July 2014.
} 
Identifying with Irish traditional culture has been a lifelong search and his Irishness is instead based on his deep connection to Belfast and the surrounding area.

The Irish language was also something Greg feels was robbed from him as a child. The language was not recognized by the British government and he did not begin to learn it until he was about twelve years old. His first year of lessons was traumatic as the Christian Brothers priest who was teaching his class sexually assaulted a number of his classmates and Greg remembers having to be cautious to avoid becoming another victim. He has written about this experience in his book in which he explains that, although he had other Gaelic teachers who were not predatory, as well as opportunities to go to the Gaeltacht to participate in Irish lessons, the traumatic experience of his first Gaelic teacher had created deeply negative associations with language itself. ${ }^{140}$ While he knows a few phrases in Irish, including how to bless himself, these experiences have continued to make him uncomfortable with the language which would have, in other circumstances, potentially served as an avenue to express his identity as Irish.

That being said, Greg has found a number of ways to ground his sense of Irishness in Canada. While he has felt somewhat disconnected from Irish traditional music, he has developed a love for Irish rock and metal over the years. In our conversation, he explained how the Northern Irish band Mama's Boys has been a favorite since his teen years and he appreciates the ways in which they integrated their Irish roots into their music. ${ }^{141}$ Music scholars have pointed out that, while traditional music had

\footnotetext{
${ }^{140}$ Greg McVicker, Through the Eyes of a Belfast Child: Life. Personal Reflections. Poems. (Victoria, BC: FriesenPress, 2014), 57-62. The Gaeltacht is an Irish term which refers to regions where there is a high percentage of Irish language speakers. These are located primarily along the west coast of the island. Nuala C. Johnson, "Making Space: Gaeltacht Policy and the Politics of Identity," in In Search of Ireland: A Cultural Geography, ed. Brian Graham (London and New York: Routledge, 1997), 174.

${ }^{141}$ Greg McVicker, interview by Kathryn Boschmann, Winnipeg, Manitoba, 28 July 2014.
} 
become politically fraught in the North, genres like punk and rock were somewhat more neutral territory. This enabled some musicians to criticize the conflict and Northern Irish politics at a greater distance, in comparison to traditional genres which have a provenance deeply connected to this political history. ${ }^{142}$

Writing has also played a significant role in the development of Greg's sense of Irish identity, and he described the process as a kind of exorcism - a way to express and locate his identity after leaving Ireland. ${ }^{143} \mathrm{He}$ sees storytelling as part of the Irish make up, referencing how asking for directions in Ireland tends to end up as a story session $-\mathrm{a}$ point that came up in several interviews. ${ }^{144} \mathrm{He}$ has written a series of children's books called The Adventures of Silly Billy which are based on his childhood experiences in Belfast, and in 2014 he published Through the Eyes of a Belfast Child. The book includes short stories and poems concerning the joys and challenges of his youth, the difficulties of migration, finding identity in Canada, and anecdotes about friends and family (often in reflections he dedicates to the people he writes about to express thanks for their influence in his life). In this publication, he attempted to capture a sense of orality in his writing to reference traditional ways of telling stories and the Irish "Gift of the Gab." ${ }^{145} \mathrm{His}$ description of the process of writing demonstrates the way it has allowed him to claim his identity and make meaning out of his experiences:

\footnotetext{
${ }^{142}$ Michael J. K. Walsh, "Mama's Boys, Celtus, and the Troubles in Northern Ireland," Rock Music Studies 2, no. 1 (2015): 46-60; Martin McLoone, "Punk Music in Northern Ireland: The Political Power of 'What Might Have Been'," Irish Studies Review 12, no. 1 (2004): 29-38; Bill Rolston, "This is not a rebel song': The Irish Conflict and Popular Music," Race \& Class 42, no. 3 (2001): 49-67.

${ }^{143}$ Greg McVicker, interview by Kathryn Boschmann, Winnipeg, Manitoba, 28 July 2014. Interestingly, Brian also used this term to describe his experiences of writing about his personal history. Brian Richardson, interview by Kathryn Boschmann, Winnipeg, Manitoba, 18 July 2014, Part 1.

${ }^{144}$ Shirley Foamete, interview by Kathryn Boschmann, Winnipeg, Manitoba, 17 October 2014.

${ }^{145}$ McVicker, Through the Eyes of a Belfast Child, vii.
} 
What I found was writing actually-writing this book has given me a chance to look back and, kind of, find that lost soul who has been trying to find his world view and a sense of identity all these years. And where do I fit in, where do I belong, who am I? But what I realized by doing that, I wasn't just telling my story. I was telling the story of other people as well. As you'll see when you're reading, you'll see that I talk about people who have come into my life. And how they have left a footprint on my soul. And helped define my worldview. [...] So, writing's a... writing has been, um... has been healing. Has been reflective. ${ }^{146}$

I would argue that, along with Irish rock and writing, Greg's Belfast accent has also played a significant role in distinguishing himself as Irish. Accents came up often in many of my interviews and are an important part of Irish culture. Indeed, while I was traveling in Ireland, I became very aware of my own way of speaking and knew that as soon as I opened my mouth, the people listening would be identifying me (most likely as an American). Sharon Slater, told me that accents were an important part of whether locals think of members of the diaspora as Irish or not. She explained that if first generation Irish immigrants still have their accents, they are still considered to be Irish. If they have lost their accent over time, the locals tend to view them as not fully Irish. ${ }^{147}$

Accents seem to have played a particularly significant role in Greg's experience and act as another kind of repertoire. Throughout our interview, Greg returned to the subject of his Belfast brogue - how it differed from the way Canadians spoke, the difficulties people had understanding him, and how enjoyable it was to hear others speak with the same accent. He told me several stories of Canadians who were unable to understand him when he said words like "cow" or "snout" or not knowing how to respond when he said "aye." 148 One story, which featured both in our interview and in his

\footnotetext{
${ }^{146}$ Greg McVicker, interview by Kathryn Boschmann, Winnipeg, Manitoba, 28 July 2014.

147 Sharon Slater, interview by Kathryn Boschmann, Limerick, Ireland, 17 August 2014.

${ }^{148}$ Oral historians Marilyn Barber and Murray Watson have also noted the significance of accents in their interviews with English immigrants in Canada. While English newcomers in the post-war period were not visually identifiable, their accents would instantly set them apart. Like Greg, these migrants often discussed
} 
book, effectively illustrates the connection Greg has drawn between the way he speaks and his Irish identity. He recalled being told several times to change his accent while growing up in Canada. It was frustrating for him to leave a country where he was not allowed to develop a sense of Irish identity and come to a supposedly multicultural Canada where he was told, "Speak English or go home." He explained, "I was a stranger in two worlds." ${ }^{149}$ In 1992, after seven years in Canada, he returned to Ireland for the first time following the passing of his grandmother. He had chosen to do a reading at her funeral and afterwards friends and relatives commented on how half had been spoken in a Belfast brogue and the rest with a Canadian accent. They told Greg, "You're a man of two countries and one without an identity. You need to get yourself sorted, mucker." ${ }^{150}$ In his book, Greg writes that this was a turning point for him, "I'd had enough. No longer was I going to take on an identity to please everyone else." ${ }^{151}$ This comment clearly demonstrates the strong association he has established between his identity and his Belfast accent.

This is significant, too, because Greg's accent not only identifies him as Irish but also as from Belfast. He explained to me that while he can enjoy himself and feel comfortable anywhere in Ireland, "Home is Belfast."152 Those familiar with the repertoire of Irish accents would be able to pick up where he was from relatively easily. Those who would not be able to distinguish where his accent is from, would at least be able to tell he

\footnotetext{
difficulties in communicating with other Canadians. Barber and Murray explain that some found this a profoundly uncomfortable experience and several took efforts to lose their accents. Greg, on the other hand, makes a concerted effort to hang onto his accent as a marker of identity. Marilyn Barber and Murray Watson, Invisible Immigrants: The English in Canada since 1945 (Winnipeg, MB: University of Manitoba Press, 2015), 3, 101-105.

${ }^{149}$ Greg McVicker, interview by Kathryn Boschmann, Winnipeg, Manitoba, 28 July 2014.

${ }^{150}$ Greg McVicker, interview by Kathryn Boschmann, Winnipeg, Manitoba, 28 July 2014.

${ }^{151}$ McVicker, Through the Eyes of a Belfast Child, 27.

${ }^{152}$ Greg McVicker, interview by Kathryn Boschmann, Winnipeg, Manitoba, 28 July 2014.
} 
is not originally from Canada. Greg's Belfast brogue does a similar kind of work as the repertoire of traditional music and performance in the lives of Irish Canadians who originated from the Republic of Ireland. It provides a way for Greg to distinguish himself from other Canadians and connect with a particular place, people, and history.

\subsection{Conclusion}

I have argued in this chapter that stories of traditional performance told by my interviewees revealed the deep connections these cultural repertoires have with the Irish past. Traditional performances were infused with particular meanings and associations when they were enlisted in independence movements and state programs to promote national pride. This provenance would have a significant effect on how my interviewees interacted with these performances in the new context of Canada. Those who left the Republic as adults in the 1970s had experienced cultural revivals which reinforced traditional performance as a marker of Irish identity. In addition, the Canadian national policies of multiculturalism introduced in this period encouraged these kinds of ethnic activities. These individuals could then draw upon this repertoire to contribute to their sense of Irishness while living in Canada. Conversations about these performances were often connected to ideas of authenticity, but they were also tied to the recognition that these cultural activities serve an emotional purpose. The ability of certain traditional performances, particularly music, to provide a kind of ready-made community with a shared repertoire brought significant emotional comfort to many interviewees. However, the desire to avoid the divisive politics of the homeland led to concerns about the provenances of these cultural activities. Tensions arose within the community over which 
performances should be included in the repertoire now that participants were in a new context. While some continued to press for the exclusion of the more politically charged cultural activities in the interest of inclusiveness, others (particularly the newer generation with greater historical distance from the Troubles) have begun to critique these restrictions.

Those who arrived in Canada in the 1950s as children had a very different understanding of politics in the cultural repertoire. They had personal experience of the conflict as children as well as family stories about rebellion and resistance against the British. However, their experiences of cultural performances and their political associations were limited in both Ireland and Canada due, in a large part, to state policies. This led to considerably different relationships with the repertoire and alternate understandings of the meaning of traditional activities.

Interviewees who left Northern Ireland in the context of the Troubles had another understanding of the provenances acquired by traditional performances. Efforts were made by individuals, communities, and officials to create distance between inhabitants of Northern Ireland and traditional performance. The association between nationalism and Irish cultural activities made them particularly charged in this unstable atmosphere. These interviewees then had little exposure to these activities during their lives in Belfast and did not find them particularly effective as ways to reinforce their sense of Irish identity. While Eileen did not express a great desire to create a sense of Irishness in Canada, Greg felt otherwise. He found other ways to express his identity as Irish and a child of Belfast through his writing and his brogue. 
Accents, music sessions, festivals, parades, and related activities have been shown here to have deep roots in the Irish past. While many interviewees share the sentiment that the contentious politics of Ireland should be left behind ("We're here now"), this has proven to be easier said than done. These traditional performances cannot be separated from their provenance, especially when that colonial history maintains a prominent place in the memories of community members. In order for the Irish Canadian community to make their collective repertoire as inclusive as possible, they negotiate both personal and historical memories: to try to forget or set aside what is divisive and keep what builds communities. However, agreeing where this boundary between memory and forgetting, and political and non-political, should fall is difficult and generates tensions. The variety of migration contexts and personal experiences result in distinct relationships with the traditional performances and differing ideas of what activities belong in the repertoire and which are better left at the door.

The next chapter will examine how, like the repertoires of cultural performance, spatial and environmental repertoires are deeply connected to memory, and the narratives of embodied experience reveal ways in which these Irish migrants have located belonging. 


\section{Chapter Two \\ "The rest is sky": \\ Landscape, weather, and identity in Ireland and Manitoba}

When I visited the small tourist village of Doolin in County Clare, I happened to stop by a little candy shop. While perusing the various sweets, I struck up a conversation with the owner who was curious about where I was from. Our conversation quickly turned to the beauty of the village and surrounding area and she began to speak of her family's love for the place. She told me how her father would watch every sunset over the ocean as if it was his first and how her niece spoke of loving the way the mountain laid back over the land. This conversation brought me back to the many times my interviewees had talked about their experiences within the landscapes of Ireland and Manitoba in similar emotional, and often poetic, terms.

These moments in our conversations revealed the significance of embodied experiences of the land and its weather. Anthropologist Tim Ingold argues that we are participants in the landscapes we inhabit: we soak in the sunshine, feel the wind, and tread the ground. Drawing from archaeologist Christopher Tilley, Ingold explains that landscapes are not objective constants, but are in ever shifting relationships with their inhabitants. "Landscape takes on meanings and appearances in relation to people, and people develop skills, knowledge, and identities in relation to the landscapes in which

they find themselves." Land and weather play a principal role in shaping our impressions and experiences of a space or place. The physical elements of the places we call home ground us in a sense of identity and connect us to those who lived there in the past.

\footnotetext{
${ }^{1}$ Tim Ingold, Being Alive: Essays on Movements, Knowledge and Description (London and New York: Routledge, 2011), 129.
} 
Migration often involves adjustment to a significantly different environment and many migrants experience a feeling of being dislocated.

In this chapter, I will examine how embodied experiences of Canadian (particularly Manitoban) and Irish environments featured in the narratives related by my interviewees and how these stories worked to explain connections to the past, convey emotions associated with their migration, and express their former and current senses of identity. Drawing on Taylor's concept of repertoire, I argue that these stories concerning space can be powerful narrative tools, because they are based in a shared experience of landscape and climate. These common experiences constitute another kind of repertoire, where repeated embodied acts (for example, running from a brief shower in Ireland or bundling up to face a Manitoban winter) take on significance and are translated into stories that transfer emotional meaning in conversations with others. ${ }^{2}$ In what follows, I will outline the historiographies of landscape and weather, the theoretical framework from which I will draw for my analysis, and draw attention to the politics of memory and place. I will then analyse interviewees' narratives about the environments of Canada and Ireland: their relationship with the homeland, adjustment to the prairies, and feelings of belonging.

\footnotetext{
${ }^{2}$ Diana Taylor, The Archive and the Repertoire: Performing Cultural Memory in the Americas (Durham, NC: Duke University Press, 2003), 2-3, 16-21. Emotion is an important theme that weaves through this chapter. There is a rich scholarship on this subject. See: Jan Plamper, The History of Emotions: An Introduction (Oxford: Oxford University Press, 2015); William M. Reddy, The Navigation of Feeling: A Framework for the History of Emotions (Cambridge: Cambridge University Press, 2001); Barbara H. Rosenwein, "Worrying about Emotions in History," The American Historical Review 107, no. 3 (June 2002): 821-845; Peter N. Stearns and Carol Z. Stearns, "Emotionology: Clarifying the History of Emotions and Emotional Standards," The American Historical Review 90, no. 4 (October 1985): 813-836. For oral histories that deal with emotions see: Kathleen deMarrais and Kit Tisdale, "What Happens When Researchers Inquire Into Difficult Emotions?: Reflections on Studying Women's Anger Through Qualitative Interview," Educational Psychologist 37, no. 2 (2002): 115-123; Sean Field, "Beyond 'Healing': Trauma, Oral History and Regeneration," Oral History 34, no. 1 (Spring 2006): 31-42; Pamela Sugiman, "'These Feelings that Fill my Heart': Japanese Canadian Women's Memories of Internment," Oral History 34, no. 2 (Autumn 2006): 69-84.
} 


\subsection{Bodies and environments: Theoretical framework}

The connection between landscape, emotion, memory, and history has increasingly become a topic of discussion among academics in several disciplines, as noted by geographers Joyce Davidson and Christine Mulligan. They trace the roots of the rising interest in emotion and geography to the developments in research concerning embodiment and landscape, pointing to the link between our bodily experiences and our emotions. ${ }^{3}$ Our embodied experiences constitute a kind of knowledge that is physically sensed, while emotions are felt responses to these experiences.

Joy Parr's scholarship on embodied histories is a compelling example of the kind of serious treatment these topics have been given within the discipline of history. Her book Sensing Changes: Technologies, Environments, and the Everyday, 1953-2003 (2010) examines Canadian communities that have been affected by megaprojects that have drastically changed their environments. In this study, Parr describes bodies as "the instruments through which we become aware of the world beyond our skin, the archives in which we store that knowledge and the laboratories in which we retool our senses and practices to changing circumstances." She argues that we should attend to our "fleshly" perceptions which take on meaning with repeated experience. ${ }^{5}$ For example, we learn that a hot humid day that is interrupted by a cold wind often means a storm will follow. We know this because we have experienced that series of events repeatedly and have come to understand its meaning.

\footnotetext{
${ }^{3}$ Joyce Davidson and Christine Milligan, "Embodying Emotion Sensing Space: Introducing emotional geographies," Social \& Cultural Geography 5, no. 4 (December, 2004): 523-524.

${ }^{4}$ Joy Parr, Sensing Changes: Technologies, Environments and the Everyday (Vancouver: UBC Press, 2010), 1.

${ }^{5}$ Ibid., 1-8.
} 
Our environments change over time and have a history, and so do our bodily experiences. Environmental historian Linda Nash has studied the relationship between bodies, health, and the environment in the Californian Central Valley and the ways in which inhabitants' experiences of their bodies have transformed over time. She explains that, while we typically associate knowledge with our minds, there is a kind of knowledge that is obtained through living in material environments - an embodied knowledge. ${ }^{6}$ This kind of knowledge plays an important role in how we understand our individual and communal identity and the world around us. As Parr notes, "Daily we learn through our senses; we act through routines and react by reflexes so practiced they seem inborn; our time and place inscribe our bodies with habits that, in time, elude conscious awareness." J Jarring changes to our environment, then, can have a significant effect on our narratives about ourselves, and our everyday actions adjust in order to adapt and make sense of that change. ${ }^{8}$

I argue that as the body acquires knowledge and adapts to new spaces, we acquire a kind of environmental repertoire - the kind of bodily archive that Parr describes. This kind of knowledge manifests itself in many ways: how we move, how we dress, what we eat, how we socialize, our livelihoods, and our emotions. For example, in winter, inhabitants of Winnipeg know that we have to wear several layers, to spray our shoes to protect them from the salt spread throughout the city, and that it is not safe to walk on ice

\footnotetext{
${ }^{6}$ Linda Nash, Inescapable Ecologies: A History of Environment, Disease, and Knowledge (Berkeley and Los Angeles: University of California Press, 2006), 9-11.

${ }^{7}$ Joy Parr, "Notes for a More Sensuous History of Twentieth-Century Canada: The Timely, the Tacit and the Material Body," The Canadian Historical Review 82, no. 4 (December 2001): 720.

${ }^{8}$ Parr, Sensing Changes, 1-4, 18-22. Conevery Valencius also examines how immigrant settlers experienced and adjusted to a drastically different environment in her study of health and bodies in the $19^{\text {th }}$ century. Conevery Valencius, The Health of a Country: How American Settlers Understood Themselves and Their Land (New York: Basic Books, 2002).
} 
until it has reached a certain thickness. Shirley remembered a winter in Ireland when there had been some flooding and a drop in temperature so that everything froze. Many were not aware that the new ice was unsafe and some people were killed trying to walk or sled over it. ${ }^{9}$ Knowledge of when to trust ice to carry your weight was not a part of their environmental repertoire because they had so little past experience of it.

This knowledge becomes part of a shared environmental repertoire which not only affects how we act, but also shapes how we identify ourselves as members of a particular geographic community and convey that identity to others. In my personal experience, when I have traveled outside of Canada, my conversations with people from other countries often turns to a comparison of their respective climates to Canadian winters and a discussion about how big Canada is, despite its relatively small population. In these conversations, geography and climate play a significant role both in how I and others imagine Canada.

Considering embodied experiences seriously means that everyday activities take on new implications and deserve greater attention. As the editors of the volume Emotion, Place and Culture (2009) argue, "doing emotional geographies might transform the assumptions and actions embodied in such ordinary practices of walking, driving, reading and living in the wake of traumatic losses and displacements." ${ }^{10}$ In my interviewees' narratives, these commonplace activities and moments, particularly driving or walking, take on significant meaning. The manner in which these activities featured in their stories

\footnotetext{
${ }^{9}$ Shirley Foamete, interview by Kathryn Boschmann, Winnipeg, Manitoba, 26 June 2014, Part 1.

${ }^{10}$ Mick Smith et al., "Introduction: Geography and Emotion - Emerging Constellations," in Emotion Place and Culture, eds. Mick Smith et al. (Surrey: Ashgate Publishing Ltd., 2009), 13.
} 
communicated emotional experiences concerning their migration, including the feelings of dislocation and isolation shared by many immigrants.

Tilley takes a phenomenological approach to landscape and argues that space should be seen as a medium for action which cannot be separated from the activities that happen within its confines. Space provides the context for individual and societal experiences and repeated encounters with a certain geography and climate shape the structures around lives and identities. Tilley explains, "Daily passages through the landscape become biographic encounters for individuals, recalling traces of past activities and previous events and the reading of signs - a split log here, a marker stone there. All locales and landscapes are therefore embedded in the social and individual times of memory." 11 In addition, encounters with new spaces are understood in relation to other, familiar landscapes - creating a kind of spatial repertoire. We compare the new places to ones we have encountered before, locating difference and similarities, in an effort to understand how we should move through them and respond to their characteristics. ${ }^{12}$

While there has been a considerable amount of work done concerning these subjects of landscape, embodiment, and identity, there is comparatively little on the role

\footnotetext{
${ }^{11}$ Christopher Tilley, Phenomenology of Landscape: Places, Paths and Monuments (Oxford and Providence: Berg Publishers, 1994), 27. This quote from Tilley captures a sense of moving through space in the process of forming memory. Movement is an important aspect of Ingold's concepts of place making and he suggests, "if perception is thus a function of movement, then what we perceive must, at least in part, depend on how we move." Ingold, Being Alive, 46. For more on Ingold's ideas about place and movement, see http://beingirishontheprairies.ca/\#!/itll-always-be-a-part-of-my-heart

12 Tilley, Phenomenology of Landscape, 10-15, 27. Simon Schama and Claire Elizabeth Campbell both discuss how landscape and our subjective perceptions of it are at once both separate and deeply intertwined. Schama explains that while ecosystems proceed independently from human involvement, they have also been greatly affected by human influences and cultures. In additions, human cultures are profoundly shaped by their environments and engage in both locating and venerating wilderness. Simon Schama, Landscape and Memory (New York: Vintage Books, 1995), 7-16. Campbell echoes this in her study of Georgian Bay and emphasize the importance of studying the local. "Pinning history to a particular place emphasizes the influence the physical environment has had over human history." Claire Elizabeth Campbell, Shaped by the West Wind: Nature and History in Georgian Bay (Vancouver: UBC Press, 2005), 17.
} 
of weather in shaping our experience of a place. There is a growing interest in long-term climate patterns within the field of environmental history, largely due to the pressing concerns of climate change. This literature, however, does not typically examine individual and group embodied experiences of weather (short-term weather events) and their role in identity narratives. Environmental scientist Ben Orlove and anthropologist Sarah Strauss have also worked to address this issue and compiled an edited volume entitled Weather, Climate, Culture (2003). In their introduction they argue that "the cognitive and symbolic aspects of weather and climate deserve as much attention as the responses to specific weather events or conditions, since these two are ultimately inseparable."13 The felt experiences of weather and different climates are central to shaping our impression of a place.

Environmental historian Teresa Devor has also drawn attention to weather through her work on British migrants and American Loyalists living in the Atlantic Provinces. She points to a process of interacting with weather that mirrors Tilley's discussion of landscape and argues that there is a continual process of "integrating traditional ecological knowledge from emigrant's [sic] former home places, with experiential knowledge developed through observations of the effects of weather on the land and waterscapes of their new homes."14 Like landscape, differences in weather and climate are also incorporated in our environmental repertoire as we adjust to a new place.

\footnotetext{
${ }^{13}$ Sarah Strauss and Benjamin S. Orlove, "Up in the Air: The Anthropology of Weather and Climate," in Weather, Climate, Culture, eds. Sarah Strauss and Benjamin S. Orlove (Oxford and New York: Berg, 2003), 6 .

14 Teresa Devor, “'Living Weather' and Survival: Learning Local Weather Ecology in the Maritimes and Newfoundland, 1780-1920," accessed 4 August 2015, http://www.historicalclimatology.com/teresa-devorliving-weather.html.
} 
Like the scholars above, Ingold challenges the neglect of weather in discussions of landscape. He insists that "to inhabit the open is to dwell within a weather-world in which every being is destined to combine wind, rain, sunshine and earth in the continuation of its own existence." ${ }^{\prime 15} \mathrm{We}$ cannot separate our experience of a landscape from our experience of its weather. As Ingold argues, earth and sky are bound together as they shape and are shaped by one another. ${ }^{16}$ The human processes of finding meaning in the environments they inhabit are then deeply connected to their experience of its elements. My interviewees' narratives of place reflect this relationship.

Since spaces are given meaning through human relationships and perceptions, they also become what Tilley describes as "value-laden rather than value-free and political rather than neutral."17 Like Tilley, Brian Graham and the other authors featured in his edited volume, In Search of Ireland: A Cultural Geography (2003), recognize how conceptualizations of place are drawn into political discourses and, in some cases, have been used to continue divisions within Ireland. Graham explains how nationalism is based on ideas around possession and control of territory and these spaces become symbols of a shared past and identity. Images and references to the spaces of historical action and ownership are often used as tools to lend authority to nationalist claims. ${ }^{18}$

As an example this process, Graham points to Ireland's west coast counties, particularly the Gaeltacht regions, which were key elements of nationalism in the nineteenth and twentieth centuries, and which continue to be central to the ways in which

\footnotetext{
${ }^{15}$ Ingold, Being Alive, 115.

${ }^{16}$ Ibid., 121-123

17 Tilley, Phenomenology of Landscape, 20.

${ }^{18}$ Brian Graham, "Ireland and Irishness: Place, culture and identity," in In Search of Ireland: A Cultural

Geography, ed. Brian Graham (London and New York: Routledge, 1997), 4-5.
} 
Ireland is imagined. Its idealized image and inhabitants became engrained in the nationalist narrative as emblems of true Irishness, largely untouched by British colonialism. Graham argues the power of this symbolic landscape and the rural people within it only began to weaken in the 1960s when "it bore no more than a 'tenuous relation to reality' in the South, while it had never accommodated the Protestant, industrialised counties of northeast Ireland." ${ }^{19}$ Nuala C. Johnson explains that the west continues to be prominent in tourism advertisements and is treated, by scholars and officials alike, as a "homogeneous spatial unit where indices of tradition and modernity can be measured." ${ }^{20}$ The imagery of this landscape and its people give a particular kind of Irish national identity "its ferocious enchantment" ${ }^{\text {"1 }}$ - one that centers on rejecting the effects of colonialism and defining an identity based on ideas of authentic Irish culture.

The political and personal significance of landscape takes on another layer of meaning when placed within the context of the Irish diaspora. Studies of heritage tourism provide useful insights into the importance of travel to spaces of significance in the narratives of these first generation Irish Canadians. Paul Basu studies Scottish heritage tourism and explains that "Diasporic identity is defined by its relationship with a landscape other than that in which 'it' resides. It is defined by an 'other landscape', an 'elsewhere', which is as much a symbol as a physical territory." 22 Diasporic communities are historically bound together by a sense of belonging to one place but being in another.

\footnotetext{
${ }^{19}$ Graham, "Ireland and Irishness," 7. Catherine Nash is also interested in the politics of space and has written on how local histories in Northern Ireland offer an avenue to confront grander narratives of political and sectarian division. She argues that by focusing on the local, communities are able to identify common grounds, including a shared appreciation of the land itself. Catherine C. Nash, "Local Histories in Northern Ireland," History Workshop Journal 60 (Autumn 2005): 45-68.

${ }^{20}$ Nuala C. Johnson, "Making Space: Gaeltacht policy and the politic of identity," in In Search of Ireland: A Cultural Geography, ed. Brian Graham (London and New York: Routledge, 1997), 174.

${ }^{21}$ Schama, Landscape and Memory, 15.

22 Paul Basu, Highland Homecomings: Genealogy and Heritage Tourism in the Scottish Diaspora (Routledge: New York, 2007), viii. (Commas written according to author's placement.)
} 
Basu argues that activities such as roots tourism and family history research contribute to the process of reterritorializing identity in binding the participants to both a place and a shared history. ${ }^{23}$ While the majority of my interviewees did not demonstrate much interest in the activities Basu examines (typically associated with second-, third-, and later generation immigrants), they did express a process of grounding themselves in a new landscape and relating it to the one they left in Ireland - a process connected to identifying with a new nation and negotiating memories of Ireland's past.

This experience is related by the author Salman Rushdie in his essay "Imaginary Homelands" in which he describes an old photograph of his childhood home in Bombay and the experience of revisiting that same house as an adult after living in England for many years. Reflecting on his experience, he contends that emigrants are haunted by a sense of loss and if they choose to look back to the land they left, they must with the understanding that, because they have been separated from their homeland for an extended period of time, "we will, in short, create fictions, not actual cities or villages, but invisible ones, imaginary homelands, Indias of the mind."24 The typically jarring impact migration had on an individual's embodied environment creates a need, as Parr notes, to shape narratives that make sense of this change and put it into the context of a life story and community history. ${ }^{25}$ As individuals and groups tell their stories about their migrations, the homeland is imagined and reimagined through the process of remembering. These stories change over time and develop along with the changing relationship migrants have with their new homes (for instance, stories of dislocation and

\footnotetext{
${ }^{23}$ Ibid., 10, 28.

${ }^{24}$ Salman Rushdie, Imaginary Homelands: Essays and Criticism 1981-1991 (New York: Penquin Books, 1992), 9-10.

${ }^{25}$ Parr, Sensing Changes, 8.
} 
loss may turn into stories of a fondly remembered place as the host country begins to feel more familiar and comfortable).

The complex history of colonialism also plays a significant role in these diaspora narratives. Basu notes the parallels commonly drawn by the participants in his study between their Scottish ancestors' history of dispossession and colonialism and the experience of First Nations peoples in North America and Australia. He points out that this comparison is problematic as the vast majority of his participants are middle-class, white settlers who are currently profiting from the continued colonization of First Nations, whether they mean to or not. ${ }^{26}$ One Australian participant noted this issue in an online forum and wrote, "I sometimes wonder if part of the longing for a homeland is a longing for a place of uncomplicated belonging." 27 Basu picks up on this phrasing, arguing that Scotland offers these participants a sense of their own indigeneity, while also allowing them to identify with the oppressed rather than the oppressors. The language of diaspora provides them with a way to express their feelings of alienation from their current home and to connect them with the history of a particular people. ${ }^{28}$

My interviewees, like all settlers (including myself), also benefit from the historic dispossession of First Nations in Canada. However, unlike Basu's Scotland, Ireland does not present itself as a land of "uncomplicated belonging." Rather, it is a place of intense complexity due to their personal experiences in the space as well as their eventual choice to remain in Canada. When I asked Tom whether he still thinks of Ireland as home, his

\footnotetext{
${ }^{26}$ Settlers here refers both first generation settlers to colonial spaces as well as their descedants. For more on Canadian settler relations with indigenous peoples, see: Paulette Regan, Unsettling the Settler Within: Indian Residential Schools, Truth Telling, and Reconciliation in Canada (Vancouver: UBC Press, 2010).

${ }^{27}$ Basu, Highland Homecomings, 207.

${ }^{28}$ Ibid., 199-211.
} 
answer reflected the complex relationship with Ireland and Canada expressed by most of my interviewees. He began his answer with a story about a friend from Eastern Europe who still sees his country of origin as "his country." When Tom pressed him on this point, he explained that Canada would never be his country, even though he likes living in Canada and has no plans to leave. Tom explained:

$\mathrm{T}:[\mathrm{In}]$ my conversations with him, I've become more clear in myself. A roundabout way to getting to your answer, but it's a complicated answer. Like, it-well, it's a complicated thought process because it's your emotions and your soul and your heart, right? And it's all mixed up in there and it's very hard... Can I ever not be Irish? No. Am I Irish? Yes. Am I Canadian? ... Yes. And I don't mean that as a hesitation. I mean it as ... I am Canadian, and I love Canada, and I won't go back to live in Ireland, and will spend-I will be buried in-in Canada. And my kids are Canadian. Although one of them is going off to Australia, but they're Canadian. But they're Irish Canadian. [...] I've been able to do an awful lot of things that I couldn't in Ireland. But I still love Ireland. I love the culture, I love the heritage, I love the people, I love the fun, I love the crack, I love the humour. I can walk into any pub and-in anywhere in the world and meet another Irishman and we're abusing each other and telling stories and jokes and all the rest of it as quick as a minute.

$\mathrm{K}$ : Yeah.

T: But I can also go traveling all over the world and wear my Canadian flag on my backpack. And-and talk about Toronto, and Vancouver Island, and- and Dawson City, and Nunavik, and Winnipeg, and it's great. So, yeah. But Canada's home. Win-actually, more specific than that, Winnipeg is home. Winnipeg is home because- because my wife's family and my family are here. ${ }^{29}$

Rather than longing for "a place of uncomplicated belonging," Tom lingers in duality; he is both Irish and Canadian. He has found a compromise particular to him that reconciles these relationships and enables him to be content in his decision to remain in Canada. ${ }^{30}$ Other interviewees described similarly complex connections with the two countries and found their own ways to come to terms with and describe their migration experience.

\footnotetext{
${ }^{29}$ Tom Naughten, interview by Kathryn Boschmann, Winnipeg, Manitoba, 19 June 2014, Part 2.

${ }^{30}$ As mentioned in Chapter 1, Tom told me that he and his wife Heather had discussed returning to Ireland but chose not to because of the kinds of questions they would be forced to ask as a Catholic-Protestant couple. Ibid.
} 


\subsection{Spirits and land}

One common way to discuss complex ties with the Irish landscape was to draw on spiritual language and religious references. Elsewhere in our conversations, Tom described his connection to the land and historical memories of Ireland in this way:

Okay, well, let me put it a weird way to you. I can never get the Ireland out of me because there's too many ghosts. The spirit of the land. I mean, when I go walk in Ireland there's a spirit you can feel. It's ancient. I mean, it's-you know, you turn any corner in Ireland and you're coming up against a bunch of vertical stones or something that, you know, have been part of something for thousands of years. [...] Because, you know, the Celts before in Ireland did-they-they were in touch with the land a lot. And we are. We-we all grow out of the land. [...] I can give you tons of stories of ghosts. That-ghost stories that my father taught me, but also ghost stories that I felt. You know, camping and-and things I can't explain. But feelings of spirits and places I've been. And I could go back and feel them again now. I'd tell you exactly where they are. [...] And there's spirits, and there's feelings, and there's ancient feelings. And I've only ever once, once, felt a spirit in Canada. [...] And I don't know whether it's me and this is an alien Canada. An alien land that-that I haven't grown up with. Or... or what? ${ }^{31}$

By being in the land, Tom encounters Ireland's past - through ancient stones and spirits.

Connections between soul and land were drawn by several of my interviewees, often to describe their feelings towards the different environments they have inhabited, particularly concerning belonging or estrangement to a certain place. These kinds of descriptions have points of commonality with Scottish heritage tourists' search for a land "of uncomplicated belonging," particularly in expressions that gesture to being indigenous to a particular landscape. Even so, this is typically tempered by interviewees' experiences of having lived in these places and acquiring intimate knowledge of the complexities of belonging. Moments such as these in the interviews demonstrate the emotional significance of landscape and weather. They also show how embodied

${ }^{31}$ Tom Naughten, interview by Kathryn Boschmann, Winnipeg, Manitoba, 10 June 2014, Part 2. 
experiences of place are tied to memory and history and form part of an affective repertoire drawn on to transfer meaning.

In my interview with Greg, we spoke several times about his deep emotional connection to Ireland (particularly Belfast) and the way he told his story reveals the link he makes between land, history, and emotional healing. Leaving Belfast was a very difficult experience for Greg and he told me that he spent much of his life in an identity crisis, longing for Ireland but tied to Winnipeg through family bonds. He described a trip he took in 2003 with the purpose of coming to terms with the conflict in Belfast and to resolve his emotions about living in Canada. He told me about how he walked through "the bitterest areas of Northern Ireland, of Belfast itself. Looked around, looked at the murals, looked at the cancer." ${ }^{32}$ He scrutinised how the places he played as a child had changed, some of which had taken on more signs of the conflict (such as flags), and explained, "I'm just, like, very angry. Very bitter. And I says, 'I came back for this rubbish? Right. That's it. I'm done.' So, I basically flushed it out of my system and came back here." ${ }^{33}$ In this story, there is a process of moving through spaces and intentionally confronting the associated and violent past. It is only through this deliberate engagement with place, its history, and his own emotions that Greg felt he was able to move beyond his feelings of dislocation.

However, it is important to note that this did not mean the end of his connection to Ireland. In 2012, Greg left a difficult job with an atmosphere he found poisonous:

\footnotetext{
${ }^{32}$ Greg McVicker, interview by Kathryn Boschmann, Winnipeg, Manitoba, 28 July 2014.

${ }^{33}$ Ibid.
} 
G: So, I went home again, to find myself once again. My safe place is home. So the place that caused me so much bitterness and grief and strife, is also my safety blanket. I don't know how else to describe it.

K: Yeah.

G: So I went home, but I flew into Dublin. And I'm in Dublin airport looking north to Belfast on July 11th and I'm going, "It's the 12th. It's the marches. It's the marching season." And then I'm looking to the west. And then I'm looking north. I'm looking west. I'm standing there for half an hour in the middle of a carpark, looking like a right idiot. Trying to figure out, where do I go? Where do I belong? Nobody knew I was home.

K: Right.

G: I just went home on me own accord. And I went west. To go back to a place where I was 32 years prior. And also in 1998 when my aunt and uncle had taken me. To lose myself in parts of Ireland that were very spiritual. Because I couldn't go into the marching season. ${ }^{34}$

Once again, Ireland was a place of healing for Greg, only this time, confronting the violence of the past was something he desired to avoid. Greg chose not to go to Belfast because of the July 12 Orange parades which commemorate the King William III's defeat of the Catholic King James in the Battle of the Boyne in 1690. As mentioned in Chapter 1, from the late 1960 s on, these public performances generated a great deal of tension and violent confrontation as they dealt with fiercely guarded identity boundaries between Catholics and Protestants in Northern Ireland, particularly in urban centres. ${ }^{35}$ Rather than confront that history again, Greg chose travel to the west of the island.

The west coast of the island, as noted earlier, continues to be viewed as most 'authentically Irish' in terms of traditions and landscape by locals and visitors alike. The rugged cliffs, green rolling hills, and the ocean of the western counties are typically foremost in the popular portrayal and imagination of the landscapes of Ireland and

\footnotetext{
34 Ibid.

${ }^{35}$ Dominic Bryan, "Parade Disputes and the Peace Process,” Peace Review 13, no. 1 (2001): 43-45.
} 
reaffirm the 'Irelands of the mind. ${ }^{36}$ This was made apparent to me when I visited Doolin, situated on the west coast. I encountered some American children who were visiting the village as a part of a large family gathering that recurred every five years. As we chatted, one of the children exclaimed that he liked Doolin the best because it has the best views and is the most Irish. Even among these young visitors, there was a sense of what it means for a place to be or look "Irish" and the west coast encapsulated that best in their minds. When Greg felt a need to stabilize and reconnect with his Irish identity but found it emotionally distressing to return to Northern Ireland, he turned to the west. It is possible that the west of the Republic of Ireland had a strong draw for him because of the engrained associations with Celticism, indigeneity, and nationalist understandings of Irishness. These emotional journeys enabled Greg to engage with both the difficult and the healing aspects of Ireland's past and ground him in a sense of self and time.

Basu notes how heritage tourists often refer to their trips as pilgrimages: "an outward physical journey through concrete space to a geographically-defined center, with a concomitant inward spiritual quest." ${ }^{37}$ He suggests that the trend of framing visits to these personally significant places in spiritual terms points to the emotional importance of these moments and the type of familiar narratives these individuals draw on to make sense of their experience and communicate its importance to others. ${ }^{38}$

While my interviewees' connections to places in their homeland differ from those who participated in Basu's research (who generally have few, if any, direct personal

\footnotetext{
${ }^{36}$ Johnson, "Making Space," 174-184; John Wilson Foster, "Encountering Traditions," in Nature in Ireland: A Scientific and Cultural History, ed. John Wilson Foster (Montreal and Kingston: McGillQueen's University Press, 1997), 25. Note that the quote is referencing Rushdie's "Indias of the mind."

${ }^{37}$ Basu, Highland Homecomings, xii-xiii. Basu is quoting J. Snelling, The Sacred Mountain: The Complete Guide to Tibet's Mount Kailas (London: East-West, 1990).

${ }^{38}$ Basu, Highland Homecomings, 56-59, 163, 184-186.
} 
memories attached to the places they visit), his treatment of pilgrimage is still useful for my analysis. For example, Tom told me about a trip he and his family were planning for the summer of 2014 and explained the importance of returning to a particular beach in Ireland that had considerable emotional significance for his wife, Heather.

T: And there's a-there's a place called Roundstone, which is just outside Galway. $[\ldots]$ Roundstone is a beautiful beach. And there's big rocks and there's a camp ground there that Heather's mom and dad used to bring a trailer to. And the two girls and Eileen would stay there all summer and Ralph would come and visit all the time. Commute and then take his holidays there. And-and so, it was a different time. So, in the morning the kids would be shooed out and off they'd go and they'd come back at lunch time for something to eat because they'd be hungry and then they'd go out and be shooed out and off they'd go again. So they had incredible freedom. And so, Kathy and-and Heather remember it with great fondness. And so in the rocks, there's particular rocks that they played in as kids. And so there was the kitchen and there was the sitting room and there was the dining room and all that stuff, that they had their specific rooms.

$\mathrm{K}$ : Yeah.

T: And like girls they played- that was where they played. And, so I call it the pilgrimage. And-and, so every time we go back, Heather has to go back to those rocks. And just spend a little time there and let the sea spray hit her in the face and she can taste the sea and the salt. And so we do that and we'll go back with all of them and walk that beach again.

$\mathrm{K}$ : Yeah.

T: It's important. ${ }^{39}$

This space is clearly deeply connected to some of Heather's important and, by all accounts, happy childhood memories in Ireland. Tom's choice of words to describe their visit to Roundstone suggests that there is something spiritual and restorative about this place and ocean itself. There is a sense of homecoming in these visits - that, according to Tom, being in Roundstone reaffirms Heather's sense of identity that is connected to that space and grounds her in a sense of time. ${ }^{40}$ In addition, this pilgrimage not only involves

\footnotetext{
${ }^{39}$ Tom Naughten, interview by Kathryn Boschmann, Winnipeg, Manitoba, 10 June 2014, Part 2.

${ }^{40}$ John C. Walsh, "Performing Public Memory and Re-Placing Home in the Ottawa Valley, 1900-58," in Placing Memory and Remembering Place in Canada, eds. James Opp and John C. Walsh (Vancouver: UBC Press, 2010), 26; Paul Basu, "Roots-tourism as Return Movements: Semantics and the Scottish
} 
looking at the landscape and the ocean, but, to borrow from Ingold, mingling with it feeling and tasting the sea spray. ${ }^{41}$

The notion of pilgrimage also features in Brian's play, Now You are Everywhere, about the time he spent busking on the Cliffs of Moher. When the main protagonist Rich E. enters the stage, he looks over the cliffs and says, "There you are, standing atop a sheer drop of seven hundred feet of rock to the sea, stretching on either side of your periphery as you stare westward into a horizon of ceaseless water, an ocean away from the next diocese: Newfoundland. Pilgrims, fall on your knees. Pause. Follow the pilgrims. Upward and onward!"42 Rich E's comment provides insight into the kind of experience visitors search for and, if the weather is good, experience when they visit the Cliffs. A few hours there offers an encounter with the sublime - a sense of awe and reverent fear when faced with something that is beyond the ability to express or fully know. $^{43}$

Diaspora," in Emigrant Homecomings: The Return Movements of Emigrants, 1600-2000, ed. Marjory Harper (Manchester: Manchester University Press, 2005), 133.

${ }^{41}$ Ingold, Being Alive, 115. Childhood also plays a significant role in many of these emotional memories of space. For more on space and childhood see: Barbara Lorenzkowski, "The Children's War," in "The Children's War," in Occupied St. John's: A Social History of a City at War, 1939-1945, ed. Steven High (Montreal and Kingston: McGill-Queen's University Press, 2010): 149. Alvin K. Lukashok and Kevin Lynch, "Some Childhood Memories of the City," Journal of the American Institute of Planners 22, no. 3 (1956): 142-152.

${ }^{42}$ Brian Richardson, "Now You Are Everywhere," (unpublished play, 2014, courtesy of the author), Word file.

${ }^{43}$ Philip Shaw, The Sublime (London and New York: Routledge, 2006), 2-6. This is a feeling typically associated with religious experience and/or the observation of spectacular sights in nature, such as towering mountains, endless oceans, and rugged cliffs. Environmental historian and geographer William Cronon has explored and complicated the idea of wilderness, illustrating how this human construct has acquired meaning over time. The imagery of wilderness now has remarkable power in human imaginations and Cronon notes that "To gain such remarkable influence, the concept of wilderness had to become loaded with some of the deepest core values of the culture that created and idealized it: it had to become sacred." William Cronon, "The Trouble with Wilderness; or, Getting Back to the Wrong Nature," in Uncommon Ground: Rethinking the Human Place in Nature, ed. William Cronon (New York: W.W. Norton \& Co., 1995). 73.

For more on the Cliffs of Moher, see: Adam Kaul, "Music on the edge: Busking at the Cliffs of Moher and the commodification of a musical landscape," Tourist Studies 14, no. 1 (2014): 30-47. 
Despite the number of tourists that fill the Cliffs daily (like many places in Ireland, the landscape has been heavily commodified), there is a sense in both the play and our conversation that it has not lost its spiritual and emotional quality for Brian. The last scene involves a reading of a poem written by Rich E. about the Cliffs and the friends he has made there. Spiritual language is used throughout and the final stanza reads, "Absorb us as the atmosphere, / we, the makers of ambience, / deepen the travelers' experience; / we, purveyors of memory, / touchstones to magnificence; / we, the shrines' inhabitants, / share the story, the might and glory / of water, land, air, and sun." ${ }^{24}$ The readers of the poem ("we") are presented here as being part of the Cliffs, mediators between memory, environment, and the visitors who come to take in its splendor.

References to pilgrimages and other kinds of spiritual encounters communicate the kind of emotional and embodied experiences of being in and connected to a certain geography. As Tilley suggests, landscapes are infused with individual and collective memory and it is in these memories that we base our sense of identity. Being in these spaces connects us to those memories and, while we might change over time, there is a feeling that the land will always be there, available to remind us of who we were and reassure us of who we are now.

However, those places that restore us may not always be readily available and there might be a need to find other ways of connecting to that landscape. Eileen told me that, while she now felt at home in Manitoba's wide open spaces, her husband Ralph did not feel entirely the same way. We talked about their regular trips to Ireland, and she explained:

\footnotetext{
${ }^{44}$ Richardson, "Now You Are Everywhere," Word file.
} 
E: It's not so much important for me but Ralph loves to get back to Ireland.

$\mathrm{K}$ : Yeah.

E: Whatever he feels, it's something, um, I guess there's no place that fills him like the way Ireland does.

K: Right.

E: Like, he paints, but he paints-everything is Irish. It-like, Irish scenes. He's not into painting Canadian landscapes.

$\mathrm{K}$ : It's Irish.

E: You know? So it's-it's-he still has that connection I think. More-more than I have. My-well, I wanted to go back because of my family. And I still go back to see my brother, because he's not well enough to travel here. But it's not, I don't feel the pull that he does. ${ }^{45}$

Along with the mention of the importance of revisiting a place in terms of spiritual fulfillment, Eileen observes that painting is another way that Ralph demonstrates and actualizes his continuing connection to the landscape of Ireland. Like Ralph, Shirley also paints nature scenes, but when I asked her what she draws from when she creates she explained, "Um, photographs, nature, the sea. I love the sea. I'm going-I'm going to go see the sea when I go home. I want to go see the sea. Um, clouds. Sunsets. I love the sunsets in Winnipeg. It's absolutely beautiful. That-that I love." ${ }^{\prime 46}$ While she misses the land and seascapes of Ireland, she also draws from Manitoba scenery in her art.

Artist and scholar Judith Tucker considers painting to be a way of affectively engaging with memory and place and connects this action to Marianne Hirsch's concept of postmemory. ${ }^{47}$ Tucker draws on her own experiences of painting German landscapes her Jewish grandmother visited while on holiday before the outbreak of World War II. As she creates, she examines the traces of pain and pleasure within the landscape and the

${ }^{45}$ Eileen Baxter, interview by Kathryn Boschmann, Winnipeg, Manitoba, 04 July 2014. To listen to more of this clip, see: http://beingirishontheprairies.ca/\#!/i-dont-feel-the-pull-that-he-does

${ }^{46}$ Shirley Foamete, interview by Kathryn Boschmann, Winnipeg, Manitoba, 17 October 2014. For more on Shirley's relationship with Ireland and Winnipeg, see: http://beingirishontheprairies.ca/\#!/people-think-imweird-because-like-why-winterpeg

${ }^{47}$ Hirsch defines postmemory as "the relationship of the second generation to powerful, often traumatic, experiences that preceded their births but that were nevertheless transmitted to them so deeply as to seem to constitute memories in their own right." Marianne Hirsch, "The Generation of Postmemory," Poetics Today 29, no. 1 (Spring, 2008): 103. 
past which haunts these vacation locations. Reflecting on this experience, she argues, "visual investigations actually become a kind of interrogation of place: operating as a journey to the past through an embodied investigation of the now." ${ }^{\text {"48 }}$ Tucker's engagement through space is more concerned with confronting and coming to terms with a space's past, while Shirley's and Ralph's engagement with the scenes they create appears to be more about celebration or love of a particular landscape or scene. However, Tucker's observation about painting as an embodied way of engaging with a space provides a compelling analytical framework, especially if we compare Shirley's and Ralph's choices in their painting. While Ralph continues to feel most fulfilled in Ireland's geography, Shirley feels relatively at home in Manitoba. Their painting, then, reflects their emotional engagement with the spaces around them.

\subsection{Locating home: Leaving Ireland and imagining Canada}

While most interviewees discuss continued emotional and spiritual connections with Ireland, many also spoke to how their relationship to the prairies has also developed over time and their narratives about this changing relationship are often connected to how they identify with Canada. This process is beautifully illustrated in the story of Maureen's migration experience, which I will expand upon here. Maureen described a significant shift in the way she related to Manitoba and Canada in our conversation. She described finding the prairie province at first as unwieldy and boring and said that the landscape contributed to the deep sense of loneliness she felt during her first years in Canada. She missed Ireland desperately, particularly walking the streets of Dublin and being such an

\footnotetext{
${ }^{48}$ Judith Tucker, "Brooding on Bornholm: Postmemory, Painting and Place," in Geography and Memory: Explorations in Identity, Place and Becoming, eds. Owain Jones and Joanne Garde-Hansen (New York: Palgrave Macmillan, 2012), 69-73, 81.
} 
easy drive from either the mountains or the ocean. This was enhanced by the amount of time it took (and still takes) to get anywhere outside of Winnipeg - a task which typically involves lengthy drives through long stretches of flat, empty, and seemingly undifferentiated expanses. ${ }^{49}$ She explained:

M: It took 2 good years of loneliness and regret and...

$\mathrm{K}: \mathrm{Mm}-\mathrm{hmm}$. Homesickness.

M: Homesickness, yeah. Until, until that began to sort of fade. ${ }^{50}$

As she made friends and joined local communities, Winnipeg began to feel more like home. However, as she and her husband Hugh drew closer to retirement, they began to talk about moving back to Ireland. The impetus for this mostly came from Hugh who Maureen described as having developed a hankering after Ireland. She thought it might be a good idea and they bought an acre in the Irish countryside. While she was hesitant about living in such an isolated area, she decided that it would be a nice change after a busy life in Winnipeg. However, it became apparent to her rather suddenly that she did not want to leave Canada in what she calls "the crisis of the cows."

M: About 3 years before we were going to retire to Ireland, Hugh and I were driving around the area where we were going to live. And Hugh stopped the car because there was a herd of cows and, you know, Hugh was admiring them. And I just burst into tears. And I said, "I don't want to do this. I can't think of living here." So we had a very hard time. It was a very, very hard time. And he was terribly upset, of course, because here was the wife saying, "I can't do this." You know?

$\mathrm{K}$ : Yeah. I guess it would be doing that whole thing over again.

M: Well, it-I think that was when I finally came to the realization, "I don't want to leave Canada. I just don't want to live in Ireland.” And I certainly didn't want to live in the country. I had been raised in the country. I loved it. I was very happy. But I-I was happy to go to Dublin and leave and live. So I didn't-didn't like this idea at all. So we had a very hard time trying to come to grips with that. ${ }^{51}$

\footnotetext{
${ }^{49}$ Maureen Taggart, interview by Kathryn Boschmann, Winnipeg, Manitoba, 17 June 2014, Part 2.

${ }^{50}$ Maureen Taggart, interview by Kathryn Boschmann, Winnipeg, Manitoba, 17 June 2014, Part 3.

${ }^{51}$ Ibid.
} 
Unfortunately the move back to Ireland was plagued by one difficulty after another. Maureen broke her wrist in the process of packing, the house in the countryside was unfinished when they arrived - without heat, electricity and water - and the Canadian maple floor they put in had buckled. In addition, Maureen does not drive which contributed to her feelings of isolation in rural Ireland. She explained that she was desperately lonely for Canada and the friends they had there. Her efforts to adjust were not aided by the weather they experienced which she characterized as "constant rain. Dampness. The sky, unlike Winnipeg, always seemed to be close to the ground." 52

To help move herself forward and build a community in Ireland, she decided to sign up for an acting course and was pleased to find that one of the instructors was a Canadian with whom she could swap stories about Canada. He was from Edmonton and explained to her that he had never been as cold in his life as he was in Ireland, despite the milder temperatures. After Maureen shared this anecdote with me, the two of us fell to comparing the damp cold in Ireland and the United Kingdom (which I had some experience of through my travels) versus the dry winters of Manitoba. ${ }^{53}$ These kinds of exchanges show how weather features in a shared environmental repertoire where experiences can be compared and shape how we understand a place.

Eventually the couple concluded that the move was not working out as they had hoped and they decided to return to Winnipeg. ${ }^{54}$ Maureen explained:

M: What did it for us was just missing Canada.

$\mathrm{K}: \mathrm{Mm}-\mathrm{hmm}$.

\footnotetext{
${ }^{52}$ Ibid.

${ }^{53}$ Ibid.

${ }^{54}$ The Winnipeg Free Press published an article about the couple's return to Winnipeg. "Irish eyes not smiling - till they're back in the city," Winnipeg Free Press, 17 April 2004.
} 
M: You know? And, um, at the end of the day, now-this is the interesting thing. If I'm watching something on television and I see pictures of Ireland, initially in the 70s, I would have thought, "Oh my god, I want to be there. This is what I love. You know, these-this is the-this is the landscape that I want to be in." And now, while I admire it and it's very beautiful, it's a lovely country, um, it's-it's snow and mountains and it's- that's what does it for me now. So-so I'm Canadian.

$\mathrm{K}$ : Yeah.

M: That's it. At the end of the day, I'm-I'm Canadian. ${ }^{55}$

The comment about identifying with mountains is interesting as Maureen has lived in the flat prairies for so long, but it makes sense as the Rocky Mountains have a strong association with Canada. This connection has been examined in studies such as James Opp's analysis of his parents' photograph collection. While his parents' property in Alberta was situated between prairie farmland to the east and ranches in the foothills of the Rockies to the west, Opp notes how their photography outings typically headed towards the mountains. Pictures of the prairies were primarily of the family farms, while the landscape photos that attempted to capture a sense of the Canadian wilderness tended to feature the Rockies. ${ }^{56}$ This could be due to the experience of the sublime evoked by scenes of the mountains. The Rockies have a prominent place in Canada's imagined landscape, similar in some ways to the imagery of the west coast of Ireland.

Maureen's story is significant for this study, not only because it demonstrates how landscape and climate feature prominently in the adjustment to a new place, but also because of the emotional connection she makes between landscape and weather and how she relates that to belonging to a certain nation. This comment is consistent with Benedict Anderson's concept of imagined communities, the phenomenon of individuals feeling

\footnotetext{
${ }^{55}$ Maureen Taggart, interview by Kathryn Boschmann, Winnipeg, Manitoba, 17 June 2014, Part 3.

${ }^{56}$ James Opp, "Finding the View: Landscape, Place, and Colour Slide Photography in Southern Alberta," in Placing Memory and Remembering Place in Canada, eds. James Opp and John C. Walsh (Vancouver: UBC Press, 2010), 273-275.
} 
that they are, in some way, united with those they have never met simply by virtue of living within a particular political boundary. People identify so strongly with their national community that many are willing to sacrifice their lives for it in times of crisis. Anderson argues that cultural products, such as media and a shared language, play a central role in developing and maintaining this imagined community. ${ }^{57}$ The narratives of my interviewees suggest that the experiences of landscape and climate create a shared environmental repertoire which informs how a community is conceptualized.

\subsection{The winters of our discontent: Weather in Manitoba and Ireland}

Tom indirectly commented on Canada's imagined community when he admitted that he was surprised there was anything at all in common for Canadians to grasp onto.

$\mathrm{T}:[\mathrm{We}]$ have this expectation that Canada is one country. But it's the daftest expectation. Because if you go live out in the- on the East coast, you wear Macintoshes and everything has to do with rain. You come to Winnipeg and you have to survive Siberian cold. And you go to Vancouver, you know, and it's moist humidity. You know? And sloppy snow.

K: Yeah.

T: And you go up to the Yukon, and it's, again, the same cold but maybe not the wind of-of here. And then, you go to-to, um, Inuvik, or something and it's cold and no light. You know? [...] In the-in Dawson, at least, at-at lunch time, when you came home for lunch you got a kind of a grey haze. Otherwise it was dark the rest of the time. Um, but in-in Inuvik and higher and some of those small places, you know? Nothing. You're going to get no light for many, many months. And it does things to you.

K: Yeah. Yeah.

$\mathrm{T}$ : And in summer, you've got 24 hour sunlight. And it does things to you. $[\ldots]$

$\mathrm{K}$ : It's such a big country and we're all spread out so far.

T: And we expect it to be one country. We expect sameness. But with temperature, humidity, sunlight, hours of day light, all those physical difference. Permafrost. I mean, building on permafrost is a totally different deal than building here. Which is totally different than building out on a rock, you know,

\footnotetext{
${ }^{57}$ Benedict Anderson, Imagined Communities: Reflections on the Origins and Spread of Nationalism (London: Verso, 2006), 5-7, 9-12, 32-36.
} 
in- in Newfoundland. And we expect us all to be the same culture, even though we've got totally different environments? We've got different housing, different clothing, different food. We're strange.

$\mathrm{K}$ : Yeah.

T: You know, we-we keep fighting about, you know, Quebec wants to leave and Alberta wants to leave or BC wants to separate or whatever. And, we go, it's a bloody miracle we're all together, for cryin' out loud. You know? ${ }^{58}$

That Tom's assessment of Canadian identity is explicitly connected with its weather patterns demonstrates further the cultural weight of the environment in Canada. In our conversations, Tom explained the value that cultural performances, like traditional Irish music, dance, and theatre, had in his personal experience and to Irish people more generally. In contrast to this vibrant national culture, there is a sense that Canadians do not have the same kind of common cultural identity markers because the country's population is multicultural. These interviews suggest that climate takes on particular significance in this context because it represents something that many Canadians hold in common. However, as Tom points out, this is complicated since the climates across Canada vary so much. In my conversations with my peers in the History department, we often discussed the differences between weather patterns in our home provinces (or localities).

Indeed, weather played an important role in my interviewees' migration narratives - shaping their perceptions of Manitoba and Ireland and their environmental repertoire which then provided symbols and points of commonality used to communicate meaning in our discussions. The symbolic importance of weather is effectively illustrated in the collaborative performance piece called Patterns from Snow created by Brian and three

\footnotetext{
${ }^{58}$ Tom Naughten, interview by Kathryn Boschmann, Winnipeg, Manitoba, 10 June 2014, Part 2.
} 
other Winnipeg artists who had migrated from India, Nigeria, and Hong Kong. ${ }^{59}$ The four artists came together to discuss their migration experiences and found that they all had powerful reactions to their first encounter with snow. They developed a production that involved music and dance that referenced their different ethnic backgrounds as well as Brian's poetry and Chinese calligraphy. ${ }^{60}$ Brian later published the poems he wrote for this piece in a book under the same title. The first poem, entitled "Landscape to Personality", explores the land and climate of each artists' homeland, starting with Ireland:

\section{Ireland}

The sudden sodden soaking The showering rainbow The splash of sunshine The transient cloud shadows The twist of the road Winding in and out of the wind Climbing and clinging Awash in angles and bends An instant glimmer of the sea Landscape to personality, perception to psyche As changeable as an Irishman's mood ${ }^{61}$

What is interesting about this poem is that its title indicates that it is about landscape but much of this excerpt is concerned with weather. Brian's poem immediately points to the problem of excluding weather from the affective experience of landscape. The connection he draws between space and personality is not only defined by the lay of the land but also the climate that we experience when we are in that space. This reinforces Ingold's argument concerning the bond between landscape and weather. As he states, "creatures

\footnotetext{
${ }^{59}$ It is worth noting that the homeland climates of all four artists are all significantly milder than Manitoba's.

${ }^{60}$ Brian Richardson, notes from telephone interview by Kathryn Boschmann, 13 January 2015.

${ }^{61}$ Brian Richardson, Patterns from Snow: Poems, Patterns and Photography (Winnipeg, MB: Snacpress, 2001), 20.
} 
live in the land and not on it. ${ }^{{ }^{62}}$ We do not skim over the top of a landscape, impervious to its elements, but walk through its mud and sand, breathe in its air, shiver from the wind, and sweat from the heat.

Patterns from Snow as a whole powerfully illustrates the emotional significance of landscape and weather in the experience of migration and how these form an affective repertoire that can be used to communicate meaning. This also comes through in Brian's explanation of their choice to focus on snow:

B: So we wanted to explore that and the snow became the metaphor because the snow is powerful. It's beautiful, cold, and the-the incredible change that it makes and all of us responding to it because it's not something that was part of our-you know, I had snow as a kid but it would last a day. I remember when it lasted a week.

K: Yeah. Yeah.

B: Big thing, you know?

$\mathrm{K}$ : Yeah.

[...]

B: Um, so we used this as the metaphor. And then in spring, you watch it break up and change shape and form. And then it unleashes like-like a birth. The water breaks. And so we were, sort of, reborn into this. But we always-the-the line that I used constantly throughout it, "On a bridge I'm standing."

$\mathrm{K}: \mathrm{Mm}-\mathrm{hmm}$.

B: Because you are on that bridge between the two cultures always. ${ }^{63}$

Weather here becomes a compelling communicative tool in explaining the experience of migration to others. The audiences for whom the artists performed this piece may not have had personal experience of immigration but they did share the knowledge of the qualities of a Manitoban winter: the freezing temperatures, how long the winter lasts, how emotionally difficult it can be, and the relief of spring and the new life it brings. ${ }^{64}$

\footnotetext{
62 Ingold, Being Alive, 120. Author's emphasis.

${ }^{63}$ Brian Richardson, interview by Kathryn Boschmann, Winnipeg, Manitoba, 18 July 2014, Part 1.

${ }^{64}$ Winters in Winnipeg can reach an average low of $-21^{\circ} \mathrm{C}$ and can plummet to the -30 s which the wind chill often exacerbates. Some days the dry cold can feel like $-50{ }^{\circ} \mathrm{C}$. "Winnipeg deep freeze as cold as uninhabited planet," CBC News, 31 December 2013, http://www.cbc.ca/news/canada/manitoba/winnipeg-
} 
This performance piece, the accompanying volume of poetry, and Brian's description of them in our conversation touch on many important themes in this chapter. First, migration can bring a special kind of awareness to living in a landscape. Feelings of being out of place or in between lands and cultures draw attention to the difference between climates and spaces. Stories about experiences of weather, visits to particular places, and movement through spaces take on significance when they are used as a part of an environmental repertoire to communicate emotional processes involved in migration. ${ }^{65}$ Second, embodied experiences of place are tied to personal and collective memories which contributes to their effectiveness in the repertoire.

The performance piece also draws attention to the particular significance of winter in the repertoire of Canadians. This season is strongly associated with Winnipeg evident in its nickname "Winterpeg" which Shirley mentioned when we spoke. ${ }^{66}$ In my conversation with Pat, when I asked if his parents liked Winnipeg when they first settled there, his first response was “Well, I don’t think that- I don't think that anybody's keen on the winters. That's sort of one thing." ${ }^{97}$ This immediate reference to weather when discussing adjustment to Winnipeg was common in most of my interviews. Eileen, for example, responded in a similar fashion:

K: What about for you when you-when you first came here. What was that... E: When I first came here, the first winter-the first summer was fine. It was a beautiful summer.

\footnotetext{
deep-freeze-as-cold-as-uninhabited-planet-1.2479967; Canadian Climate Normals 1981-2010 Station Data, "Temperature and Precipitation Chart for 1981 to 2010 Canadian Climate Normals: Winnipeg Richardson Int'l A," accessed 05 August 2015, http://climate.weather.gc.ca/climate_normals/results_1981_2010_e.html?stnID=3698\&lang=e\&amp;Statio

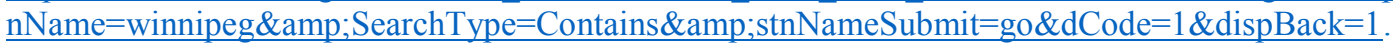

${ }^{65}$ Greg's description of his first experience of Winnipeg touches on many of these themes as well. See: http://beingirishontheprairies.ca/\#!/we-never-have-warm-wind-back-home

${ }^{66}$ Shirley Foamete, interview by Kathryn Boschmann, Winnipeg, Manitoba, 26 June 2014, Part 2.

${ }^{67}$ Patrick Gannon, interview by Kathryn Boschmann, Winnipeg, Manitoba, 25 June 2014.
} 
K: Yeah.

E: The first winter was very cold. And I used to help at a daycare and the daycare was just a few blocks from the rectory, from where we lived. And coming home in the afternoon, I thought I was going to die with the cold. And my knees. And I remember saying, "Why am I in this God-forsaken place?" I just felt so horrible about it. I really was cold. ${ }^{68}$

Winter plays a particularly important role in Eileen's migration narrative as she noted that this was the only time when she questioned why she had come to Canada. As Brian and the other artists involved in Patterns from Snow found, the cold and snow were powerful shared experiences and could elicit strong emotional responses, including feelings of isolation and a sense of being out of place.

\subsection{Gaining perspective: Movement and place}

Like stories about winter, stories concerning movement were also a common initial response to questions about adjustment to life in Manitoba. Ingold argues that movement is a crucial part of the perception of our environments:

As people, in the course of their everyday lives, make their way by foot around a familiar terrain, so its paths, textures and contours, variable through the seasons, are incorporated into their own embodied capacities of movement, awareness and response - or what Gaston Bachelard (1964:11) calls their 'muscular consciousness'. But conversely, these pedestrian movements thread a tangled mesh of personalized trails through the landscape itself. Through walking, in short, landscapes are woven into life, and lives are woven into the landscape, in a process that is continuous and never-ending (Tilley 1994:29-30). ${ }^{69}$

How we move is central to how we relate with our landscape. The emphasis in Ingold's work is on walking. He is somewhat dismissive of mechanical transportation, arguing that it moves across the land, rather than in and through the land. My interviews suggest, however, that to ignore this kind of transportation is to neglect a common way that people

${ }^{68}$ Eileen Baxter, interview by Kathryn Boschmann, Winnipeg, Manitoba, 04 July 2014.

${ }^{69}$ Ingold, Being Alive, 47. 
interact with the landscapes they inhabit. Driving was particularly significant as it commonly featured in stories of feeling out of place or, conversely, coming to feel at home in the prairies.

Human geographer Timothy Cresswell also draws attention to how mobility is crucial to our experience of the world and considers how the developments of transportation technology have shaped our concept of time and space. For example, the introduction of railway marked the first time people saw landscape move by in a steady blur from their windows. Trains seemed to shorten the distance between places and also, in North America, initiated strict regulation of time. In the 1860s, someone traveling across the United States or Canada would travel over two hundred time zones, since each locality had its own time based on exact longitude, measured by the apparent movement of the sun. This became a significant scheduling problem with the introduction of regular train travel so North America was divided into set time zones. This change in how people moved affected more than simply the means of getting from point A to point B. It also changed how people understood time and experienced geography. ${ }^{70}$

Transportation, time, and spatial awareness all played a part in how Joe and Brian responded to questions about acclimatizing to life on the prairies. Joe told me that before he came to settle in Manitoba, he visited his sister in Winnipeg for a couple of weeks. At one point in his stay, he and another priest went to visit a colleague in Brandon and Joe was invited to drive the way home. "And I'm driving and he said, 'You know, you can

\footnotetext{
${ }^{70}$ Tim Cresswell, On the Move: Mobility in the Modern Western World (New York and London: Routledge, 2006), 2-6, 21. For more on automobiles and space, see: Virginia Scharff, Taking the Wheel: Women and the Coming of the Motor Age (New York: Free Press, 1991); David Louter, Windshield Wilderness: Cars, Roads, and Nature in Washington's National Parks (Seattle: University of Washington Press, 2006).
} 
actually speed up. You're not going to-it's straight all the way.' [...] And if it's 70

kilometers, you get there in an hour. Exactly. Now, in Ireland, if you were traveling 90 miles, it would take you 3 hours. [...] So, no matter where I was traveling at the time in Ireland I-I gave myself an average speed of 30 miles an hour. No matter how fast I was driving. Well, you hit a town and you have to slow down to 30 an hour. You might hit a few cows on the road. You slow down again."

Brian shared a similar story about finding it difficult to judge distance and speed when he first drove in the prairies. After living in Montreal and Halifax, Brian made his way west with a friend who was originally from Winnipeg. They had made it to Kenora and it was Brian's turn to drive. He told me, “All of a sudden, the trees start to move aside. You're coming out. There's a car ahead of me. Start to slow down. Wayne says, 'What are you slowing down for?' I said, 'There's a car ahead of us.' He said, 'That's probably a couple of miles down the road. You don't need to slow down.' We carry on. I keep driving. He says, 'Okay. Slow down.' We're virtually at the guy's tail pipe. Uh, he says, 'You can overtake when you get the chance. Have a look.' I had not got the perspective to see, in terms of the size and the distance." 72

These stories demonstrate a sense of feeling out of place. Both Brian and Joe were at first unsure how to move appropriately through the prairies while driving, having never closely encountered that kind of space before. The same could be said for Catriona, only she was unfamiliar with driving through Ireland's landscape since she left Ireland as a child. She explained to me, "You can't go very far in Ireland. It takes forever. So, you know, it looks like, you know, it's only 80 kilometers but it's going to take you a day and

\footnotetext{
${ }^{71}$ Joe and Mary Campbell, interview by Kathryn Boschmann, Winnipeg, Manitoba, 17 July 2014.
}

${ }^{72}$ Brian Richardson, interview by Kathryn Boschmann, Winnipeg, Manitoba, 18 July 2014, Part 1. 
a half to get there. It's just ridiculous. ${ }^{, 73}$ Like Catriona, I was surprised at the stark difference between traveling through prairies as opposed to Ireland. When I traveled around Ireland in August 2014, I took a bus and found I was very uncomfortable with the constantly changing speeds and how fast we traveled over the narrow, windy roads. This, of course, is because I have mostly driven on wide, straight roads where towns are spread far apart and most travel is done at a steady pace. Like my interviewees, I was faced with a way of moving through a particular space that was not yet part of my environmental repertoire.

While these stories demonstrate a sense of feeling out of place, Eileen and Mary shared stories about driving that illustrated a turning point in their migration experience a point where they began to feel at home, or in place, in the prairies. Eileen explained that while she was always content to be in Winnipeg, the process of feeling at home was a gradual one. Ten or twelve years after moving to Manitoba, Eileen and her family took a road trip to Prince Edward Island. "And we came back. So we were away about 6 weeks. And I think when we got- crossed into Manitoba, I suddenly thought, 'I'm home."”74 She told me that this was the first time she had ever thought this and it is significant that this was precipitated by the movement from one province to another. The boundary between Manitoba and Ontario becomes infused with meaning - the crossing from a space where she felt she was visiting into a place where she felt belonging.

In this story, movement along a road makes possible visual cues that generate emotion - for example, a sign welcoming drivers to Manitoba. Traveling along these paths shape what Cresswell calls "people's geographical imaginations" which range from

\footnotetext{
${ }^{73}$ Catriona Younger, interview by Kathryn Boschmann, Winnipeg, Manitoba, 09 July 2014.
}

${ }^{74}$ Eileen Baxter, interview by Kathryn Boschmann, Winnipeg, Manitoba, 04 July 2014. 
personal ways of knowing a place to ways societies understand places and the relationships between them. ${ }^{75}$ As spaces become familiar and comfortable, their meanings change. This is apparent in a story Mary shared about a driving experience that changed the way she understood the prairies and produced a significant shift in her emotions towards Manitoba while driving:

M: I have to say. I-because, when I came, the first time, the thing I felt most was the spaciousness. And it was the thing that I noticed at the very, very beginning.

K: Right.

M: There was somehow that... it felt more spacious, somehow. And I do remember thinking for a long time how dreary the prairies looked. Until one March, I was driving out to Portage La Prairie with Rita for a drama thing. And it was just thawing and whatever look I gave at the landscape, if you like, I realized the whole place was just teeming with life. And it just turned my whole- I think that's when I started to really settle in Manitoba.

$\mathrm{K}$ : Yeah. Yeah.

M: To really put down roots and started to feel at home, you know? Not that I ever felt that alien or anything. I didn't. But, that-from that point onwards it became home for me. ${ }^{76}$

This story also points to an interesting connection between finding the beauty of a place and feeling at home within it. Like Maureen, Mary found the vast expanses of the prairies somewhat unpleasant and, although she explains she did not feel alienated, this difficulty with identifying with the landscape appears to have inhibited her from feeling entirely comfortable in the space. Environmental historian Claire Elizabeth Campbell talks about how locating beauty in a place that does not fit within conventional aesthetics of landscape often involves "an intimacy of locality." 77 Finding the beauty of the prairies was a process, and, for Mary, it was based primarily in seeing the life of this landscape.

\footnotetext{
${ }^{75}$ Cresswell, On the Move, 21.

${ }^{76}$ Joe and Mary Campbell, interview by Kathryn Boschmann, Winnipeg, Manitoba, 17 July 2014.

${ }^{77}$ Campbell, Shaped by the West Wind, 137.
} 
The fauna of the prairies contrasted with Ireland's landscape, which is relatively empty of wildlife, and brought awareness to the subtle beauty of Manitoba.

The connection between the process of finding the beauty of prairie spaces and feeling at home in Manitoba was a relatively common pattern among my interviewees. When I spoke with Brian about his experience of the landscape and adjusting to the openness, he explained: "It took forever. And Hugh and I used to talk about this. I would say to him, I'm starting to see the subtleties, I'm starting to see the colors, but it's this much of a plain. And I included that in Patterns from Snow. That the plain is, you know, a few degrees. That's it. That's what you're seeing. Everything in. The rest is sky." ${ }^{, 7}$ His poem in Patterns from Snow titled "Five Degrees" addresses this vast flatness of the prairies, capturing a feeling of exposure and dislocation.

Five degrees, perhaps, is all the land occupies

of the arc of sky. So little mass

to fill the vista of its three hundred and sixty around, one hundred and eighty over.

No mountains interpose.

No hills reduce the scope.

Some trees may occupy the nearby eye where they are close.

They stand high only beneath their realm of leaf and bark.

There is only distance on the plains, no sharp intersecting planes to allow the eye escape, nothing, only exposure.

Uncommitted to anything but space the landscape flattens, stealing the flattery of scale, in harsh dissecting light.

Much too visible.

Too much visible.

Nowhere for an anchor. ${ }^{79}$

\footnotetext{
${ }^{78}$ Brian Richardson, interview by Kathryn Boschmann, Winnipeg, Manitoba, 18 July 2014, Part 1.

${ }^{79}$ Richardson, Patterns from Snow, 20.
} 
This poem conveys the deep emotional effect the prairie landscape had on Brian and, in all probability, many other newcomers to Manitoba. Brian explained that he used to search for places in Winnipeg that would allow him a sense of rise in the landscape, spending time on Garbage Hill or going out of his way to drive over the steep incline of the Arlington Bridge. However, as he mentioned in the quote above, he began to find the restrained beauty of the space and found ways to cope with the discomfort (which he described as a mild case of agoraphobia). ${ }^{80}$

This adjustment is part of the process of incorporating a new space into an environmental repertoire. Brian and Joe familiarized themselves with the space by drawing parallels between the prairies and Ireland's environment: comparing the flat prairies to the ocean became a way of finding the sublime in Manitoba. Brian explained that he thought of the prairies as an ocean of dry. This sentiment was also apparent in another volume of his poetry called Reflections from a Basement Window, in which he wrote, "Like an island on the plain / looking out on a level land / surrounded by an ocean of grain / the concrete towers of the city stand." 81 This idea of towns and cities in Manitoba being like islands within the ocean was echoed in my conversation with Joe.

$\mathrm{J}$ : [Living] on the prairies and traveling on the prairies is like traveling through the Atlantic ocean. Here and there there's a village or a tower of an island. K: Yeah.

J: And, that's about it. There's nothing-absolutely, you know, nothing. And I remember when I was here in the- in the 70s for a while, my brother-in-law was working up in Jenpeg. Way north of here. And, I took my sister, and her child, and Mary and I, I took them up there. And, um, well, you get to Gillam or Gypsum or whatever. Gypsumville or whatever. And it says, "Nothing-no gas, no nothing for the next $300 \mathrm{~km}$." You know what I'm saying?

\footnotetext{
${ }^{80}$ Brian Richardson, interview by Kathryn Boschmann, Winnipeg, Manitoba, 18 July 2014, Part 1.

${ }^{81}$ Brian Richardson, Reflections from a Basement Window (Winnipeg, MB: The Prairie Publishing Company, 1983), 74. For more on Brian's comparison of the prairies and the ocean, see: http://beingirishontheprairies.ca/\#!/ive-always-tried-to-live-close-to-the-water
} 
K: Yeah.

J: So that's typical. It's like saying, "No island between now, so, you better be rowing well and... and so on."

K: Yeah, yeah. Fill up while you can.

J: Oh yeah. Oh, fill up while you can. So, I found-I find that that's more characteristic of here. Of-of Winnipeg-or Manitoba, than it is of the states. ${ }^{82}$

This kind of comparison between oceans and prairie fields is, I would argue, a way to incorporate a new space into our environmental repertoire. As Tilley has argued, making connections between the two kinds of vast open spaces, one of which is familiar and one of which seems foreign, helps make sense of the new space and gives us an idea of how to move through it comfortably. We draw on our memory of familiar spaces to give landscape meaning and, as Ingold notes, develop knowledge and identities that facilitate our lives within the new environment. ${ }^{83}$

\subsection{Conclusion}

I have argued here that Taylor's concept of repertoire can be expanded and applied to embodied experiences of landscape and weather and the narratives they produce. After we have repeatedly encountered an environment, we come to understand how to move and react to its elements appropriately. Facing an unfamiliar landscape can be a jarring experience and involves a considerable amount of adjustment. As we incorporate these new experiences into our spatial repertoire, we attach meaning to our encounters and draw on this to communicate with others.

Like the repertoire of Irish traditional performance, this environmental repertoire is connected to both emotions and politics. Images of places such as Ireland's west coast

\footnotetext{
82 Joe and Mary Campbell, interview by Kathryn Boschmann, Winnipeg, Manitoba, 17 July 2014.

${ }^{83}$ Ingold, Being Alive, 129; Tilley, Phenomenology of Landscape, 10-15.
} 
and the Gaeltacht regions were mobilized in nationalist movements to establish a particular vision of an authentically Irish landscape and people. This was, in part, a reaction against colonialism and reinforced a sense of indigeneity and ownership of the land. Many of my interviewees described spiritual connections with the landscape of Ireland, and revisited certain places to reconnect to the past, search for healing, and regenerate their sense of identity. However, this sense of belonging has been complicated by the process of relocating home in Winnipeg. Stories about dealing with Manitoba winters and moving through the flat expanse of the prairies were often connected to narratives about both feeling out of place and finding home. Interviewees drew upon these experiences effectively to communicate the emotional impact of migration.

These interviews point to the significance of repeated embodied encounters with two strikingly different environments. Taylor's concept of repertoire can encompass these experiences and help us to understand the role of landscape and weather in these migrant narratives. Environmental repertoires are deeply connected to memory (both personal and collective) and to emotional connections to the places we have inhabited. As landscape and weather patterns are invested with meaning, they gain political power as compelling images within communities' international, national, and local imaginations. In addition, this repertoire does important personal emotional work. As we expand our repertoires, we open doors of communication with those whose repertoires overlap with our own. This provides a kind of common ground which facilitates communication not only about environmental experiences, but also our emotional lives and feelings of belonging. 


\section{Conclusion}

The stories told here draw attention to how people, as individuals and as communities, relate to the past in changing circumstances. As Greg Dening stated, "We all make histories endlessly. It is our human condition to make histories. No sooner is the present gone in the blink of an eye than we make sense of it as past. We tell stories about it. We interpret meaning of the gestures made, of words spoken, of actions done. We make a narrative of the past in our mind, in our conversations. ${ }^{1}$ We are constantly telling stories about our personal and collective pasts and the narratives we create reflect our context and self-understanding. I have argued that Diana Taylor's concept of repertoire can give insight into the oral history migration narratives of first generation Irish Canadians in Winnipeg. As actions are repeated and incorporated into an embodied archive, they acquire significance which can then be drawn upon to communicate meaning to others. These interviewees, who were generally exceptionally active in creative pursuits (including music, theatre, and writing), described in our conversation their engagement with cultural and spatial repertoires. Examining their stories through this lens reveals how memory and historical politics manifest in participation in cultural performances and interactions with the environment.

In Chapter One, I demonstrated how traditional performances are profoundly connected to Ireland's political past. As they were mobilized for nationalist and cultural expression, they developed a provenance, or associations with a particular history. This provenance is what makes traditional activities meaningful expressions of Irishness for many interviewees, connecting them with a community and a history. However, when

\footnotetext{
${ }^{1}$ Greg Dening, Performances (Chicago: The University of Chicago Press, 1996), 35.
} 
individuals enter the new context of Winnipeg and form new Irish-Canadian communities this provenance can become divisive. As communities take steps to depoliticize spaces, such as the Irish Club, traditional performances become sites of memory tensions as lines between political and non-political are drawn within the communal repertoire.

The context of interviewees' lives in Ireland and the time they left have had a significant influence on their perceptions of traditional performances as well as their opinions on whether certain cultural activities or symbols should be included in the community's repertoire. For example, those who originated from the Republic of Ireland and immigrated to Canada in the 1970s as adults had experienced the cultural revivals which made these performances an effective means of identity expression. However, they were also keenly aware of the deadly conflict in Northern Ireland and expressed a desire to distance themselves from these politics. When the Irish Club was established in 1972, during the height of the Troubles, they believed it was necessary to restrict certain performances in the interests of inclusiveness. With greater historical and physical distance from the conflict of the homeland, some members (particularly the more recent cohort of immigrants and a younger generation of Irish Canadians) are beginning to push against the exclusion of certain performances from depoliticized spaces.

Those interviewees who came to Canada as children in the 1950s wave of Irish migration did not have the same kind of experience with the political nature of traditional performances (such as parades) and understood participation in these activities in a way that differed significantly from those who arrived as adults. Interviewees originating from Belfast had experienced state efforts to distance inhabitants from traditional activities precisely because of their political provenance. These individuals found it difficult to 
identify as strongly with these performances and did not find associations like the Irish Club particularly useful in establishing a personal sense of Irishness.

Chapter Two argues that the concept of repertoire can be extended to include experiences of landscape and weather as described by my interviewees. The sense of belonging to a place or, alternatively, feeling out of place, is connected to personal and collective memory. As individuals adjust to a new place, they incorporate new environmental experiences into their embodied repertoires and give meaning to these encounters with a place and its elements. Interviewees would draw upon this repertoire to communicate meaning to others who share parts of the same environmental repertoire. This repertoire can also be connected to a political past: the Gaeltacht has come to be associated with a sense of being authentically Irish and untarnished by British rule.

Several interviewees used spiritual and religious language to describe the type of connection they felt with the land of Ireland, a connection that is complicated by their choice to remain in Canada. Most described a long process of locating home in Winnipeg. Initial encounters were typically characterized by a profound sense of being out of place. The seemingly empty expanse of the prairies and the long, frigid winters were often referenced to describe intense feelings of isolation. Stories of driving were told by some interviewees to illustrate how strange the landscape felt in the beginning in comparison to the kind of movement they were comfortable with in Ireland. Movement could also generate new perspectives and facilitate a reconciliation with the new place: some interviewees came to discover the beauty of the prairies and find themselves at home while driving. Other interviewees made sense of Manitoba's flat landscape by drawing parallels with familiar Irish spaces, such as the ocean. These stories demonstrate 
the communicative power of environmental repertoires as well as the ways in which lives and biographies are woven into the landscapes we inhabit. ${ }^{2}$

The website builds on the analysis of performance, environment, and family histories by focusing on the emotional quality of certain memories. Emotional memories played a significant role in shaping the stories that are told and the way certain activities are understood and accessed. The audio clips featured on the website draw attention to the significance of listening to oral histories and the affective power of the voice. Hearing the ways these people speak and their process of narrating their experiences can contribute to a better understanding of the interviewee as an individual as well as the interview dynamics between interviewer and interviewee.

The stories reordered and analysed here are part of a larger story of migrant experiences in Canada. They draw attention to the ways in which political pasts are carried over to new places through the provenance of traditional performances and how communities responds to this history. They also demonstrate the significance of encounters with dramatically different environments and the ways in which these experiences are incorporated into stories about identity and belonging. This study shows the value of examining oral history narratives of adaptation and memory through the lens of repertoire. Applying this approach to the histories we create can draw attention to how the past is remembered by individuals, how those memories relate to collective narratives, and the ways in which people make sense of personal and communal memories.

${ }^{2}$ Christopher Tilley, Phenomenology of Landscape: Places, Paths and Monuments (Oxford and Providence: Berg Publishers, 1994), 27; Tim Ingold, Being Alive: Essays on Movements, Knowledge and Description (London and New York: Routledge, 2011), 47. 


\section{Bibliography}

\section{Interviews}

Baxter, Eileen. Interview by Kathryn Boschmann. Winnipeg, Manitoba. 04 July 2014.

Campbell, Joe and Mary. Interview by Kathryn Boschmann. Winnipeg, Manitoba. 11 July 2014.

Campbell, Joe and Mary. Interview by Kathryn Boschmann. Winnipeg, Manitoba. 17 July 2014.

Foamete, Shirley. Interview by Kathryn Boschmann. Winnipeg, Manitoba. 26 June 2014, Parts 1 and 2.

Foamete, Shirley. Interview by Kathryn Boschmann. Winnipeg, Manitoba. 17 October 2014.

Gannon, Patrick. Interview by Kathryn Boschmann. Winnipeg, Manitoba. 25 June 2014.

McVicker, Greg. Interview by Kathryn Boschmann. Winnipeg, Manitoba. 28 July 2014.

Naughten, Tom. Interview by Kathryn Boschmann. Winnipeg, Manitoba. 10 June 2014, Parts 1,2 , and 3 .

Naughten, Tom. Interview by Kathryn Boschmann. Winnipeg, Manitoba. 19 June 2014, Parts 1, 2, and 3.

Richardson, Brian. Interview by Kathryn Boschmann. Winnipeg, Manitoba. 18 July 2014, Parts 1 and 2.

Richardson, Brian. Notes from telephone interview by Kathryn Boschmann. 13 January 2015.

Slater, Sharon. Interview by Kathryn Boschmann. Limerick, Ireland. 17 August 2014.

Taggart, Maureen. Interview by Kathryn Boschmann. Winnipeg, Manitoba. 17 June 2014, Parts 1, 2, and 3.

Taggart, Maureen. Interview by Kathryn Boschmann. Winnipeg, Manitoba. 30 June 2014.

Younger, Catriona. Interview by Kathryn Boschmann. Winnipeg, Manitoba. 09 July 2014. 


\section{Memoirs and fiction}

McVicker, Greg. An Irish Heart: Journey of a Belfast Child. Winnipeg, MB: Greg McVicker, 2014. Kindle Edition.

McVicker, Greg. Silly Billy and the Postage Stamp. Winnipeg, MB: Greg McVicker, 2015. Kindle Edition.

McVicker, Greg. Through the Eyes of a Belfast Child: Life. Personal Reflections. Poems. Victoria, BC: FriesenPress, 2014.

Richardson, Brian. "Now You Are Everywhere.” Unpublished play, 2014, courtesy of the author. Microsoft Word file.

Richardson, Brian. Patterns from Snow: Poems, Patterns and Photography. Winnipeg, MB: Snacpress, 2001.

Richardson, Brian. Reflections from a Basement Window. Winnipeg, MB: The Prairie Publishing Company, 1983.

\section{Newspapers and magazines}

Slevin, Gerry. "In the Footsteps of Cusack." Treoir 17, no. 2 (1985): 16.

The Victoria Advocate

Westmeath Examiner

Winnipeg Free Press

\section{Government documents}

Statistics Canada. 2006 Census of Canada topic based tabulation Ethnic Origin (101), Age Groups (8), Sex (3) and Selected Demographic, Cultural, Labour Force, Educational and Income Characteristics (309), for the Total Population of Canada, Provinces, Territories, Census Metropolitan Areas and Census Agglomerations, 2006 Census - 20\% Sample Data. (Catalogue no. 97-564XCB2006007). Retrieved 3 August 2015 from Statistics Canada: https://www12.statcan.gc.ca/census-recensement/2006/dp-pd/tbt/Rpeng.cfm? $\mathrm{LANG}=\mathrm{E} \& \mathrm{APATH}=3 \& \mathrm{DETAIL}=1 \& \mathrm{DIM}=0 \& \mathrm{FL}=\mathrm{A} \& \mathrm{FREE}=0 \& \mathrm{GC}=$ $0 \& \mathrm{GID}=0 \& \mathrm{GK}=0 \& \mathrm{GRP}=0 \& \mathrm{PID}=97614 \& \mathrm{PRID}=0 \& \mathrm{PTYPE}=88971,97154 \& \mathrm{~S}=$ $0 \&$ SHOWALL $=0 \&$ SUB $=801 \&$ Temporal $=2006 \&$ THEME $=80 \&$ VID $=0 \&$ VNA $\underline{\mathrm{MEE}}=\& \mathrm{VNAMEF}$ 


\section{Museum materials}

Museum brochure and map. The National Wax Museum Plus. Dublin, Ireland. 11 August 2014.

Museum label, The Writers Room, National Wax Museum Plus, 11 August 2014.

Museum video. The Grand Hall of Fame. The National Wax Museum Plus. 11 August 2014.

\section{Books}

Abrams, Lynn. Oral History Theory. London and New York: Routledge, 2010.

Akenson, Donald. The Irish Diaspora: A Primer. Toronto: P.D. Meany, 1993.

Anderson, Benedict. Imagined Communities: Reflections on the Origins and Spread of Nationalism. London: Verso, 2006.

Aughey, Arthur, and Duncan Morrow, eds. Northern Ireland: Politics. London and New York: Longman, 1996.

Barber, Marilyn and Murray Watson. Invisible Immigrants: The English in Canada since 1945. Winnipeg, MB: University of Manitoba Press, 2015.

Basu, Paul. Highland Homecomings: Genealogy and Heritage Tourism in the Scottish Diaspora. London and New York: Routledge, 2007.

Basu, Paul. "Roots-tourism as Return Movements: Semantics and the Scottish Diaspora." In Emigrant Homecomings: The Return Movements of Emigrants, 1600-2000, edited by Marjory Harper, 131-150. Manchester: Manchester University Press, 2005

Bielenberg, Andrew, ed. The Irish Diaspora. London and New York: Routledge, 2013.

Bissoondath, Neil. Selling Illusions: The Cult of Multiculturalism in Canada. Toronto: Penguin Books, 1994.

Boyd, Douglas A., and Mary A. Larson, eds. Oral History and Digital Humanities: Voice, Access, and Engagement. New York: Palgrave Macmillan, 2014.

Campbell, Claire Elizabeth. Shaped by the West Wind: Nature and History in Georgian Bay. Vancouver: UBC Press, 2005.

Chilvers, Ian. The Oxford Dictionary of Art. $3^{\text {rd }}$ ed. Oxford: Oxford University Press, 2004. 
Cresswell, Tim. On the Move: Mobility in the Modern Western World. New York and London: Routledge, 2006.

Cronon, William. "The Trouble with Wilderness; or, Getting Back to the Wrong Nature." In Uncommon Ground: Rethinking the Human Place in Nature, edited by William Cronon, 69-90. New York: W.W. Norton \& Co., 1995.

Darvill, Timothy. The Concise Oxford Dictionary of Archaeology. $2^{\text {nd }}$ ed. Oxford: Oxford University Press, 2009.

Dening, Greg. Performances. Chicago: The University of Chicago Press, 1996.

Trew, Joanne Devlin. Leaving the North: Migration and Memory, Northern Ireland 1921-2011. Liverpool: Liverpool University Press, 2013.

Dowling, Martin. Traditional Music and Irish Society: Historical Perspectives. Surrey: Ashgate Publishing Ltd., 2014.

Elliott, Bruce S. Irish Migrants in the Canadas: A New Approach. Montreal and Kingston: McGill-Queen's University Press, 2004.

Fitzgerald, Patrick, and Brian Lambkin. Migration in Irish History, 1607-2007. Hampshire and New York: Palgrave Macmillan, 2008.

Foster, John Wilson. ed. Nature in Ireland: A Scientific and Cultural History. Montreal and Kingston: McGill-Queen's University Press, 1997.

Graham, Brian, ed. In Search of Ireland: A Cultural Geography. London and New York: Routledge, 1997.

Greenhill, Pauline. Ethnicity in the Mainstream: Three Studies of English Culture in Ontario. Montreal and Kingston: McGill-Queen's University Press, 1994.

Greenspan, Henry. On Listening to Holocaust Survivors: Beyond Testimony. St. Paul, MN: Paragon House, 2010.

Goffman, Erving. The Presentation of Self in Everyday Life. New York: Anchor Books, 1959.

Halbwachs, Maurice. The Collective Memory. Translated Francis J. Ditter, Jr. and Vida Yazdi Ditter. New York: Harper \& Row Colophon Books, 1980.

Hast, Dorothea E., and Stanley Scott. Music in Ireland: Experiencing Music, Expressing Culture. New York and Oxford: Oxford University Press, 2004.

Howe, Stephen. Ireland and Empire: Colonial Legacies in Irish History and Culture. Oxford: Oxford University Press, 2002. 
Iacovetta, Franca. Gatekeepers: Reshaping Immigrant Lives in Cold War Canada. Toronto: Between the Lines, 2006.

Ingold, Tim. Being Alive: Essays on Movements, Knowledge and Description. London and New York: Routledge, 2011.

Kinealy, Christine. A New History of Ireland. Stroud, Glouchestershire: Sutton Publishing Ltd., 2004.

Llewellyn, Kirstina R., Alexander Freund, and Nolan Reilly, eds. The Canadian Oral History Reader. Montreal and Kingston: McGill-Queen's University Press, 2015.

Loewen, Royden. "The Poetics of Peoplehood: Ethnicity and Religion among Canada's Mennonites." In Christianity and Ethnicity in Canada, edited by Paul Bramadat and David Seljak, 330-364. Toronto: University of Toronto Press, 2008.

Loewen, Royden and Gerald Friesen. Immigrants in Prairie Cities: Ethnic Diversity in Twentieth-Century Canada. Toronto: University of Toronto Press, 2009.

Lorenzkowski, Barbara. “The Children's War.” In Occupied St. John's: A Social History of a City at War, 1939-1945, edited by Steven High, 113-150. Montreal and Kingston: McGill-Queen's University Press, 2010.

Louter, David. Windshield Wilderness: Cars, Roads, and Nature in Washington's National Parks. Seattle: University of Washington Press, 2006.

McGowan, Mark G. The Waning of the Green: Catholics, the Irish, and Identity in Toronto, 1887-1922. Montreal and Kingston: McGill-Queen's University Press, 1999.

McIntosh, Gillian. The Force of Culture: Unionist Identities in Twentieth-Century Ireland. Cork: Cork University Press, 1999.

Nash, Linda. Inescapable Ecologies: A History of Environment, Disease, and Knowledge. Berkeley and Los Angeles: University of California Press, 2006.

O’Flynn, John. The Irishness of Irish Music. Surrey: Ashgate Publishing Ltd., 2009.

Opp, James, and John C. Walsh, eds. Placing Memory and Remembering Place in Canada. Vancouver: UBC Press, 2010.

O’Shea, Helen. The Making of Irish Traditional Music. Cork: Cork University Press, 2008.

Parr, Joy. Sensing Changes: Technologies, Environments and the Everyday. Vancouver: UBC Press, 2010. 
Plamper, Jan. The History of Emotions: An Introduction Oxford: Oxford University Press, 2015.

Portelli, Alessandro. The Death of Luigi Trastulli and Other Stories: Form and Meaning in Oral History. Albany, NY: State University of New York Press, 1991.

Reddy, William M. The Navigation of Feeling: A Framework for the History of Emotions. Cambridge: Cambridge University Press, 2001.

Regan, Paulette. Unsettling the Settler Within: Indian Residential Schools, Truth Telling, and Reconciliation in Canada. Vancouver: UBC Press, 2010.

Rushdie, Salman. Imaginary Homelands: Essays and Criticism 1981-1991. New York: Penquin Books, 1992.

Rutherford-Johnson, Tim, Michael Kennedy, and Joyce Bourne Kennedy, eds. The Oxford Dictionary of Music, $6^{\text {th }}$ ed. Oxford: Oxford University Press, 2012.

Sangster, Joan. "Telling Our Stories: Feminist Debates and the Use of Oral History.” In The Oral History Reader, edited by Robert Perks and Alistair Thomson, 87-100. London and New York: Routledge, 2005.

Schama, Simon. Landscape and Memory. New York: Vintage Books, 1995.

Scharff, Virginia. Taking the Wheel: Women and the Coming of the Motor Age. New York: Free Press, 1991.

Shaw, Philip. The Sublime. London and New York: Routledge, 2006.

Smith, Mick, Joyce Davidson, Laura Cameron, and Liz Bondi. Emotion, Place and Culture. Farnham, UK: Ashgate Publishing Ltd, 2009.

Smith, Thérèse, ed. Ancestral Imprints: Histories of Irish Traditional Music and Dance. Cork: Cork University Press, 2012.

Smyth, Gerry. Music in Irish Cultural History. Sallins, KE: Irish Academic Press, 2009.

Stern, Steve. Remembering Pinochet's Chile: On the Eve of London 1998. Durham: Duke University Press, 2004.

Stokes, Martin, ed. Ethnicity, Identity and Music: The Musical Construction of Place. Oxford and New York: Berg Publishers, 1994.

Strauss, Sarah and Benjamin S. Orlove, eds. Weather, Climate, Culture. Oxford and New York: Berg, 2003.

Taylor, Diana. The Archive and the Repertoire: Performing Cultural Memory in the Americas. Durham, NC: Duke University Press, 2003. 
Tilley, Christopher. A Phenomenology of Landscape Places, Paths, and Monuments. Oxford: Berg Publishers, 1994.

Tucker, Judith. "Brooding on Bornholm: Postmemory, Painting and Place." In Geography and Memory: Explorations in Identity, Place and Becoming, edited by Owain Jones and Joanne Garde-Hansen, 68-84. New York: Palgrave Macmillan, 2012.

Valencius, Conevery. The Health of a Country: How American Settlers Understood Themselves and Their Land. New York: Basic Books, 2002.

Vallely, Fintan. Tuned Out: Traditional Music and Identity in Northern Ireland. Cork: Cork University Press, 2008.

Webster Hollis III, Daniel. The History of Ireland. Westport, CT: Greenwood Press, 2001.

\section{Articles}

Assmann, Jan, and John Czaplicka. "Collective Memory and Cultural Identity." New German Critique 65 (Spring-Summer, 1995): 125-133.

Bramadat, Paul A. "Toward a New Politics of Authenticity: Ethno-Cultural Representation in Theory and Practice." Canadian Ethnic Studies 37, no. 1 (2005): 1-20.

Bryan, Dominic. "Parade Disputes and the Peace Process." Peace Review 13, no. 1 (2001): 43-49.

Clary-Lemon, Jennifer. “'We're not ethnic, we're Irish!': Oral Histories and the Discursive Construction of Immigrant Identity." Discourse Society 21, no. 1 (2010): 5-25.

Conzen, Kathleen Neils, David A. Gerber, Ewa Morawska, George E. Pozzetta, and Rudolph J. Vecoli. "The Invention of Ethnicity: A Perspective from the U.S.A." Journal of American Ethnic History 29 (Fall, 1992): 3-41.

Corbett, Katharine T., and Howard S. Miller, "A Shared Inquiry into Shared Inquiry." The Public Historian 28, no. 1 (Winter, 2006): 15-38.

Cruikshank, Julie. "Claiming Legitimacy: Prophecy Narratives from Northern Aboriginal Women." American Indian Quarterly 18, no. 2 (Spring, 1994): 147-167.

Davidson, Joyce, and Christine Milligan. "Embodying Emotion Sensing Space: Introducing emotional geographies." Social \& Cultural Geography 5, no. 4 (December, 2004): 523-524. 
Davis, Leith. Music, Postcolonialism, and Gender: The Construction of Irish National Identity, 1724-1874. Notre Dame, IN: University of Notre Dame Press, 2006.

deMarrais, Kathleen, and Kit Tisdale, "What Happens When Researchers Inquire Into Difficult Emotions?: Reflections on Studying Women's Anger Through Qualitative Interview." Educational Psychologist 37, no. 2 (2002): 115-123.

Dowling, Martin W. "Confusing Culture and Politics: Ulster Scots Culture and Music." New Hibernia Review 11, no. 3 (Autumn, 2007): 51-80.

Field, Sean. "Beyond 'Healing': Trauma, Oral History and Regeneration." Oral History 34, no. 1 (Spring 2006): 31-42.

Freund, Alexander. “'Confessing Animals': Towards a Longue Durée History of the Oral History Interview." The Oral History Review 41, no. 1 (2014): 1-26.

Gardner, Peter Robert. "Unionism, Loyalism, and the Ulster-Scots Ethnolinguistic 'Revival'." Studies in Ethnicity and Nationalism 15, no. 1 (2015): 4-25.

Gilmartin, Mary. "The changing landscape of Irish migration, 2000-2012." Working Paper, National Institute for Regional and Spatial Analysis Working Paper Series, National University of Ireland, Maynooth, October, 2012.

High, Steven. "Sharing Authority: An Introduction." Journal of Canadian Studies/Revue d'études canadiennes 43, no. 1 (Winter, 2009): 12-34.

Hirsch, Marianne. "The Generation of Postmemory." Poetics Today 29, no. 1 (Spring, 2008): 103-128.

Jamil, Hikmet, Sylia C. Nassar-McMilan, and Richard G. Lambert, "Immigration and Attendant Psychological Sequelae: A Comparison of Three Waves of Iraqi Immigrants," American Journal of Orthopsychiatry 77, no. 2 (2007): 199-205.

Kaul, Adam. "Music on the edge: Busking at the Cliffs of Moher and the commodification of a musical landscape." Tourist Studies 14, no. 1 (2014): 3047.

Kerr, Daniel. “'We Know What the Problem Is': Using Oral History to Develop a Collaborative Analysis of Homelessness from the Bottom Up." The Oral History Review 30, no. 1 (2003): 27-45.

Leonard, Madeleine, and Martina McKnight. "Traditions and Transitions: Teenagers' perceptions of parading in Belfast." Children's Geographies (2013): 1-15.

Leonard, Marion. "Performing Identity: Music and Dance in the Irish Communities of Coventry and Liverpool." Social \& Cultural Geography 6, no. 4 (August, 2005): 515-529. 
Lukashok, Alvin K., and Kevin Lynch. "Some Childhood Memories of the City." Journal of the American Institute of Planners 22, no. 3 (1956): 142-152.

Mac Éinrí, Piaras, and Tina O'Toole. "Editors' Introduction: New Approaches to Irish Migration." Éire-Ireland 47, no. 1\&2 (Spring/Summer, 2012): 5-18.

McCann, May. "Music and Politics in Ireland: The Specificity of the Folk Revival in Belfast." British Journal of Ethnomusicology 4 (1995): 51-75.

McLoone, Martin. "Punk Music in Northern Ireland: The Political Power of 'What Might Have Been'.” Irish Studies Review 12, no. 1 (2004): 29-38.

Nash, Catherine. "Local Histories in Northern Ireland." History Workshop Journal 60 (Autumn, 2005): 45-68.

Parr, Joy. "Notes for a More Sensuous History of Twentieth-Century Canada: The Timely, the Tacit and the Material Body." The Canadian Historical Review 82, no. 4 (December 2001): 720-745.

Parr, Joy, Jon Van der Veen, and Jessica van Horssen. "The Practice of History Shared across Differences: Needs, Technologies, and Ways of Knowing in the Megaprojects New Media Project." Journal of Canadian Studies/Revue d'études canadiennes 43, no. 1 (Winter 2009): 35-56.

Pierce, David. "Cultural Nationalism and the Irish Literary Revival." International Journal of English Studies 2, no. 2 (2002): 1-22.

Portelli, Alessandro. "The Peculiarities of Oral History." History Workshop Journal 12, no. 1 (1981): 96-107.

Portelli, Alessandro. "A Dialogical Relationship: An Approach to Oral History." Expressions Annual 14 (2005). Accessed 2 July 2015. http://www.swaraj.org/shikshantar/expressions_portelli.pdf,

Rolston, Bill. "'This is not a rebel song': The Irish Conflict and Popular Music." Race \& Class 42, no. 3 (2001): 49-67.

Rosenwein, Barbara H. "Worrying about Emotions in History." The American Historical Review 107, no. 3 (June 2002): 821-845.

Shopes, Linda. "Commentary: Sharing Authority." The Oral History Review 30, no. 1 (2003): 103-110.

Shopes, Linda. "Insights and Oversights': Reflections on the Documentary Tradition and the Theoretical Turn in Oral History." The Oral History Review 41, no. 2 (2014): 257-268. 
Smith, Angèle. "Fitting into a New Place: Irish Immigrant Experiences in Shaping a Canadian Landscape." International Journal of Historical Archaeology 8, no. 3 (September, 2004): 217-230.

Stearns. Peter N., and Carol Z. Stearns, "Emotionology: Clarifying the History of Emotions and Emotional Standards." The American Historical Review 90, no. 4 (October 1985): 813-836.

Suigman, Pamela. "Life is Sweet': Vulnerability and Composure in the Wartime Narratives of Japanese Canadians." Journal of Canadian Studies/Revue d'études canadiennes 43, no. 1 (Winter, 2009): 186-218.

Sugiman, Pamela. “'These Feelings that Fill my Heart': Japanese Canadian Women's Memories of Internment." Oral History 34, no. 2 (Autumn 2006): 69-84.

Thomson, Alistair. "Sharing Authority: Oral History and the Collaborative Process." The Oral History Review 30, no. 1 (2003): 23-26.

Thoroski, Cynthia, and Pauline Greenhill. "Putting a price on culture: ethnic organisations, volunteers, and the marketing of multicultural festivals." Ethnologies 23, no. 1 (2001): 189-209.

Trigger, Rosalyn. "Irish Politics on Parade: The Clergy, National Societies, and St. Patrick's Day Processions in Nineteenth-century Montreal and Toronto." Histoire Sociale/Social History 37, no. 74 (November, 2004): 159-199.

Walsh, Michael J. K. "Mama’s Boys, Celtus, and the Troubles in Northern Ireland.” Rock Music Studies 2, no. 1 (2015): 46-60.

von Plato, Alexander, and Edith Burley. "Contemporary Witnesses and the Historical Profession: Remembrance, Communicative Transmission, and Collective Memory in Qualitative History." Oral History Forum d'histoire orale 29 (2009): $1-27$.

Yow, Valerie. "Ethics and Interpersonal Relationships in Oral History Research." The Oral History Review 22, no. 1 (Summer, 1995): 51-66.

Zembrzycki, Stacey. "Sharing Authority with Baba." Journal of Canadian Studies/Revue d'études canadiennes 43, no. 1 (Winter, 2009): 219-238.

\section{Theses}

Rowe, Allan. "Prairie Shamrock: Irish Settlement and Identity in Western Canada, 18701930s." PhD diss., University of Alberta, 2008. 


\section{Website sources}

Arts Council of Ireland. "Who we are." Accessed 06 August 2015. http://www.artscouncil.ie/about/Who-we-are/.

Canadian Climate Normals 1981-2010 Station Data. "Temperature and Precipitation Chart for 1981 to 2010 Canadian Climate Normals: Winnipeg Richardson Int'1 A.” Accessed 05 August 2015. http://climate.weather.gc.ca/climate normals/results 19812010 e.html?stnID= 3698\&lang=e\&amp;StationName=winnipeg\&amp;SearchType=Contains\&amp; $\underline{\operatorname{stnNameSubmit}=\text { go } \& \mathrm{dCode}=1 \& \operatorname{dispBack}=1}$

Devor, Teresa. “'Living Weather' and Survival: Learning Local Weather Ecology in the Maritimes and Newfoundland, 1780-1920.” Accessed 4 August 2015. http://www.historicalclimatology.com/teresa-devor-living-weather.html.

Folklorama. "Find a Pavilion." Accessed 06 August 2015. http://www.folklorama.ca/find-a-pavilion.

Parr, Joy, Jon Van der Veen, and Jessica van Horssen, "Megaprojects New Media." Accessed 05 August 2015. http://megaprojects.uwo.ca/.

The Irish Association of Manitoba. Accessed 5 August 2015. http://www.irishassociation.ca/.

Tourist Information Dublin. "The National Wax Museum, Dublin.” Accessed 06 August 2015. http://www.tourist-information-dublin.co.uk/the-national-waxmuseum.htm.

Shoebridge, Paul, and Michael Simons. "Welcome to Pine Point." Accessed 05 August 2015. http://pinepoint.nfb.ca/\#/pinepoint.

"Winnipeg deep freeze as cold as uninhabited planet." CBC News. 31 December 2013. http://www.cbc.ca/news/canada/manitoba/winnipeg-deep-freeze-as-cold-asuninhabited-planet-1.2479967.

Zembrzycki, Stacey. “According to Baba: A Collaborative Oral History of Sudbury's Ukrainian Community." Last modified 26 October 2014.

http://www.sudburyukrainians.ca/. 


\section{Appendix I: Interviewee Reference Chart}

\begin{tabular}{|l|l|l|l|}
\hline Name & Born & Hometown in Ireland & Moved to Winnipeg \\
\hline Eileen Baxter & 1935 & Belfast, Co. Antrim & 1975 \\
\hline Joe Campbell & 1934 & Dublin, Co. Dublin & 1972 \\
\hline Mary Campbell & 1944 & Nenagh, Co. Tipperary & 1973 \\
\hline Shirley Foamete & 1971 & Cork, Co. Cork & 2012 \\
\hline Patrick Gannon & 1947 & Cootehill, Co. Cavan & 1957 \\
\hline Greg McVicker & 1970 & Belfast, Co. Antrim & 1985 \\
\hline Tom Naughten & 1954 & Dublin, Co. Dublin & 1990 \\
\hline Brian Richardson & 1945 & $\begin{array}{l}\text { Dun Laoghaire, Co. } \\
\text { Dublin }\end{array}$ & 1970 \\
\hline Maureen Taggart & 1946 & $\begin{array}{l}\text { Near Cappawhite, Co. } \\
\text { Tipperary }\end{array}$ & 1971 \\
\hline Catriona Younger & 1951 & Cootehill, Co. Cavan & 1957 \\
\hline
\end{tabular}




\section{Appendix II: Ethics Clearance Forms}

Carleton

Canada's Capital University
Carleton University

Research Ethics Office

Research Ethics Board

511 Tory, 1125 Colonel By Drive

Ottawa, ON K1S 5B6 Canada

Tel: 613-520-2517, ethics@carleton.ca

\section{Ethics Clearance Form - Clearance Renewal}

This is to certify that the Carleton University Research Ethics Board has examined the application for ethical clearance. The REB found the research project to meet appropriate ethical standards as outlined in the Tri-Council Policy Statement: Ethical Conduct for Research Involving Human, 2nd edition, and the Carleton University Policies and Procedures for the Ethical Conduct of Research.

Original Date of Clearance: March 28, 2014

Renewal Date of Clearance: April 29, 2015

Researcher: Kathryn Boschmann (Student Research: Master's Student)

Department: Faculty of Arts and Social ScienceslHistory (Department of)

University: Carleton University

Research Supervisor (if applicable): Joanna Dean

Project Number: 101044

Alternate File Number (if applicable):

Project Title: Being Irish in a Prairie City: The migration experience and search for home among Irish Canadians in Winnipeg, 1950-2014

Funder (if applicable):

Clearance Expires: May 31, 2016

All researchers are governed by the following conditions:

Annual Status Report: You are required to submit an Annual Status Report to either renew clearance or close the file. Failure to submit the Annual Status Report will result in the immediate suspension of the project. Funded projects will have accounts suspended until the report is submitted and approved.

Changes to the project: Any changes to the project must be submitted to the Carleton University Research Ethics Board for approval. All changes must be approved prior to the continuance of the research.

Adverse events: Should a participant suffer adversely from their participation in the project you are required to report the matter to the Carleton University Research Ethics Board. You must submit a written record of the event and indicate what steps you have taken to resolve the situation.

Suspension or termination of clearance: Failure to conduct the research in accordance with the principles of the Tri-Council Policy Statement: Ethical Conduct for Research Involving Humans, 2nd edition and the Carleton University Policies and Procedures for the Ethical Conduct of Research may result in the suspension or termination of the research project.

Louise Heslop

Chair, Carleton University Research Ethics Board
Andy Adler

Vice-Chair, Carleton University Research Ethics Board 


\section{Appendix III: Examples of interview questions}

Can you tell me about your life in Ireland (family, childhood, school, etc.)?

Why did you leave Ireland?

How did you come to settle in Winnipeg? Do you like Winnipeg? Why or why not?

What was it like to move from a relatively small island to the Canadian prairies?

Did you involve yourself in any Irish associations or cultural groups in Winnipeg (The Irish Association of Manitoba, Comhaltas, the Tara Players, etc.)? Why or why not?

Do you think the politics of Ireland have transferred to Winnipeg? Why or why not?

Have you participated in cultural festivals or holidays like Folklorama, Winnipeg Irish Festival, or St. Patrick's Day celebrations? Why or why not? What do you think about these kinds of events?

Have you ever been participated in Irish cultural activities (traditional music, theatrical performances, etc.)? Was this something you pursued in Ireland? If so, did you continue these activities in Canada and why was this important to you? If not, when did you start participating in these activities and why?

What do you think is the role of Irish cultural activities?

Did your parents or grandparents think it was important to have a sense of Irish heritage?

If applicable: Do your children identify as Irish? If so, how do they express this? Was this something you thought was important? Why or why not?

Do you visit Ireland? Was this something you found important to do? If so, why? What was it like to go back?

Have you done any family history?

Where is home for you? 